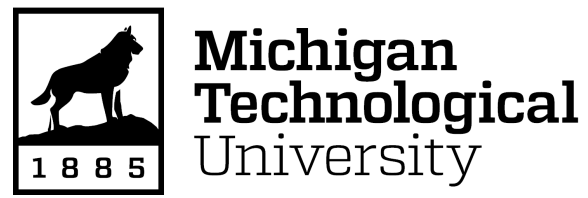

Michigan Technological University Digital Commons @ Michigan Tech

Dissertations, Master's Theses and Master's Reports

2019

\title{
A Characterization of Colorectal Carcinoma In Patients From The Upper Peninsula of Michigan
}

Cathy Bammert

Michigan Technological University, cebammer@mtu.edu

Copyright 2019 Cathy Bammert

\section{Recommended Citation}

Bammert, Cathy, "A Characterization of Colorectal Carcinoma In Patients From The Upper Peninsula of Michigan", Open Access Dissertation, Michigan Technological University, 2019.

https://doi.org/10.37099/mtu.dc.etdr/925

Follow this and additional works at: https://digitalcommons.mtu.edu/etdr

Part of the Medicine and Health Sciences Commons 


\title{
A CHARACTERIZATION OF COLORECTAL CARCINOMA IN PATIENTS FROM THE UPPER PENINSULA OF MICHIGAN
}

\author{
By \\ Catherine E. Bammert \\ A DISSERTATION \\ Submitted in partial fulfillment of the requirements for the degree of \\ DOCTOR OF PHILOSOPHY \\ In Biological Sciences
}

MICHIGAN TECHNOLOGICAL UNIVERSITY

2019

(C) 2019 Catherine E. Bammert 
This dissertation has been approved in partial fulfillment of the requirements for the Degree of DOCTOR OF PHILOSOPHY in Biological Sciences.

Department of Biological Sciences

$\begin{aligned} \text { Dissertation Co-Advisor: } & \text { Lanrong Bi } \\ \text { Dissertation Co-Advisor: } & \text { Jingfang Ju } \\ \text { Committee Member: } & \text { Chandrashekhar Joshi } \\ \text { Committee Member: } & \text { Xiaohu (Mark) Tang } \\ \text { Committee Member: } & \text { Feng Zhao } \\ & \\ \text { Department Chair: } & \text { Chandrashekhar Joshi }\end{aligned}$




\section{Contents}

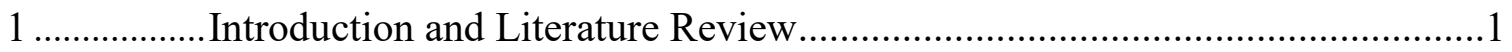

1.1 Genes and Molecular Pathways Involved in Tumorigenesis ...........................1

1.2 Heterogeneity of Colorectal Cancer ................................................................

1.3 The Role of Programmed Cell Death Ligand (PD-L1) in Colorectal Cancer ..4

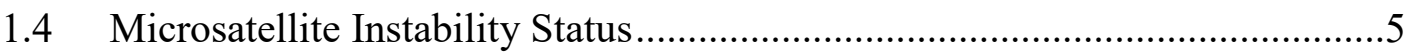

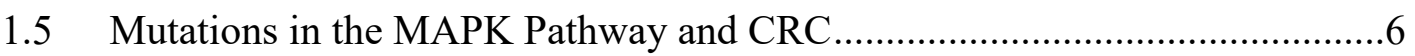

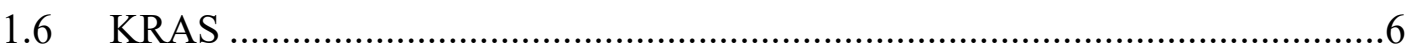

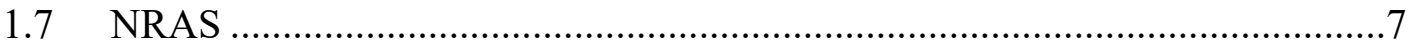

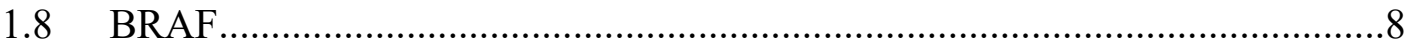

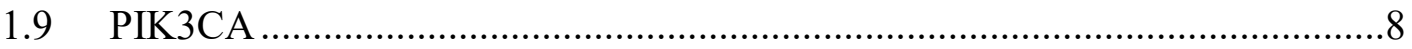

1.10 Primary Tumor Location and Prognosis .......................................................

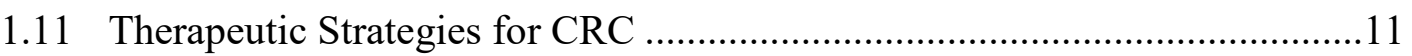

1.12 Colorectal Cancer Mutation Testing ..............................................................13

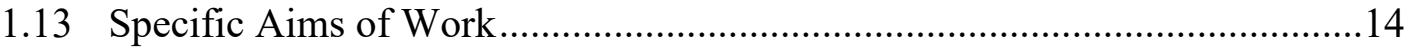

2 A Retrospective Population-based Study of Colorectal Cancer in the Upper

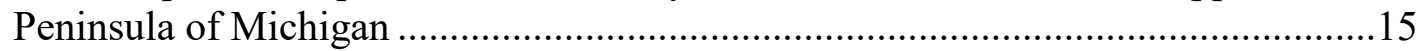

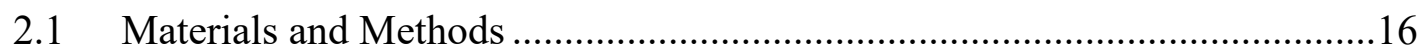

2.1.1 Study Design and Patient Population..............................................16

2.1.2 Inclusion and Exclusion Criteria......................................................

2.1.3 Histological Classification of Colon Cancer........................................17

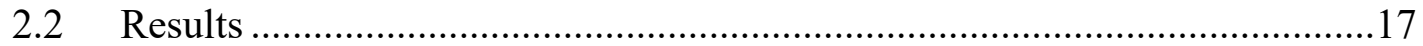

2.2.1 Patient Demographics ................................................................. 17

2.2.2 Distribution of Primary Tumors..........................................................17

2.2.3 Histologic Grading and Staging by Tumor Site................................18

2.2.4 Clinical Rationale for Colonoscopy Referral.....................................19

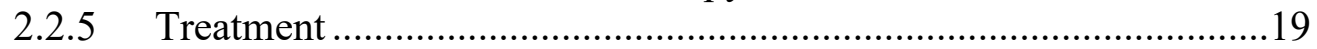

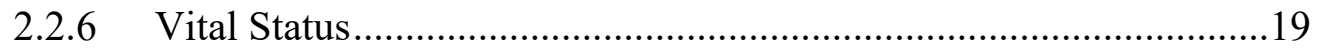

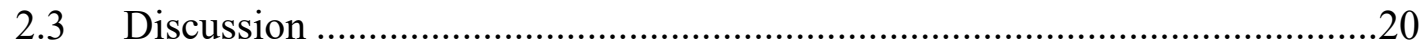

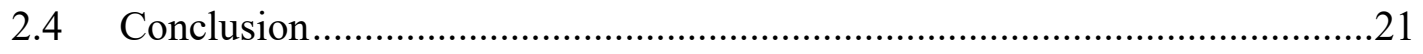

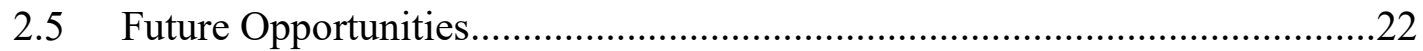


3 Colorectal Cancer in the Upper Peninsula of Michigan: A Population-based Study characterizing molecular mutations and clinical attributes........................................23

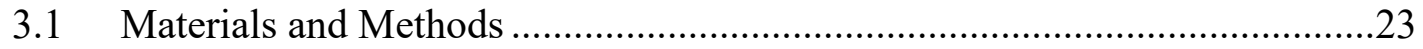

3.1.1 Study Design and Patient Population.................................................23

3.1.2 Tissue Selection and DNA extraction...........................................24

3.1.3 K-RAS Kirsten Rat Sarcoma Viral Oncogene Homolog (KRAS) Mutation Analysis

3.1.4 B-RAF Proto-oncogene (BRAF) and Neuroblastoma RAS Viral Oncogene Homolog (NRAS) Mutation Analysis .........................26

3.1.5 Phosphatidylinositol-4,5-Bisphosphate 3-Kinase, Catalytic Subunit Alpha (PIK3CA) Mutation Analysis..........................................26

3.1.6 Immunohistochemical Assessment of DNA Mismatch Repair

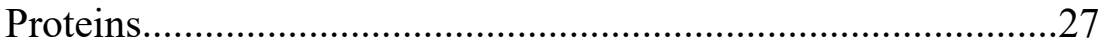

3.1.7 Immunohistochemical Assessment of PD-L1 Expression................27

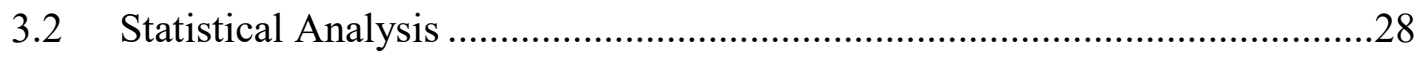

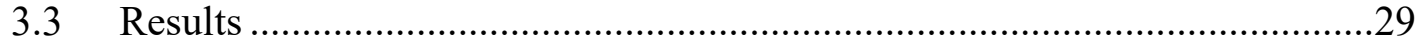

3.3.1 Patient Demographics ...................................................................29

3.3.2 Distribution of Primary Tumors by Anatomic Site...........................29

3.3.3 Histologic Grading and Staging by Anatomic Site...........................29

3.3.4 KRAS Mutation Status by Tumor Location .......................................30

3.3.5 BRAF Mutation Status by Anatomic Site ...........................................31

3.3.6 NRAS Mutation Status by Anatomic Site ………….........................32

3.3.7 PIK3CA Mutation Status by Anatomic Site ........................................32

3.3.8 Concomitant Mutations by Anatomic Site..........................................33

3.3.9 Immunohistochemical Analysis of DNA Mismatch Repair Proteins.................................................................................

3.3.10 Immunohistochemical Analysis of PD-L1 Expression........................34

3.3.11 Characterization of Synchronous Malignancies .................................34

3.3.12 Characterization of Recurring Malignancies .......................................35

3.3.13 Characterization of Chemoresistant Malignancies .............................36

3.3.14 Characterization of Malignancies In Which No Mutations Were

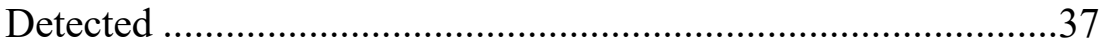

3.3.15 Characterization of Patients with Cancer-related Cause of Death....37

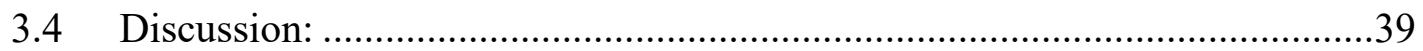

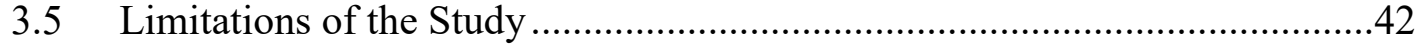

3.6 Conclusion............................................................................................

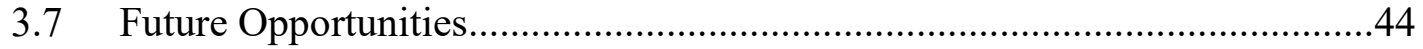

4

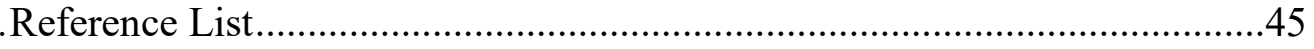

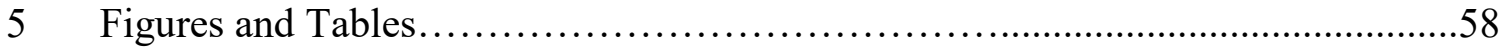


Figure A.1 Incidence of CRC by County in the UP of Michigan.........................58

Figure A.2. Percent of CRC cases with regional or distant metastasis...........58

Figure A.3. Anatomic distribution of primary malignancies CRC in cohort......60

Figure A.4. AJCC staging by anatomic site of primary malignancy in patient cohort..........................................................6 61

Figure A.5. Distribution of primary malignancies in 120 patient cohort..........63

Figure A.6. Distribution of Primary malignancies in the proximal vs distal colon

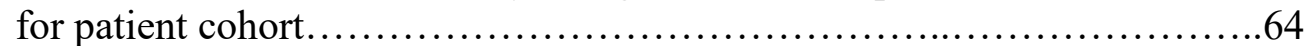

Figure A.7. MMR IHC stain depicting intact MMR proteins in colon resection......................................................87

Figure A.8. MMR IHC stain depicting intact MMR proteins in $\mathrm{mCRC}$ in lymph

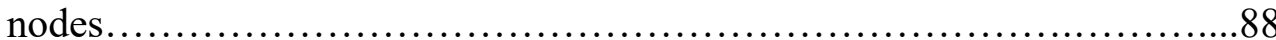

Figure A.9. MMR IHC stain depicting deficient MMR proteins in colon

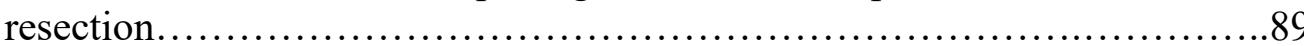

Figure A.10. MMR IHC stain depicting deficient MMR proteins in $\mathrm{mCRC}$ in lymph nodes.................................................... 90

Figure A.11. IHC depicting negative PD-L1 expression in colon resection and matched mCRC in lymph nod.......................................99

Figure A.12. IHC depicting positive PD-L1 expression in colon resection and matched mCRC in lymph node..................................... 100

Table A.1. Patient demographics and anatomic distribution of primary malignancy for cohort.

Table A.2. Classification of colonoscopies and mechanism for detection of CRC

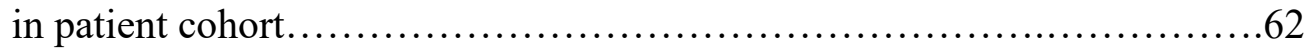

Table A.3. AJCC Staging by primary site for 120 patient cohort................65

Table A.4. Correlation of KRAS G12x targeted region mutations with clinicopathological data for patient cohort............................66

Table A.5. Correlation of KRAS G13x targeted region mutations with clinicopathological data for patient cohort............................68

Table A.6. Correlation of BRAF V600E mutations with clinicopathological data for patient cohort................................................ 70

Table A.7. Correlation of NRAS targeted region mutations with clinicopathological data for patient cohort.............................72

Table A.8. Correlation of PIK3CA targeted region mutations with clinicopathological data for patient cohort............................73

Table A.9. Diversity of concomitant mutations and clinicopathological features for patient cohort .75

Table A.10 Characterization of malignancies with intact DNA MMR repair proteins and clinicopathological features of patient cohort.................91

Table A.11. Characterization of malignancies with deficient DNA MMR demonstrating a loss of MLH1/PMS2 proteins........................97

Table A.12. Characterization of malignancies with deficient DNA MMR demonstrating a loss of one DNA repair protein.........................98

Table A.13. Characterization of PD-L1 expression in patient cohort. .101 
Table A.14. Diversity of mutations and clinicopathological features in patients with synchronous malignancies......................................103

Table A.15. Diversity of mutations and clinicopathological features of patients with recurrent colorectal cancer...........................................109

Table A.16. Characterization of chemoresistant malignancies..................116

Table A.17. Clinicopathological features of malignancies in which no mutations were detected....................................................... 124

Table A.18. Clinicopathological Features of Patients Who Died From CancerRelated Causes....................................................... 126

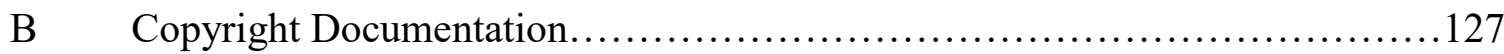




\section{List of figures}

Figure A.1. Incidence of CRC by county in the UP of Michigan.....................................58

Figure A.2. Percent of CRC cases with regional or distant metastasis..................58

Figure A.3. Anatomic distribution of primary malignancies CRC in cohort.............60

Figure A.4. AJCC staging by anatomic site of primary malignancy in patient cohort...................................................................61

Figure A.5. Distribution of primary malignancies in 120 patient cohort.................63

Figure A.6. Distribution of Primary malignancies in the proximal vs distal colon for patient cohort.......................................................... 64

Figure A.7. MMR IHC stain depicting intact MMR proteins in colon resection..........87

Figure A.8. MMR IHC stain depicting intact MMR proteins in mCRC in lymph nodes..88

Figure A.9. MMR IHC stain depicting deficient MMR proteins in colon resection.......89

Figure A.10. MMR IHC stain depicting deficient MMR proteins in mCRC in lymph nodes............................................................. 90

Figure A.11. IHC depicting negative PD-L1 expression in colon resection and matched mCRC in lymph node...............................................99

Figure A.12. IHC depicting positive PD-L1 expression in colon resection and matched mCRC in lymph node............................................. 100 


\section{List of tables}

Table A.1. Patient demographics and anatomic distribution of primary malignancy for cohort.....

Table A.2. Classification of colonoscopies and mechanism for detection of CRC in patient cohort.

Table A.3. AJCC Staging by primary site for 120 patient cohort

Table A.4. Correlation of KRAS G12x targeted region mutations with clinicopathological data for patient cohort............................................66

Table A.5. Correlation of KRAS G13x targeted region mutations with clinicopathological data for patient cohort. .68

Table A.6. Correlation of BRAF V600E mutations with clinicopathological data for patient cohort..................................................... 70

Table A.7. Correlation of NRAS targeted region mutations with clinicopathological data for patient cohort.

Table A.8. Correlation of PIK3CA targeted region mutations with clinicopathological data for patient cohort. .73

Table A.9. Diversity of concomitant mutations and clinicopathological features for patient cohort

Table A.10 Characterization of malignancies with intact DNA MMR repair proteins and clinicopathological features of patient cohort.........................91

Table A.11. Characterization of malignancies with deficient DNA MMR demonstrating a loss of MLH1/PMS2 proteins

Table A.12. Characterization of malignancies with deficient DNA MMR demonstrating a loss of one DNA repair protein.

Table A.13. Characterization of PD-L1 expression in patient cohort.

Table A.14. Diversity of mutations and clinicopathological features in patients with synchronous malignancies.

Table A.15. Diversity of mutations and clinicopathological features of patients with recurrent colorectal cancer.

Table A.16. Characterization of chemoresistant malignancies .116 
Table A.17. Clinicopathological features of malignancies in which no mutations were detected............................................................ 124

Table A.18. Clinicopathological Features of Patients Who Died From Cancer-Related

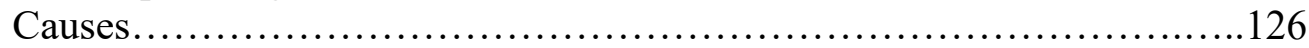




\section{Acknowledgements}

No one earns a doctorate degree on their own, and I am tremendously grateful to everyone who supported me during this incredible journey.

To my committee and everyone who mentored me along the way: Thank you for sharing your expertise, wisdom and guidance. Lanrong, thank you for being my advisor and taking a chance on this non-traditional graduate student. I will forever be grateful for your support.

To my husband, Dave: Thank you for the beautiful life that we built together- it's more than I ever dreamed possible. Because of you, I dare to dream big and act boldly to make my dreams a reality.

To my children, Anna and Jon: Thank you for your unconditional love and for always believing in me. You are, without a doubt, the best thing that ever happened in my life and will always be my greatest contribution to the world! To Guy and Jess: I'm so lucky to be your "second mom"! Thank you for the love, support and encouragement you freely share with our family.

To my parents, George and Char, and Ralph and Mary Ann: Thank you for teaching me the value of family, hard work, integrity and perseverance. Dad, I remember how sincere you were when you told me to be sure I stay in school and graduate. I wrote my letter of intent for grad school when I came home for your funeral. I know both of my fathers will be watching from heaven as this first- generation college student walks across the stage to accept her doctorate degree. I hope I've made you proud- I'll be thinking of you.

To Nancy and Neil (and the L family): Thank you for supporting my work and for being a source of pure inspiration and positive energy. You've taught me the value of partnerships and the strength that comes from living with purpose.

To my family at UPHS, MDA and co-PI's: Thank you for your support and partnership. I am so fortunate to be a part of such amazing teams! Suzanne, thanks for ensuring that I had the information to make this project as impactful as possible.

To Linda and Peter: Thank you for recognizing my potential, giving me the opportunity pursue my teaching passion and ensuring I have the resources to succeed. I am forever grateful for your friendship and support. Teresa- thank you for your support and friendship!

To Blue: I am so grateful for the life and love you shared with me. You were a loyal study partner and my best friend. Because of you, I passed my Boards and earned my Master's Degree. I'm looking forward to meeting you at the Rainbow Bridge- I know you're waiting for me. 


\section{Abstract}

As the third most commonly diagnosed malignancy and second leading cause of cancer-related death, colorectal cancer remains a major global healthcare concern. Despite numerous studies to elucidate the mutations involved in tumorigenesis and assist with the prognostic stratification of patients, individual outcomes and therapeutic responses remain unpredictable. In this study, we performed a retrospective analysis of the clinical and pathological features of colorectal cancers diagnosed in the Upper Peninsula of Michigan. We then characterized the frequency and diversity of six molecular markers (MMR, BRAF, NRAS, KRAS, PIK3CA, PD-L1) in matched samples belonging to 120 patients in our cohort and correlated the findings with cancer registry data.

PCR-based assays were performed to identify point mutations in the RAS, RAF and PIK3CA pathways using zinc formalin-fixed, paraffin-embedded blocks belonging to the patients in our cohort. Additionally, immunohistochemical stains were prepared to assess DNA mismatch repair protein expression and PD-L1 status in the tumor cells. Individual mutations were correlated with the clinical -pathological features of CRC in patients. We noted a higher frequency of primary tumors arising in the proximal colon, as well as a potential prognostic value in KRAS and PIK3CA mutation testing. We believe this is the first population-based study to characterize and correlate mutations with clinicopathological variables in colorectal cancer patients from the Upper Peninsula of Michigan. The findings presented here provide additional insight regarding the tumor 
microenvironment at various stages of disease and may lead to more effective patient management strategies as well as the development of new companion diagnostics. 


\section{Introduction and Literature Review}

Although colorectal cancer (CRC) continues to be extensively studied, it remains the third most commonly diagnosed malignancy and second leading cause of cancerrelated death in the world ${ }^{1,2}$. In 2019, CRC is projected to account for $8.3 \%$ of all new cancer diagnoses and approximately 150,000 new diagnoses this year ${ }^{2}$. The estimated five- year relative survival rate for CRC patients is approximately $64 \%$, however, overall survival rates vary significantly depending on a number of factors, including the histological stage and grade of the tumor at the time of diagnosis, the comorbidities of the patient and the chemosensitiviy of the tumor cells ${ }^{2,3}$.

\subsection{Genes and Molecular Pathways Involved in Tumorigenesis}

The genes and signaling pathways involved in CRC tumorigenesis have been well documented and include WNT/APC/ $\beta$-Catenin, MAPK, PI3K/AKT/mTOR, TGF $\beta$, and TP53 ${ }^{4,5,6}$. These pathways are responsible for regulating normal cell growth, cellular differentiation, proliferation and survival within the colonic crypts. Additionally, each pathway confers biological properties that maintain the composition of the extracellular matrix. The WNT pathway produces proteins that maintain homeostasis of the stem cell niche within the intestinal epithelium and regulate angiogenesis as well as the remodeling of existing vasculature ${ }^{6,7,8}$. The MAPK signaling cascade regulates cell migration and apoptosis ${ }^{9}$. The PI3K/ AKT pathway controls cytoskeletal rearrangement, protein translation and cell survival ${ }^{10}$. 
Phenotypically, there are three molecular pathways involved in colorectal carcinogenesis, including the chromosomal instability pathway (CIN), the $\mathrm{CpG}$ Island methylator phenotype (CIMP), and the microsatellite instability pathway (MSI). These pathways have unique characteristics but all result from the accumulation of genetic and epigenetic changes that facilitate the malignant transformation of the colonic epithelium.

Additionally, the development of neoplastic precursor lesions, such as adenomas or serrated polyps, proceed the formation of malignant lesions ${ }^{11,12,13,14}$.

The CIN pathway is associated with approximately $70 \%$ of sporadic CRCs and is characterized by large structural chromosomal changes that may include gains, losses, insertions or deletions and result in aneusomy ${ }^{8,13}$. In CRC, truncating mutations in the Adenomatous Polyposis Coli (APC) tumor suppressor gene result in the activation of the Wnt pathway which initiates tumorigenesis. Dysregulation of Wnt pathway results in chromosomal instability and the acquisition of KRAS mutations as carcinogenesis $\operatorname{progresses}^{8,14,15}$.

The microsatellite instability pathway results from defects in the DNA mismatch repair (MMR) system and is associated with approximately $15 \%$ of sporadic $\mathrm{CRC}^{8,15}$. DNA mismatch repair proteins are normally expressed by proliferating cells and correct base substitution mismatches and abnormal insertion-deletion loops arising in repetitive DNA sequences known as microsatellites ${ }^{16}$. Hypermethylation of mismatch repair (MMR) genes results in a loss of function of the MMR machinery and accelerate the accumulation of mutations, especially within repetitive, microsatellite regions ${ }^{8,15}$. 
Consequently, nucleotide expansions occurring in the exons of genes result in frameshift mutations and mutations in tumor-related genes ${ }^{14}$.

Microsatellite instability may also be inherited as a germline mutation via Lynch Syndrome. Individuals with Lynch syndrome inherit a mutant MMR gene and consequently have somatic cells that contain one normal and one non-functioning MMR gene. During tumorigenesis, the normal gene MMR gene may become mutated or epigenetically silenced, resulting in the loss of function of the MMR machinery and acquisition of microsatellite instability in the malignant cells ${ }^{8,14,15}$.

The $\mathrm{CpG}$ Island Methylator Phenotype (CIMP) pathway is characterized by global hypermethylation of $\mathrm{CpG}$ island promoters that result in the epigenetic silencing of MMR proteins and tumor suppressor genes ${ }^{8,14,15,17}$. CIMP is believed to be an underlying factor in MSI, since the latter is often associated with promoter methylation of the MLH1 MMR gene ${ }^{18}$. CIMP tumors tend to be hypermutated, with many demonstrating concomitant BRAF mutations ${ }^{8,15,18}$.

\subsection{Heterogeneity of Colorectal Cancer}

A plethora of research has been performed to elucidate the heterogeneity of CRC, a hallmark feature of this malignancy. CRC tumors are comprised of a highly diverse populations of cells, including malignant differentiated colonic cells, colon cancer stem cells, fibroblasts, immune cells and endothelial cells, each interacting with its neighbors through cell signaling proteins and growth factors in the microenvironment ${ }^{19}$. Mutations are believed to be sequentially acquired as a result of genomic instability and contribute 
to the overall genetic diversity of the tumor ${ }^{20,21}$. The protective tumor microenvironment facilitates tumor development and progression by supporting angiogenesis, epithelial-tomesenchyme transition and adaptive immunity ${ }^{22,23}$.

\subsection{The Role of Programmed Cell Death Ligand (PD-L1) in Colorectal Cancer}

Programmed cell death ligand 1 (PD-L1) is a transmembrane protein that modulates the immune system by binding to receptors on T-cell lymphocytes and antigen- presenting cells, thereby inhibiting immune responses ${ }^{24,25,32,33}$. PD-L1 may also be located on the surface of malignant cells and tumor-infiltrating immune cells (TIC) within the tumor microenvironment ${ }^{5}$. Increased PD-L1 expression on tumor cells may contribute to T-cell "exhaustion" and suppression of the immune system within the tumor. Increased expression of PD-1 is associated with a poor prognosis in many malignancies, including melanoma, esophageal, gastric, hepatocellular and urothelial carcinomas, and is believed to be associated with tumor invasion in $\mathrm{CRC}$, although this has not been fully elucidated ${ }^{24,25,32,33}$.

IN CRC, PD-L1 expression has not been shown to occur in a higher frequency in either gender ${ }^{26}$. Increased PD-L1 expression and BRAF mutations with microsatellite instability have been associated with a poor prognosis. PD-L1 expression analyses might be useful in identifying patients who'd benefit from PD-L1 immunotherapies ${ }^{27}$. 


\subsection{Microsatellite Instability Status}

The mechanisms associated with DNA damage have been well-documented in the literature and may occur spontaneously during replication processes or from exposure to various environmental factors including chemicals, radiation, radon and UV light. DNA repair mechanisms maintain the integrity of DNA and mitigate nucleotide errors through a variety of processes, including mismatch repair (MMR), base excision repair (BER), and nucleotide excision repair(NER $)^{16}$.

In humans, there are four clinically important DNA mismatch repair proteins (MMR), including MLH1, MSH2, MSH6, and PMS2. In normal repair processes, the MMR proteins form heterodimers (MLH1/PMS2, and MSH2/MSH6, respectively) and excise single nucleotide mismatches and insertion / deletion loops from the DNA strand ${ }^{16}{ }^{28}$. Epigenetic changes to the MMR genes, such as hypermethylation of the promoter on the MLH1 gene, result in the loss of expression and consequent dysfunction of the DNA MMR proteins ${ }^{14,15,28}$. Deficiencies or dysfunction of the MMR proteins correlate with microsatellite instability in the tumor ${ }^{34,35,36,37}$.

Short segments of repeating nucleotides or microsatellites are located throughout the genome. These repeats are prone to nucleotide mismatch errors arising from polymerase slippage during the replication process ${ }^{29}$. The MMR pathway plays a key role in recognizing and excising errors, as described above. If the MMR proteins are deficient or not functioning properly, alterations occurring during the replication process are not corrected, and result in the accumulation of mutations ${ }^{14,15,28}$. 
Microsatellite instability (MSI) or MMR dysfunction is noted in approximately $15 \%$ of CRC tumors, with MLH1 being the most frequently deficient MMR protein ${ }^{23}$. MSI has both prognostic and therapeutic implications. Primary tumors that have deficient MMR proteins tend to respond to fluoropyrimidine therapy (5-flurouracil) and

consequently, confer improved outcomes ${ }^{23,30}$. Patient's whose tumors are MSI may also benefit from immunotherapy ${ }^{27}$.

\subsection{Mutations in the MAPK Pathway and CRC}

The relationship between mutations in the MAPK pathway and the development and progression of cancer have been well documented, with the RAS and RAF oncogenes being the most frequently encountered somatic mutations resulting in cancer ${ }^{15}$. RAS and RAF gain-of-function mutations bypass prerequisite EGFR signaling and independently activate the MAPK pathway ${ }^{31}$. RAS and RAF mutations rarely occur concomitantly, suggesting that these tumorigenic pathways differ and offer no selective advantage for tumors to harbor both ${ }^{5}$.

\subsection{KRAS}

The KRAS oncogene is responsible for activating the MAPK and $\mathrm{PIK} / \mathrm{AKT} / \mathrm{mTOR}$ signaling pathways by transmitting signals received from receptor tyrosine kinase (RTK) to BRAF and PIK3CA, respectively ${ }^{9}, 32,23$. Point mutations in the KRAS gene activate signaling pathways, independent of growth factor / RTK binding. The KRAS gene is one of the most frequently mutated genes associated with cancer and has been reported in numerous malignancies, including colon cancer, 
cholangiocarcinoma, pancreatic and lung cancer ${ }^{33}, 34$. The diversity and frequency of KRAS mutations is a hallmark feature of CRC, with approximately $40 \%$ of $\mathrm{CRC}$ tumors harboring at least one KRAS mutation ${ }^{9,34,35}$. Anatomically, KRAS mutations are distributed throughout the colon, with females more likely to have a KRAS mutation in transverse and descending colon compared to males ${ }^{35}$. In CRC, KRAS mutation analysis is currently conducted to predict the efficacy of anti-EGFR therapy, however, research is revealing that it may have a prognostic value as well ${ }^{34,36},{ }^{37}$. KRAS mutations primarily cluster around mutational hotspots in codons 12 and 13 $3^{9,32,35}$. KRAS mutation G12V has been associated with more advanced malignancies and confers a poorer prognosis compared to other KRAS mutations ${ }^{9,38},{ }^{34}$. Similarly, in recurrent and metastatic colorectal cancer (mCRC), KRAS G13D is associated with poor patient outcomes ${ }^{32}$. KRAS mutations may also be found in codons 61 and 146, with the later noted almost exclusively in $\mathrm{CRC}^{34}$. The significance of mutations in codons 61 and 146 has not been fully elucidated, as the recommendation to include these mutations as part of extended mutation analyses in the clinical laboratory was recently made ${ }^{9,32},{ }^{39}$.

\subsection{NRAS}

Approximately $2-4 \%$ of CRC have NRAS mutations ${ }^{5,9}$. NRAS mutations cluster within codons 12,13 and 61 and may represent a distinct subtype of CRC, because they demonstrate different clinicopathological characteristics vs those associated with other RAS-family genes ${ }^{32}$. Clinically, NRAS mutations arise in mucinous adenocarcinomas in the distal colon and are demographically associated with older patients. NRAS are often associated with localized disease and confer a better prognosis compared to $\mathrm{KRAS}^{40}$. 


\subsection{BRAF}

BRAF mutations are associated with a variety of malignancies, including melanoma, papillary thyroid carcinoma, colorectal carcinoma, ovarian and lung cancers $^{41}$. They are identified in $10-15 \%$ of CRC tumors and are typically mutually exclusive of KRAS mutations ${ }^{9,30,32}$. The most common BRAF mutation, (V600E), is associated with colon cancer arising in the proximal colon. Phenotypically, BRAF V600E is frequently identified in older, female patients with poorly-differentiated mucinous adenocarcinomas that demonstrate MSI ${ }^{9,30,32,42,43}$. Patients with BRAF mutations typically have a poorer overall survival when compared to patients whose malignancies demonstrate wild-type BRAF ${ }^{20,23}$. Consequently, BRAF mutation analysis is useful for the prognostic stratification of patients with colorectal cancer and also serves as a biomarker to assist oncologists with predicting patient response to anti-EGFR therapies ${ }^{44}$.

\subsection{PIK3CA}

The PIK3CA gene is responsible for activating the PIK/AKT/mTOR pathway ${ }^{10,45}$. Amino acid substitutions in the $\mathrm{p} 110 \alpha$ protein have been associated with a variety of cancers, including glioblastoma, gastric, head and neck, endometrial, breast, ovary, lung and colorectal cancers ${ }^{45,46,47}$. Point mutations in the PIK3CA gene are present in approximatley $10-20 \%$ of CRCs and are most frequently clustered in exons 9 and $20^{35,47}$. PIK3CA mutations are typically identified in poorly differentiated adenocarcinomas and concurrent metastatic liver samples ${ }^{42}$ Additionally, PIK3CA mutations present concomitantly with KRAS mutations and have been associated with chemoresistance ${ }^{42,48}$. 
Patients with PIK3CA / KRAS co-mutations reportedly have poor outcomes, with shorter disease-free survival and high mortality rates ${ }^{41}$. Research suggests that PIK3CA mutations may also be a biomarker to predict response to radiation therapy ${ }^{45}$.

Additionally, retrospective studies have suggested that PIK3CA mutation analysis may serve as a predictive marker for patients who'd benefit from adjuvant aspirin therapy, however, further data is needed to make testing for this biomarker a recommendation $^{39,49}$.

\subsection{Primary Tumor Location and Prognosis}

Numerous bodies of work have demonstrated that tumors arising in the proximal or right colon (i.e. cecum, ascending colon, hepatic flexure) have differing embryologic origins, molecular genetic signatures and prognoses compared to those arising in the distal or left colon (i.e. splenic flexure, descending $\&$ sigmoid colon) ${ }^{39,40}$. The sidedness of primary tumors has also been shown to be prognostically valuable, however, it would be an over simplification to think of the two "sides" of the colon as completely separate entities, as the prevalence of mutations varies within the anatomic sites on the same side of the colon as well as from cecum to rectum ${ }^{42}$.

In general, colon cancer arising in the proximal colon is demographically associated with older, female patients and patients with familial cancers that make them genetically predisposed to $\mathrm{CRC}^{9,42,50}$. Histologically, right-sided colon cancers arise from the serrated tumor pathway and tend to be classified as intermediate- to high-grade mucinous, signet-ring or undifferentiated adenocarcinoma at the time of diagnosis ${ }^{43},{ }^{50}$. 
Additionally, they tend to have an advanced American Joint Committee on Cancer (AJCC) pathology stage and greater extent of invasion compared to CRC that arise elsewhere in the $\operatorname{colon}^{51}$. Consequently, right-sided cancers are associated with a poor prognosis and a higher prevalence of recurrence and metastasis. When metastasis occurs, right-sided CRC tend to metastasize to regional lymph nodes, the peritoneum and liver ${ }^{50}$.

From a mutation characterization perspective, colon cancer arising in the proximal colon tends to demonstrate hypermethylation (CIMP) with a high level of microsatellite instability (MSI-High) ${ }^{50,52,53}$. KRAS mutations are detected in greater than $50 \%$ of tumors arising in the cecum and ascending colon, but this frequency decreases distally across the colon, with the exception being the rectum ${ }^{9,42}$. BRAF V600E mutations are also associated with right-sided colon cancer and generally denote a poor prognosis ${ }^{52}$. Anti-EGFR therapy is not recommended for patients with tumors arising in the proximal colon, because of the high frequency of RAS-family mutations ${ }^{30}$. Instead, anti-VEGF monoclonal antibody therapy may be the adjuant therapy of choice for patients with proximal colon cancers, along with standard cytotoxic agents, such as Folfox (5FU, leucovorin, oxaliplatin) or folfiri (5FU, leucovorin, irinotecan) ${ }^{41,42}$.

Colon cancer arising in the distal colon has a favorable prognosis compared to those arising in the proximal colon. Macroscopically, left-sided colon cancers encircle the wall of the colon, and constrict and narrow the lumen as they grow ${ }^{52}$. Consequently, they tend to be less advanced at the time of diagnosis, largely due to the early onset of clinical symptoms (i.e. blood in stool, narrow stool, obstruction) and shorter interval between carcinogenesis and diagnosis ${ }^{53}$. When metastasis occurs, left-sided colon 
cancers tend to metastasize to the lungs or bone ${ }^{50}$. Demographically, left-sided colon cancers are more common in males ${ }^{42}$. Mutationally, distal tumors are associated with PIK3CA mutations in the descending and sigmoid colon and KRAS mutations in the rectum $^{23,42}$. Additionally, distal tumors demonstrate chromosomal instability ${ }^{54}$. Patient's with left-sided colon cancer benefit from anti-EGFR monoclonal antibody therapies (i.e. Erbitux) in addition to cytotoxic therapy, i.e. Folfox / Folfiri, provided their tumor has normal, wt-KRAS ${ }^{32,42,55 .}$

\subsection{Therapeutic Strategies for CRC}

Treatment strategies for CRC is based on the histologic grade and stage of tumors as well as the molecular mutations they harbor. Colorectal cancers are pathologically graded and staged based on standards developed by the World Health Organization (WHO) and the American Joint Committee on Cancer (AJCC) ${ }^{23,56}$. WHO grading categorizes colonic adenocarcinomas based on the morphology of malignant cells as well as their architecture or organization within the tissue. Grade I adenocarcinomas are denoted as "well-differentiated" if the malignant cells microscopically resemble normal colonic cells with uniform, basally located nuclei, and $>95 \%$ of the malignant cells forming glands ${ }^{57,58}$. Grade II, moderately differentiated adenocarcinoma is characterized by a loss of nuclear polarity among the malignant cells, and $50-95 \%$ of the malignant cells forming glands within the tissue ${ }^{57},{ }^{58}$. Grade III, poorly differentiated adenocarcinoma, is characterized by sheets of malignant cells that largely lack glandular $\operatorname{architecture}^{57},{ }^{58}$. 
AJCC staging assists clinicians with determining prognosis and treatment options. It standardizes the reporting of the pathological features of tumors, and includes details regarding the depth of tumor invasion within the tissue and the extent of nodal, vascular and distant metastases. AJCC staging uses TNM nomenclature, where T represents the depth the tumor has invaded into the wall of the colon, $\mathrm{N}$ denotes the number of lymph nodes containing metastatic tissue and $\mathrm{M}$ designates distant site metastasis ${ }^{56,63}$. Stage I (T1 or T2) denotes localized tumors that haven't invaded beyond the muscularis propria in the abdominal wall. Stage II (T3N0, T4N0) denotes tumors that have invaded through the muscularis propria and penetrated the visceral peritoneum but have not invaded the lymph nodes. Stage III tumors invade the lymphatics and represent regional disease. Stage IV malignancies are those with distant metastasis to one or more organs ${ }^{56,63}$.

The National Comprehensive Cancer Care Network provides clinicians with treatment guidelines based on the resectability of the malignancy and AJCC staging information. For patients with localized disease (stage I-II) surgical resection and observation is the standard treatment. Some stage II malignancies (T3, T4), however, may carry a higher-risk for microinvasion, especially if the cells in the tumor were poorly differentiated or if the tumor penetrated the vascular or lymphatic system. For this subset of patients, adjuvant fluoropyrimidine therapy might be administered following surgical resection. Stage III-IV malignancies are often treated with surgical resection and chemotherapy. The specific treatment employed by clinicians is based on the tumor profile and comorbidities of the individual patient ${ }^{23}$. 
Chemotherapeutic treatment options for patients with CRC typically include 5fluorouracil (5FU) or its oral prodrug, Capacitibine ${ }^{59}$. Leucovorin, a compound similar to folic acid, is often administered with 5FU to facilitate the binding of 5FU to malignant cells, thereby enhancing its effect ${ }^{60}$. $5 \mathrm{FU}$ may also be administered in combination with other cytotoxic drugs, such as oxaliplatin or irinotecan. Additionally, monoclonal antibody therapies that target vasoendothelial growth factor or epidermal growth factor receptor may be prescribed, depending on the mutational status of the patient's tumor ${ }^{31}$.

The mutational status of colorectal tumors assists with therapy selection and efficacy. Studies have shown that patients with deficient MMR tumors respond better to 5FU therapy compared to those with proficient DNA repair mechanisms ${ }^{61,62}$. Additionally, studies have shown that patients with MMR tumors respond to checkpoint

inhibitor therapy ${ }^{27,62}$. The RAS-family (NRAS and KRAS) mutational status assists with identifying patients who'd benefit from anti-EGFR therapy in combination with 5FU. Patients with RAS mutations are ineligible for anti-EGFR therapy ${ }^{9},{ }^{39}$.

\subsection{Colorectal Cancer Mutation Testing}

The key societies that provide procedural recommendations to clinical laboratories updated the $\mathrm{CRC}$ molecular testing guidelines to standardize mutational analyses and facilitate targeted therapy selection. Specifically, the guidelines recommended that extended NRAS and KRAS mutation analysis be performed to determine the clinical utility of anti-EGFR therapy. Patients with RAS mutations don't benefit from anti-EGFR therapy and consequently, are ineligible for regimens that would 
otherwise include it. Further, BRAF V600E mutation analysis and microsatellite instability testing is recommended for prognostic stratification purposes. The societies also considered including PIK3CA mutation panels to their testing guidelines to facilitate the identification of patients who might respond to aspirin therapy, but there was insufficient evidence to formally make this recommendation. The authors noted, however, that there is a the need for additional research ${ }^{39}$

\subsection{Specific Aims of Work}

As the literature review supports, although CRC has been extensively studied, the prognostic and therapeutic role that individual mutations and co-mutational pathways play in individual chemotherapeutic response has not been fully elucidated. In this population-based study, we analyzed the clinicopathological features of a retrospective colorectal cancer patient cohort over a seven-year span of time. In chapter two, our specific aims were to examine (1) the relationships between specific clinicopathological variables and (2) identify variables that might facilitate the management and prognostic stratification of CRC patients.

In chapter three, our specific aims were to examine (1) the frequency and diversity of specific mutations, 2) determine the relationships between the mutations and clinicopathological variables, and 3) elucidate the tumor microenvironment at various stages of disease to potentially facilitate the development of new companion diagnostics and more effective patient management strategies. 


\section{A Retrospective Population-based Study of Colorectal Cancer in the Upper Peninsula of Michigan}

Cancer is the second leading cause of death for Michigan residents, with cardiovascular disease being the first ${ }^{53}$. The incidence rate for colorectal cancer is approximately $4 \%$, with a reported 36.3 individuals per 100,000 diagnosed with colon or rectal cancer each year ${ }^{63}$. This year, approximately 5,000 Michigan residents are expected to be diagnosed with $\mathrm{CRC}$ and an estimated 1,650 are expected to pass away as a result ${ }^{63}$. Similarly, according to the Michigan Cancer Surveillance Program, in the Upper Peninsula of Michigan, an average of 36 residents per $/ 100,000$ were diagnosed with CRC between 2012-2016 (Figure A.1). Fifty-eight percent of the malignancies had regional or distant metastatic disease at the time of diagnosis and an average of 13.3 residents per 100,000 passed away as a result (Figure A.2) ${ }^{64}$.

Risk factors for CRC have been well-documented and include genetic, environmental and lifestyle-associated factors ${ }^{65},{ }^{66}$. Colon cancer typically affects people who are over the age of 50, but first-degree relatives with a history of CRC, or a personal history of colon polyps or ulcerative colitis increase risk and are important considerations when determining the appropriate age to initiate CRC screening ${ }^{67}$. Lifestyle choices that contribute to an increased risk of developing colon cancer, including being sedentary, overweight or obese, consuming a high fat, low fiber diet with a high red meat content, and high-risk behaviors, like heavy alcohol and tobacco use $\mathrm{e}^{7,68,}$ 3. 
Michigan is ranked in the top ten states with a high prevalence of obesity, with 1 in every 10 adults having a BMI of $>30$ (obese) and $35 \%$ of residents being overweight

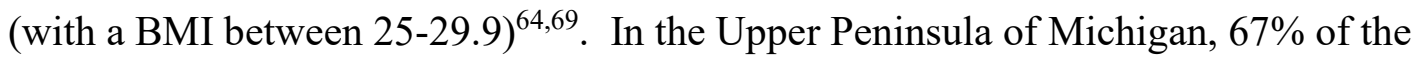
residents have a BMI that would rank them as either overweight or obese ${ }^{64,69}$. Additionally, Michigan residents report the following lifestyle choices that potentially increase risk of cancer: cigarette smoking (21\%), alcohol use (16\%), physically inactive lifestyle $(25 \%)^{64}$. Fortunately, seventy percent of respondents also reported that they follow the recommended CRC screening guidelines ${ }^{64}$.

The aim of this work was to examine (1) the relationships between specific clinicopathological variables in CRC patients and (2) identify variables that might facilitate the management and prognostic stratification of CRC patients.

\subsection{Materials and Methods}

\subsubsection{Study Design and Patient Population}

This retrospective, population-based study was based on a cohort of 541 patients who underwent surgical resection for primary, recurrent or metastatic colorectal cancer (CRC) between the years of 2004-2007 and 2013-2015 in a rural healthcare system in Michigan's Upper Peninsula. Patient consent forms were obtained according to institutional policies. Correlative, anonymized patient demographic and clinical pathological information was obtained from the Colon Cancer Tumor Registry following approval from the Institutional Review Board.

From this cohort, the age, gender, specific anatomic location of the primary malignancy, histological grade and AJCC stage of tumor, gastroenterologists procedural 
notes, surgical / chemotherapeutic / radiological treatment information and vital status was obtained.

\subsubsection{Inclusion and Exclusion Criteria}

This study included patients who underwent surgical resection for $\mathrm{CRC}$ and were $\geq 18$ years of age, with a diagnosis of primary, recurrent or metastatic adenocarcinoma of any histologic grade and AJCC stage (Tis-T4). Carcinomas, neuroendocrine carcinomas, carcinoid tumors and lymphomas that were surgically excised from the colon were also included in this retrospective study.

\subsubsection{Histological Classification of Colon Cancer}

Tumors belonging to this cohort of patients were categorized based on the World Health Organization's (WHO) histological grading and American Joint Committee on Cancer (AJCC), $7^{\text {th }}$ edition, staging as denoted in the cancer registry entries.

\subsection{Results}

\subsubsection{Patient Demographics}

Of the 541 cancer registry entries analyzed in this study, 56\% (303) belonged to male patients and $44 \%$ (238) belonged to females. The average age of the male subjects in this study was 66 years of age, with a range of 29 to 93 years of age. The average age of the female subjects in this study was 70 years of age, with a range of 19 to 96 years of age (see Table A.1).

\subsubsection{Distribution of Primary Tumors}

The primary malignancies in this study arose in the following anatomic locations: $14 \%$ cecum, $12 \%$ ascending colon, $2 \%$ hepatic flexure, $11 \%$ transverse colon, $2 \%$ splenic 
flexure, $2 \%$ descending colon, $18 \%$ sigmoid colon, and $22 \%$ rectum. Additionally, some of the samples in the cohort had the following "alternative" site designations: $5 \%$ right colon, $6 \%$ colon, $0.5 \%$ overlapping lesion, $1 \%$ left colon, $1 \%$ ileocecal valve, $1 \%$ appendix, and $0.2 \%$ anal-rectal junction (see Figure 2.3). In terms of proximal vs distal colon, the primary cancers had the following distribution pattern: $34 \%$ proximal colon (cecum, ascending colon, hepatic flexure), 11\% transverse colon, 24\% distal colon (splenic flexure, descending colon, sigmoid colon), $23 \%$ rectum, $1 \%$ appendix, $6 \%$ colon, NOS, $0.7 \%$ ileocecal valve, $0.3 \%$ overlapping lesion, NOS. The distribution of malignancies by anatomic site and patient demographics may be found in Figure A.4 and Table A.1.

\subsubsection{Histologic Grading and Staging by Tumor Site}

A majority of the tumors in our study were histological grade 2 adenocarcinomas, however, some of the tumors were only graded as "adenocarcinoma". Additionally, gastrointestinal carcinoid tumors, squamous cell carcinomas, lymphomas, and goblet cell tumors were included in this study.

The AJCC staging for the samples in this study were as follows: Stage $0(1 \%$; 4/541), Stage I (20\%, 109/541), Stage II (26\%; 144/541), Stage III (26\%; 142/541), Stage IV $(12 \% ; 62 / 541)$ and "unable to stage / stage x" (14\%; 77 / 541). AJCC staging wasn't applicable for three non-colonic malignancies (i.e. lymphoma, Burkitt's Lymphoma, and Squamous Cell Carcinoma). Approximately $30 \%$ of the malignancies arising in the ileocecal valve, cecum, ascending colon, and descending colon were AJCC Stage III malignancies while those arising in the hepatic flexure, transverse colon, and splenic flexure were primarily stage II malignancies; sigmoid colon and rectum were Stage I -II. 
In total, $48 \%$ of the patients in the cohort had localized disease (Stage I-II), with $26 \%$ having regional disease (Stage III) and 11\% having distant metastatic disease (see Figure A.4).

\subsubsection{Clinical Rationale for Colonoscopy Referral}

Based on data obtained from the gastroenterologist's procedural notes, forty-eight percent of the patients in this cohort had colonoscopies that were classified as "diagnostic" because they were experiencing classical clinical symptoms of colon cancer including blood in stool, rectal bleeding and/or positive fecal occult blood test results or had polyps \&/or suspicious lesions discovered during the colonoscopy procedure.

Unfortunately, the procedural notes indicated that the reason for the original referral was unknown in $20 \%$ of the patients in the cohort and $16 \%$ had colonoscopies performed without any additional ancillary text notes. Only $3 \%$ of the patients in the study had colonoscopies that were designated as "screening" and, interestingly, one patient had their cancer detected via virtual colonoscopy (see Table A.2).

\subsubsection{Treatment}

Treatment administered to this cohort consisted of the following: surgical intervention and observation (48\%), Surgical and chemotherapeutic treatment (33\%), surgical, chemotherapeutic and radiotherapy (18\%), surgical intervention and radiotherapy $(0.6 \%)$, patient declined chemotherapy $(0.6 \%)$.

\subsubsection{Vital Status}

Forty-three percent $(232 / 541)$ of the patients in our cohort had expired at the time the data was extracted from the system. From a demographic standpoint, 57\% (132/232) of the patients who expired were males and $43 \%$ (100/232) were females. The primary 
tumor location for patients who expired were as follows: $32 \%$ proximal colon $(75 / 232)$, $22 \%$ distal colon (51/232), 11\% transverse colon (26/232), $21 \%$ rectum $(49 / 232), 12 \%$ colon $(27 / 232)$ and $2 \%$ app (4/232). The vital status for this cohort is non-informative, as the cause of death was not specified in the registry data.

\subsection{Discussion}

To our knowledge, this is the first study to characterize the clinicopathological attributes of colon cancer in patients from the Upper Peninsula of Michigan. In our cohort, there was a slightly higher percentage of male patients (56\%) compared to female patients $(44 \%)$, but this is consistent with national demographic data and correlates with the fact that $22 \%$ of the malignancies in our cohort arose in the rectum ${ }^{3}$. The average age of male vs. female patients treated for CRC in Upper Michigan was 66 and 70 years of age, respectively, and is approximately 2 years younger than the national statistics ${ }^{3}$. Our cohort had a higher incidence of primary tumors arising in the proximal colon (34\%) compared to those arising in the distal colon (24\%). Interestingly, the incidence of proximal colon cancer was nearly $1.5 x$ higher than the national average of $20 \%$. This finding was not artificially increased by the number of females with malignancies in the right colon, because the male-to-female ratio was similar (i.e. $46 \%$ males vs $54 \%$ females).

Histologically, a majority of the colon cancers were histological grade 2. From an AJCC staging standpoint, the colon cancers in our cohort had a favorable staging distribution compared to national data, with nearly half of the patients (46\%) having tumors that were localized (grades $0-\mathrm{II})^{56}$. This may be evidence of the successful 
employment of early CRC screening programs and supports the Michigan Cancer Surveillance data in which $70 \%$ of Upper Michigan residents indicated they comply with CRC screening guidelines ${ }^{64}$. Additionally, only twenty-six percent of the patients in our study had regional disease and $12 \%$ had distant metastatic disease. Consistent with national trends, malignancies in the proximal colon (i.e. ileocecal valve, cecum, ascending colon) demonstrated more advanced disease, whereas those arising in the hepatic flexure and throughout the distal colon represented localized disease. The descending colon was the exception with $36 \%$ of the tumors being stage III. This largely supports the theory that, because of clinical symptoms, CRC in the distal colon is discovered and resected at earlier stages vs. those arising in the proximal colon.

We also noted that a majority of the gastroenterologists' procedural notes suggested that patients were referred for colonoscopies because of clinical symptoms associated with colorectal cancer. Additionally, we noted that $53 \%$ of patients had suspicious lesions or polyps identified during their colonoscopic procedure. The latter is counterintuitive to the CRC staging that we identified in our samples and is disconcerting as well. Access to routine healthcare and individual beliefs regarding preventative practices may present educational opportunities for the perusal of Upper Peninsula public health facilities.

\subsection{Conclusion}

This study provided a thorough clinicopathological picture of colorectal carcinoma in Michigan's Upper Peninsula. Knowing that patients in the UP have 1.5x the incidence of CRC arising in the proximal colon provides primary care physicians with 
the opportunity to encourage regular screening colonoscopies vs. other screening modalities that may not interrogate the proximal colon. This study also emphasized that our population is high-risk for $\mathrm{CRC}$, both from a body mass index standpoint, selfreported alcohol and tobacco product use, as supported by the prevalence of diagnostic colonoscopies.

\subsection{Future Opportunities}

The discovery of the predilection of proximal colon cancer in patients of rural Upper Michigan presents several opportunities for future initiatives. Firstly, it is clinically relevant knowledge that may benefit public health clinicians and primary care physicians by affording them the opportunity to development strategies to aid in the early detection of proximal CRC malignancies. Secondly, the knowledge gained from this study may benefit gastroenterologists and surgeons by alerting them to the need to interrogate the proximal colon when applicable. Thirdly, the findings of this work and the national increased incidence of CRC arising in younger adults merit the continued surveillance of the clinicopathologic features of CRC in Michigan's Upper Peninsula. 


\section{Colorectal Cancer in the Upper Peninsula of Michigan: A Population-based Study characterizing molecular mutations and clinical attributes}

An enormous amount of money and time has been invested in researching colon

cancer, and yet the heterogeneity of the disease renders us unable to identify a biomarker to effectively diagnose and treat this insidious disease. Innumerable articles and clinical trials speak to the need for additional insight into tumor evolution and the prognostic role that the primary tumor's anatomic location plays in therapeutic response $\mathrm{e}^{36,42,70,71}$. In this chapter, our specific aims were to (1) examine the frequency and diversity of specific mutations in our cohort, 2) determine the relationships between the mutations and clinicopathological variables, and 3) elucidate the tumor microenvironment at various stages of disease to potentially facilitate the development of new companion diagnostics and more effective patient management strategies.

\subsection{Materials and Methods}

\subsubsection{Study Design and Patient Population}

A retrospective analysis was performed on 120 patients who underwent surgical resection for primary, recurrent or metastatic colorectal cancer between the years 20042007 within a health network in Michigan's rural Upper Peninsula. Patient consent forms were obtained according to institutional policies. Correlative, anonymized patient demographic and clinical- pathological information was obtained from the Colon Cancer Registry following approval from the Institutional Review Board. 
In total, approximately two-thousand, five hundred zinc-formalin-fixed, paraffinembedded tissue blocks belonging to the patient cohort were retrieved and 230 blocks were selected for subsequent analysis. These "matched" samples represented various stages of disease (AJCC stage Tis-T4) and included biopsies, colon polyps with highgrade dysplasia / adenocarcinoma in-situ, resections of primary tumors, and resections with corresponding metastatic tissue. Carcinomas, neuroendocrine carcinomas, carcinoid tumors and lymphomas excised from the colon were excluded from the analysis.

The zinc-formalin-fixed, paraffin-embedded tissue samples were analyzed to identify the presence of 73 possible point mutations in the KRAS, BRAF/NRAS, and PIK3CA genes. Additionally, immunohistochemical stains (i.e. MLH1/PMS2, MSH2/MSH6) were performed to characterize the functionality of the DNA mismatch repair system and PD-L1 expression (adaptive immunity) in the tumor cells.

\subsubsection{Tissue Selection and DNA extraction}

Hemotoxylin and Eosin-stained slides were retrieved and reviewed by the PI and a pathologist to confirm the diagnosis, histologic grade and staging of each sample.

Optimal blocks, defined as those with $\geq 10 \%$ tumor content, were selected for subsequent mutation and IHC analysis.

DNA was manually extracted from the archived tissue blocks using the Cobas ${ }^{\circledR}$ DNA Sample Preparation Kit (Roche, Indianapolis, IN). Specifically, a five- $\mu$ m section was obtained from each tissue block and placed in a 1.5ml PCR-safe tube, using protocols previously described to avoid DNA contamination ${ }^{72}$. Next, the section was deparaffinized in xylene and rehydrated in $100 \% \mathrm{ETOH}$. The tissue was lysed via a 
protease and passed through a filter column to sequester the DNA and remove impurities. The nucleic acids were eluted from the filter and the genomic DNA concentration was determined via a Nanodrop spectrophotometer. The concentration of the stock DNA in each sample was diluted to $2 \mathrm{ng} / \mathrm{ul}$, using a dilution calculation provided by the manufacturer, to standardize DNA content in the samples prior to the amplification and mutation detection. Stock samples were stored in the $-20^{\circ} \mathrm{C}$ freezer until use.

Also per the manufacturer's specifications, samples initially yielding invalid mutation test results were retested after new dilutions of the stock DNA were prepared. If invalid results were acquired a second time, fresh DNA was extracted from a new $5 \mu \mathrm{m}$ section of FFPET tissue.

\subsubsection{K-RAS Kirsten Rat Sarcoma Viral Oncogene Homolog (KRAS) Mutation} Analysis

"Extended" KRAS mutation analysis was performed using a "life science, research only" (Roche Diagnostics, Indianapolis, IN). The assay utilized real-time PCR, specific base-pair primers and fluorescence resonance energy transfer (FRET) probes to detect mutations in the following targeted KRAS regions: KRAS Exon 2, codons 12 and 13 (G12A, G12C, G12D, G12R, G12S, G12V, G13A, G13C, G13D, G13R, G13S, G13V), KRAS Exon 3, codons 59 and 61 (A59E, A59G, A59S, A59T, Q61E, Q61Hc, Q61Ht, Q61K, Q61L, Q61P, Q61R), KRAS Exon 4, codons 117 and 146 (K117Nc, K117Nt, A146P, A146T, A146V). A mutant control, a process control and a negative control were incorporated into each run to confirm the validity of the run. Following the completion of the RT-PCR reaction, all data files were uploaded into the Roche web tool (http://oncologyresearchkits.roche.com/data-analysis) for analysis. 


\subsubsection{B-RAF Proto-oncogene (BRAF) and Neuroblastoma RAS Viral Oncogene Homolog (NRAS) Mutation Analysis}

"Extended" BRAF and NRAS mutation analysis was performed using a "life science, research only" assay developed by Roche Diagnostics (P/N: 07659962001, Roche Diagnostics, Indianapolis, IN). The assay utilized real-time PCR, specific basepair primers and fluorescence resonance energy transfer (FRET) probes to detect the following mutations: BRAF Exon 11 (G466A, G466V, G469A, G469R, G469V), BRAF Exon 15 (V600E, V600E2, V600D, V600K, V600R, K601E), NRAS Exon 2 (G12A, G12C, G12D, G12R, G12S, G12V, G13A, G13C, G13D, G13R, G13S, G13V, A18T), NRAS Exon 3 (Q61Ht, Q61Hc, Q61K, Q61L, Q61P, Q61R), and “other” NRAS Exon 3and 4mutations, including A59D, K117Nc, K117Nt, A146T, A146V. A mutant control, a process control and a negative control were incorporated into each run to confirm the validity of the run. Following the completion of the RT-PCR reaction, all data files were uploaded into the Roche web tool (http://oncologyresearchkits.roche.com/data-analysis) for analysis.

\subsubsection{Phosphatidylinositol-4,5-Bisphosphate 3-Kinase, Catalytic Subunit Alpha (PIK3CA) Mutation Analysis}

"Extended" PIK3CA mutation analysis was performed using a "life science, research only" assay (Roche Diagnostics, Indianapolis, IN). The assay utilized real-time PCR, specific base-pair primers and fluorescence resonance energy transfer (FRET) probes to detect the following mutations or targeted regions: PIK3CA Exon 1 (R88Q), PIK3CA Exon 4 (N345K), PIK3CA Exon 7 (C420R), PIK3CA Exon 9 (E542K, E545A, E545D, E545G, E545K, Q546E, Q546K, Q546L, Q546R), PIK3CA Exon 20 H1047L, 
H1047R, H1047Y, G1049R). Following the completion of the RT-PCR reaction, the mutation analysis was performed by the Cobas $480 \mathrm{z}$ analyzer. A mutant control, a process control and a negative control were incorporated into each run to confirm the validity of the run.

\subsubsection{Immunohistochemical Assessment of DNA Mismatch Repair Proteins}

A series of immunohistochemical stains were performed using the Benchmark Ultra System (Roche Ventana, Tucson, Arizona) to assess the presence or absence of nuclear expression in neoplastic cells for four DNA mismatch repair proteins, MLH1/PMS2 and MSH2/MSH6. Four serial tissue sections ( $4 \mu \mathrm{m})$ were collected from each FFPET block and mounted on positively-charged microscope slides. The first slide was stained with anti-MLH1 (clone M1) (Roche Ventana, Tucson, Arizona); the second slide was stained with anti-MSH2(clone G219-1129) (Roche / Ventana, Tucson, Arizona); the third slide was stained with anti-MSH6 (clone 44) (Roche / Ventana) and the fourth slide was stained with anti-PMS2(clone EPR3947) (Roche / Ventana, Tucson, Arizona). "Pre-qualified" colon cancer tissue (i.e. colon cancer tissue that previously demonstrated intact MMR proteins) served as the positive control tissue. All slides were independently reviewed and scored by both the PI and a qualified pathologist to determine the mismatch repair protein status.

\subsubsection{Immunohistochemical Assessment of PD-L1 Expression} Immunohistochemical assays were performed on the Benchmark Ultra (Roche/Ventana, Tucson, AZ) using anti-PDL-1 antibody (clone SP263) 
(Roche/Ventana, Tucson, AZ) to evaluate PDL-1 membranous expression in tumor cells in cohort tissue samples. Specifically, three $(4 \mu \mathrm{m})$ serial sections of tissue were mounted on positively charged glass slides. Hematoxylin \& Eosin staining was performed on the first slide to confirm specimen adequacy (i.e. each section contained $>50$ viable tumor cells with associated stroma, per manufacturer guidelines). If deemed adequate, the second slide containing patient tissue was stained with PDL-1 (clone SP263) and the third with a Rabbit Monoclonal Negative Reagent Control. Human term placental tissue was used for the positive control tissue.

PDL-1 (SP263) was independently quantified by the PI and a qualified pathologist, using investigator-developed scoring criteria to facilitate reproducibility. Specifically, PDL-1 stained malignant tissue was methodically evaluated and the aggregation method was utilized to score percent positivity of membranous staining in viable tumor cells, as follows: $0-<1 \%, 1-9 \%, 10-29 \%, 30-49 \%, 50-69 \%, 70-89 \%, 90-$ $100 \%$. Staining of tumor infiltrating immune cells (IC) served as an internal control and was qualitatively noted but not quantified.

\subsection{Statistical Analysis}

While much of the analyses in this study were performed using descriptive statistics, $R$ 3.5.3 software (https://www.r-project.org/) was utilized to assess the association between mutational status and various clinical-pathological parameters. 


\subsection{Results}

\subsubsection{Patient Demographics}

Of the 120 cancer registry entries analyzed in this study, $58 \%$ belonged to male patients and $42 \%$ belonged to females. The average age of the male subjects in this cohort was 66 years of age, with a range of 33-89 years of age. The average age of the female subjects in this study was 73 years of age, with a range of 45 - 90 years of age.

\subsubsection{Distribution of Primary Tumors by Anatomic Site}

The primary malignancies in this study were distributed across the anatomic sites of the colon, as follows: $13 \%$ cecum, $14 \%$ ascending colon, $5 \%$ hepatic flexure, $12 \%$ transverse colon, $4 \%$ splenic flexure, $2 \%$ descending colon, $19 \%$ sigmoid colon, $18 \%$ rectum (Figure A.5). Additionally, some of the samples in the cohort had "alternative" site designations, including: $6 \%$ right colon, $4 \%$ colon, $2 \%$ ileocecal valve, $1 \%$ overlapping lesion, $2 \%$ left colon. From a proximal vs distal standpoint, the distribution of primary malignancies was as follows: $42 \%(51 / 120)$ proximal colon, $12 \%(14 / 120)$ transverse colon, $23 \%(27 / 120)$ distal colon, $18 \%$ rectum, $1 \%$ (1/120) appendix, and 4\% (5/120) colon, NOS (Figure A.6).

\subsubsection{Histologic Grading and Staging by Anatomic Site}

The histological grade for the samples in our cohort were as follows: grade 0 (2\%), grade $1(2 \%)$, grade $2(73 \%)$, grade $3(19 \%)$ and grade $4(4 \%)$. The AJCC staging for the samples in this study were as follows: Stage I (29\%), Stage II (35\%), Stage III (30\%), Stage IV (6\%) and "unable to stage / stage x" (0.8\%). A majority of the 
malignancies arising in the ileocecal valve, cecum, sigmoid and rectum were AJCC Stage III malignancies while those arising in the ascending and transverse colon flexure, splenic and hepatic flexures were Stage II.

\subsubsection{KRAS Mutation Status by Tumor Location}

KRAS mutations were identified in $36 \%$ of the patients in our study, with $84 \%$ of the mutations arising in exon 2. Thirty-five percent of the samples with a KRAS mutation arose in the proximal colon $(\mathrm{p}=0.04)$. Thirty-four percent of the malignancies with a KRAS mutation were AJCC stage I, and the mutations showed a similar distribution pattern across histological grades I-III. Interestingly, 23\% of the patients with a KRAS mutation had co-occurring mutations, with $80 \%$ of these being PIK3CA point mutations.

Point mutation G12x accounted for $63 \%$ of the KRAS mutations identified in our cohort (Table A.4). Malignancies with this mutation were anatomically distributed across the colon, and were primarily histologic grade 2, AJCC stage I-II tumors. Interestingly, $26 \%$ of the patients with the G12x mutation had metastatic disease, $7 \%$ had synchronous malignancies and 4\% experienced recurrence. Additionally, 22\% of the patients with KRAS G12x mutation had concomitant mutations, with $27 \%$ of these being PIK3CA co-mutations (E545x, H1047x, Q546x). One patient had a BRAFV600E / KRAS G12x co-mutation, which reportedly occurs in $0.001 \%$ of CRC tumors ${ }^{47}, 15$.

Twenty-one percent of the patients with a KRAS mutation had a G13x point mutation in Exon 2 (Table A.5). Thirty-three percent of these had metastatic colon 
cancer, and another patient with this mutation experienced recurrence in a different location in her colon two years after the diagnosis and treatment of her original malignancy. The tumor cells in this patient's original resection demonstrated PD-L1 expression and, while PD-L1 expression was not noted in subsequent specimens, the KRAS G13x mutation was. All of the samples with the KRAS G13x mutation were histological grade 2, with 54\% being AJCC Stage III. Of these samples, $64 \%$ arose in distal colon.

Mutations in exons 4 and 3 comprised $9 \%$ and $5 \%$ of the KRAS mutations in our cohort, respectively. The KRAS A146x mutation was detected in two patients, and each had concomitant PIK3CA mutations as well. Two patients also had the KRAS K117x mutation identified in their samples. Both of these patients had metastatic CRC, with malignancies arising in the distal colon. The KRAS Q61x was identified in one patient in our cohort. This patient also had a co-occurring PIK3CA mutation, C420R. Finally, one patient had the A59x mutation detected in a grade 3 adenocarcinoma collected from the sigmoid colon (Table A.5).

\subsubsection{BRAF Mutation Status by Anatomic Site}

The BRAF V600E mutation was identified in approximately $18 \%$ of the patients in our cohort. BRAF V600E mutation was associated with females ( $p=.001)$, with seventy-six percent of the patients with a BRAF mutation being female and twenty-four percent male. Fifty-four percent of the malignancies with the BRAF V600E mutation arose in the proximal colon (cecum, ascending, and "right colon, NOS). Eighteen percent of the BRAF V600E point mutations arose in the transverse colon, with nine percent 
arising in the splenic flexure and sigmoid colon, respectively. From a grading and staging standpoint, a majority of the tumors with BRAF mutations were histologic grade II or III and represented localized disease (Table A.6).

\subsubsection{NRAS Mutation Status by Anatomic Site}

Only $6 \%$ of the patients in our study had NRAS mutations detected in their tumor samples, with two patients having metastatic $\mathrm{CRC}$ and one chemoresistant cancer. The average age of patients with this mutation was 67 years old, with a range of 51-84 years. Seventy-one percent of the NRAS mutations were in exon 3 (Q61x). Forty-three percent of the NRAS mutations arose in the proximal colon, and overall, the specimens with NRAS mutations were histological grade II, AJCC stage I (Table A.7). No concomitant mutations were identified in the patients with NRAS mutations.

\subsubsection{PIK3CA Mutation Status by Anatomic Site}

Sixteen percent of the patients in our study had a PIK3CA mutation detected in their tumor, with a majority of these arising in exons 9 and 20. Patients with a PIK3CA mutation were, on average, 68 years of age. Twenty one percent of the patients with a PIK3CA mutation had metastatic disease and sixteen percent had synchronous malignancies. Overall, fifty-three percent of the samples with a PIK3CA mutation had one additional co-occurring mutation, and 10\% had two concomitant mutations (Table A.8). Interestingly, two patients in our study had co-occurring PIK3CA mutations with an additional BRAF V600E or KRAS G12x mutation. One of the individuals was initially treated for a synchronous malignancy and two years later, experienced recurrent 
CRC. More than half of the malignancies harboring PIK3CA mutations arose in the proximal colon and were categorized as histological grade 2, AJCC Stage II lesions.

\subsubsection{Concomitant Mutations by Anatomic Site}

Twenty-nine percent of the patients in our cohort had multiple mutations identified by IHC or PCR-based mutation analyses (Table A.9). Of these, $43 \%$ had primary tumors arising in the proximal colon, with ascending colon having the greatest number of co-mutations. Additionally, the frequency of concomitant mutations gradually decreased from the transverse colon (11\%) to the rectum $(3 \%)$.

\subsubsection{Immunohistochemical Analysis of DNA Mismatch Repair Proteins}

Eighty percent of the patients in our study had malignancies with intact MMR proteins, while $17 \%$ demonstrated a loss of two repair proteins and 3\% showed the loss of expression of one DNA repair protein (Figures A.7-A.10 and Tables A.10-A.12). Of the patients with intact MMR proteins, $31 \%$ had metastatic disease. Sixty-one percent of the tumors with intact MMR proteins belonged to males with primary malignancies predominantly arising in the sigmoid colon and rectum. Conversely, a majority of the samples demonstrating the loss of two MMR proteins primarily belonged to female patients (58\%) with malignancies arising in the proximal colon. As may be expected, BRAF V600E mutation was often associated with deficient MMR protein expression $\left(\mathrm{p}=2.2^{\wedge} 10^{-5}\right)$ 


\subsubsection{Immunohistochemical Analysis of PD-L1 Expression}

Ten percent of the patients in our cohort had measurable PD-L1 expression levels in their tumor cells, however, expression varied among the matched patient samples (Figures A.11-A.12). In general, PD-L1 expression was observed more frequently in tumors arising in the sigmoid and "right colon", followed closely by those in the rectum, ascending colon and cecum. PD-L1 expression levels of $>30 \%$ were observed in only $6 \%$ of our cohort, and was noted in patients with metastatic disease whose tumors arose in the cecum. Tumors exhibiting 10-29\% PD-L1 expression was noted in a patient whose malignancy arose in the appendix and in another patient who had a synchronous malignancy and later experienced recurrent adenocarcinoma in the proximal colon (Table A.13).

\subsubsection{Characterization of Synchronous Malignancies}

Six patients ( 3 males, 3 females) in the cohort had synchronous malignancies (Table A.14). The average age of the patients with synchronous malignancies was 78 years of age for the males and 74 for the females. The anatomic distribution of the malignancies was as follows: $8 \%$ ileocecal, $17 \%$ cecum, $25 \%$ ascending colon, $8 \%$ transverse, $17 \%$ descending colon and $25 \%$ sigmoid colon. Sixty-seven percent of the synchronous malignancies were histological grade II and 50\% were classified as AJCC stage I tumors.

Interestingly, sixty-seven percent of the synchronous malignancies had intact MMR proteins and 50\% had identical mutations within the paired samples. No mutations were identified in four of the synchronous malignancies arising in the ileocecal valve, 
sigmoid colon, and cecum. Paired synchronous malignancies arising in the ascending and transverse colon demonstrated a loss of the MLH1/PMS2 MMR proteins and the BRAF V600E mutation.

Paired malignancies with divergent mutations included two samples from the descending colon, where one sample demonstrated $<1 \%$ PD-L1 expression and a KRAS G12x mutation, while the other only demonstrated a PIK3CA E545x mutation.

Additionally, one synchronous malignancy originating in the sigmoid colon showed a KRAS G12x mutation while the other tumor did not. Finally, one synchronous malignancy originating in the ascending colon demonstrated a loss of both MLH1/PMS2 MMR proteins, while the other only displayed a loss of MLH1. The PIK3CA E454x mutation was identified in both of these paired malignancies.

\subsubsection{Characterization of Recurring Malignancies}

Three female patients in our study experienced recurrent colon cancer within two years post-surgical excision of their primary malignancy. Another patient initially had synchronous malignancies and later developed recurrent cancer. Fifty percent of these tumors arose in the rectum, with the remaining malignancies arising in the "right colon, NOS" (38\%) and sigmoid colon (12\%). Fifty percent of the tumors were histologically a grade 2, with a majority being AJCC stage II (Table A.15).

Interestingly, the mutations in the recurrent malignancies largely resembled those in the original primary cancer. For instance, for one patient, the KRAS G12x mutation was identified in both the primary and recurring malignancy arising in the rectum. 
Another patient had synchronous tumors arising in the "right colon" that exhibited a loss of both MLH/PMS2 MMR proteins, the BRAF V600E mutation and PIK3CA mutations H1047x and E545x. Additionally, both demonstrated PD-L1 expression in the tumor cells, with $10-29 \%$ expression in one and $1-9 \%$ expression in the other. Two years later, the recurrent cancer in the biopsy and resection demonstrated a similar loss of MMR proteins, PD-L1 expression levels and BRAF V600E mutation. The PIK3CA mutations, however, were not detected in the recurrent malignancy. Lastly, a malignancy that arose in the sigmoid colon displayed 1-9\% expression of PD-L1 and the KRAS G13x mutation. The recurrent cancers in the rectum did not express PD-L1 but the KRAS G13x mutation was identified in each.

\subsubsection{Characterization of Chemoresistant Malignancies}

Approximately $7 \%(8 / 120)$ patients in this study had malignancies that were presumed to be chemoresistent, based on multiple courses of cytotoxic therapy administered over an extended amount of time and treatment notes (Table A.16). Chemoresistence was noted evenly between males and females in this category (4/8 or $50 \%$ each). The average age for the males in this category was 51 years of age (range from $46-53$ years of age) and 62 for females, with a range of 45-70 years of age. The anatomic location of primary malignancies was as follows: $25 \%(2 / 8)$ rectum, $12.5 \%$ (1/8) for each of the following sources: Overlapping lesion, Ascending, Transverse, Sigmoid, Colon, and Right colon. Mutations characterized in this subset of patients / samples included the following: KRAS G13x was detected in one patient's sample (sigmoid), KRAS G12x was detected in one patient's sample (transverse), KRAS 146x 
and PIK3CA E545x was detected in one patient sample (ascending colon), NRAS Q61x and MMR repair protein markers (loss of PMS2) was detected in one patient sample (right colon). Interestingly, we were unable to identify mutations in no mutations in samples belonging to $50 \%$ of the patients.

In terms of histologic grade and AJCC staging of chemoresistent tumors, $75 \%$ $(6 / 8)$ of the patients had malignancies that were histological grade 2 and $25 \%(2 / 8)$ of the patients had malignancies that were histological grade 3 . Fifty percent (4/8) of the patients had malignancies that were Stage III (3@T3N1M0, $1 @$ T2N2M0),38\%(3/8) had malignancies that were Stage II (3@ T3N0M0) and 12\% (1/8) had a malignancy that was Stage IV (T3N2M1).

\subsubsection{Characterization of Malignancies That Mutations Weren't Detected In}

Twenty-two percent of the patients in our cohort had malignancies that we were unable to identify mutations in (Table A.17). Of these, $26 \%$ were from patients with metastatic CRC. Seventy-eight of these samples belonged to male patients, with an average age of 68 years of age. These tumors were distributed across the following anatomic sites: $44 \%$ rectum, 18\% sigmoid, 11\% hepatic flexure, $7 \%$ transverse, $4 \%$ ascending, 7\% cecum, 4\% overlapping lesion, 4\% right colon. Eighty-one percent of these malignancies were histological grade 2, with a majority being AJCC stage I or II.

\subsubsection{Characterization of Patients with Cancer-related Cause of Death}

Thirty-seven percent (44/120) of the patients in our cohort passed away from cancer-related causes, with 48\% (21/44) male and 52\% (23/44) female. Thirty-four 
percent of these patients (15/44) were initially diagnosed with mCRC, whereas $57 \%$ $(25 / 44)$ originally were diagnosed with localized cancer or had synchronous \&/or recurrent cancer $(9 \%, 4 / 44)$. Anatomically, the tumors distributed as follows: cecum $16 \%(7 / 44)$, ascending $9 \%(4 / 44)$, hepatic flexure $7 \%(3 / 44)$, transverse $14 \%(6 / 44)$, splenic flexure 5\% (2/44), descending 7\% (3/44), sigmoid 11\% (5/44), rectum $18 \%$ (8/44), overlapping lesion $2 \%(1 / 44)$, ileocecal valve $2 \%(1 / 44)$, right colon $7 \%(3 / 44)$, and colon $2 \%(1 / 44)$. In terms of sidedness of the colon, $43 \%(19 / 44)$ of the tumors in this category arose in the proximal colon, $23 \%(10 / 44)$ arose in the distal colon, $14 \%$ $(6 / 44)$ were located in the transverse colon and $18 \%(8 / 44)$ were in the rectum (Table A.18).

Of the patients who originally had metastatic disease and passed away due to cancer-related causes, $53 \%$ were female $(8 / 15)$ and $46 \%$ were male $(7 / 15)$, with an average age of 71 years and 67 years at the time of diagnosis, respectively. Interestingly, although these patients had mCRC, 33\% had tumors that only demonstrated regional disease, with AJCC staging T3N1M0 (stage III). The tumors in this subgroup were comprised of the following mutations: BRAF V600E (20\%), KRAS G12x (27\%), PDL-1 expression (7\%), PIK3CA G1049R (7\%), PIK3CA N345K (7\%), NRAS Q61x (7\%), KRAS A146x (7\%), KRAS K117x (7\%). Interestingly, 27\% (4/15) of the tumors in this subset had no mutations identified.

Of the patients who originally had localized disease, 55\% were female $(6 / 11)$ and $45 \%$ were male $(5 / 11)$, with an average age of 75 years and 65 years at the time of diagnosis, respectively. Twenty-seven percent (3/11) of the patients in this subset went on 
to develop secondary malignancies in the lung, pelvis or small intestine. The primary tumors primarily arose in the transverse, ascending colon and hepatic flexure, but tumors were also noted in the cecum, sigmoid. Forty-four percent of the tumors were AJCC stage II (T3N0M0). The tumors from this subgroup were comprised of the following mutations: 45\% BRAF V600E, 27\% MMR showing loss of MLH1/PMS2, 27\% PDL-1 expression in the tumor cells, 18\% PIK3CA E545x, and 9\% had a PIK3CA H1047x or KRAS G12x mutation. Interestingly, 27\% (3/11) of the tumors in this subset had no mutations identified.

The sample size (5/44) was very small for the patients who originally had refractory CRC or synchronous malignancies and died from cancer-related causes. The 13 samples for this subset were predominately grade 2 lesions with AJCC staging ranging from stage I -III. Interestingly, many of the recurrent malignancies demonstrated a similar mutation pattern compared to the original cancer.

\subsection{Discussion:}

Although numerous studies have focused on colorectal cancer, to our knowledge, this is the first study to characterize the molecular mutations and clinicopathological attributes of colon cancer in patients from the Upper Peninsula of Michigan. Based on our data, the Upper Peninsula has a higher incidence of primary CRC arising in the proximal colon compared to percentages published in the literature ${ }^{73}$. This finding doesn't appear to be biased by the composition of our cohort, as there was a higher percentage of male patients (58\%) vs female patients (42\%) in our study. 
The prevalence of KRAS, NRAS, BRAF, and PIK3CA mutations in our cohort concurred with the frequencies published in the literature, as did the MMR / MSI status. Although not statistically significant, we observed KRAS G12x and G13x mutations in mCRC in our study, which anecdotally correlates with the poor outcomes described by other bodies of work ${ }^{39,34,35}$. Additionally, PIK3CA mutations, most notably the H1047x and E545x, were associated with a poor prognosis. Forty-two percent $(8 / 19)$ of the patients with a PIK3CA mutation died from cancer-related causes and most had tumors arising in the transverse, descending and sigmoid colon. We also noted that more than half of the tumors with a PIK3CA mutation had a concomitant mutation. These observations are consistent with those described in the literature ${ }^{74},{ }^{75},{ }^{36}$.

We observed a relationship between BRAF and MMR / MSI, with a higher incidence of MMR in female patients ( $\mathrm{p}=0.02$ and $\mathrm{p}=0.001$, respectively) with malignancies arising in the ascending colon, as also described in the literature ${ }^{76}$. Additionally, as Rosenbaum, et al also noted, we observed a relationship between tumors exhibiting PD-L1 expression and BRAF V600E mutation ${ }^{24}$. Further, our study demonstrated a concomitant KRAS and BRAF mutation which conflicts with the theory that these two mutations occur mutually exclusive of each other ${ }^{71}$. This phenomenon, albeit extremely rare, had been observed by other researchers ${ }^{77},{ }^{78}$.

Although only $6 \%$ of the patients in our cohort had an NRAS mutation, the NRAS Q61x was the most frequently identified NRAS mutation and was associated with tumors arising throughout the colon. Seventy-one percent of all of the NRAS mutations in this 
cohort were associated with localized disease (Stage I-II), as noted in previous works by Takane, et al and Ahmed, et al $1^{5,35}$.

We had the opportunity to characterize synchronous malignancies belonging to 6 individuals in our cohort. Interesting, the male-to-female ratio was even and there was a predilection for synchronous tumors to arise in the proximal colon (i.e. ileocecal, cecum and ascending). While the remaining tumors arose in the distal (descending and sigmoid) and transverse colon, $42 \%$ and $8 \%$, respectively, none were associated with the rectum. We observed that a majority of these tumors had intact MMR proteins and the paired synchronous samples that had identical mutations arose in the ascending and transverse colon whereas those with divert mutations arose in the descending and sigmoid colon. Although synchronous cancers may be found throughout the colon, our findings correlate with work performed by Lam et al, from the observation that synchronous cancers were primarily noted in the proximal colon ${ }^{75}$. We differed in our gender observations and the predilection for MMR, but this discrepancy is likely due to our small sample size.

We also had a subset of patients that experienced refractory malignancies. This portion of the cohort was too small to make anatomic site comparisons, but we did notice mutation patterns in the matched samples. Specifically, we noticed that the synchronous malignancies had identical or similar mutation patterns in the matched samples. This observation was also noted in patients who experienced recurrent $\mathrm{CRC}$ after having synchronous malignancies. We also noticed that several of the samples had deficient MMR, but this isn't generalizable due to our small sample size. 
From a clinicopathological perspective, the chemoresistent patients (7\%) in our cohort were as challenging to characterize as they likely were to treat. We observed a RAS family mutation in half of these patients, with no mutations identified in the remaining 50\%. Seventy-five percent had tumors that were histological grade 2 and $50 \%$ had regional lymphatic invasion. Half of this sample set received surgical, chemotherapeutic and radiotherapy and the other 50\% received surgical, chemotherapeutic therapies followed by observation. Similarly, we observed a subset of malignancies that we were unable to identify mutations in. Interestingly, a majority of these tumors belonged to males, with $44 \%$ of these tumors originating in the rectum. A majority of these tumors were grade 2 and represented localized disease. Together, we believe these findings correlate with the heterogeneity of CRC and the treatment challenges it $\operatorname{poses}^{23},{ }^{79}$.

\subsection{Limitations of the Study}

Although there were many strengths of this study, there were also numerous limitations as well. We had a relatively small sample size and didn't have access to a detailed clinical history for the patients in our cohort. Therefore, we don't know if the patients in our study had a history of diabetes, inflammatory bowel disease or previous cancer. We also don't know our cohort's genetic background, ethnicity, dietary habits, and exposure to tobacco, alcohol, or survival details from diagnosis to death. We didn't have access to information regarding the ischemia time post specimen collection or about the storage conditions of our tissue blocks. Because we wanted to correlate the frequency 
and diversity of mutations with clinicopathological data, there also may be some selection bias associated with our study.

\subsection{Conclusion}

In this novel population-based study, we comprehensively analyzed mutations in the MAPK, PIK3CA, and DNA mismatch repair pathways and correlated our findings with the clinicopathological attributes belonging to the patients in our cohort. From a primary tumor location perspective, we noted that there is a predilection for primary CRC to arise in the proximal colon of patients in the Upper Peninsula of Michigan. From a mutation status and patient outcomes perspective, although anecdotal due to the small size of our cohort, we observed PIK3CA (H1047x, E545x) and KRAS (G12x, G13x) mutations to be associated with a poor prognosis, including cancer-related death.

We also had the opportunity to analyze mutations at various stages of disease in matched samples, including biopsies, resections, metastatic disease and synchronous and recurrent malignancies. We largely observed an analogous mutational status among matched patient samples which may be clinically informative regarding treatment strategies for refractory malignancies. In total, we believe our work will inspire future patient and clinician educational initiatives and research endeavors. Additionally, this work may facilitate the development of future companion diagnostic tests and improved patient management strategies. 


\subsection{Future Opportunities}

This study may provide the catalyst for several future studies. The increased number of $\mathrm{CRC}$ arising in younger patients, the predominance of primary tumors arising in the proximal colon and the observation that specific KRAS and PIK3CA mutations may be associated with an inferior patient prognosis provide justification and will hopefully spark additional prospective research endeavors. Additionally, the subset of malignancies with mutations that precluded detection in our study present a unique challenge and research opportunity for future work. 


\section{Reference List}

1. Key Statistics for Colorectal Cancer. https://www.cancer.org/cancer/colon-rectalcancer/about/key-statistics.html.

2. Cancer of the Colon and Rectum - Cancer Stat Facts. SEER https://seer.cancer.gov/statfacts/html/colorect.html.

3. Street, W. Colorectal Cancer Facts \& Figures 2017-2019. 40.

4. The Cancer Genome Atlas Network. Comprehensive molecular characterization of human colon and rectal cancer. Nature 487, 330-337 (2012).

5. Takane, K. et al. DNA methylation epigenotype and clinical features of NRASmutation(+) colorectal cancer. Cancer Med 6, 1023-1035 (2017).

6. Komiya, Y. \& Habas, R. Wnt signal transduction pathways. Organogenesis 4, 68-75 (2008).

7. Zhan, T., Rindtorff, N. \& Boutros, M. Wnt signaling in cancer. Oncogene 36, 14611473 (2017).

8. Farooqi, A. A., de la Roche, M., Djamgoz, M. B. A. \& Siddik, Z. H. Overview of the oncogenic signaling pathways in colorectal cancer: Mechanistic insights. Seminars in Cancer Biology 58, 65-79 (2019). 
9. Morkel, M., Riemer, P., Bläker, H. \& Sers, C. Similar but different: distinct roles for KRAS and BRAF oncogenes in colorectal cancer development and therapy resistance. Oncotarget 6, 20785-20800 (2015).

10. Cathomas, G. PIK3CA in Colorectal Cancer. Front Oncol 4, (2014).

11. Wicha, M. S., Liu, S. \& Dontu, G. Cancer Stem Cells: An Old Idea—A Paradigm Shift. Cancer Res 66, 1883-1890 (2006).

12. Vaiopoulos, A. G., Kostakis, I. D., Koutsilieris, M. \& Papavassiliou, A. G. Colorectal Cancer Stem Cells. STEM CELLS 30, 363-371 (2012).

13. Consensus molecular subtypes and the evolution of precision medicine in colorectal cancer-5.10.1038@nrc.2016.126.pdf.

14. Bae, J. M., Kim, J. H. \& Kang, G. H. Molecular Subtypes of Colorectal Cancer and Their Clinicopathologic Features, With an Emphasis on the Serrated Neoplasia Pathway. Archives of Pathology \& Laboratory Medicine 140, 406-412 (2016).

15. Müller, M. F., Ibrahim, A. E. K. \& Arends, M. J. Molecular pathological classification of colorectal cancer. Virchows Arch 469, 125-134 (2016).

16. Ciccia, A. \& Elledge, S. J. The DNA Damage Response: Making It Safe to Play with Knives. Molecular Cell 40, 179-204 (2010).

17. Lee, M. S., Menter, D. G. \& Kopetz, S. Right vs Left Colon Cancer Biology: Integrating Consensus Molecular Subtypes. JNCCN 15, 411-419 (2017). 
18. Mojarad, E. N., Kuppen, P. J., Aghdaei, H. A. \& Zali, M. R. The CpG island methylator phenotype (CIMP) in colorectal cancer. Gastroenterol Hepatol Bed Bench 6, 120-128 (2013).

19. Hanahan, D. \& Weinberg, R. A. Hallmarks of Cancer: The Next Generation. Cell 144, 646-674 (2011).

20. Dallas, N. A. et al. Chemoresistant colorectal cancer cells, the cancer stem cell phenotype, and increased sensitivity to insulin-like growth factor-I receptor inhibition. Cancer Res. 69, 1951-1957 (2009).

21. Zeuner, A., Todaro, M., Stassi, G. \& De Maria, R. Colorectal Cancer Stem Cells: From the Crypt to the Clinic. Cell Stem Cell 15, 692-705 (2014).

22. Danielsen, H. E. et al. Prognostic markers for colorectal cancer: estimating ploidy and stroma. Ann Oncol 29, 616-623 (2018).

23. Fotheringham, S., Mozolowski, G. A., Murray, E. M. A. \& Kerr, D. J. Challenges and solutions in patient treatment strategies for stage II colon cancer. Gastroenterol $\operatorname{Rep}($ Oxf) 7, 151-161 (2019).

24. PD-L1 expression in colorectal cancer is associated with microsatellite instability, BRAF mutation, medullary morphology and cytotoxic tumor-infiltrating lymphocytes - illiad.dll. 
25. Prognostic impact of programed cell death-1 (PD-1) and PD-ligand 1 (PD-L1) expression in cancer cells and tumor infiltrating lymphocytes in colorectal cancer art\%3A10.1186\%2Fs12943-016-0539-x.pdf.

26. Li, Y. et al. The Prognostic and Clinicopathological Roles of PD-L1 Expression in Colorectal Cancer: A Systematic Review and Meta-Analysis. Front Pharmacol 10, (2019).

27. Korehisa, S. et al. Clinical significance of programmed cell death-ligand 1 expression and the immune microenvironment at the invasive front of colorectal cancers with high microsatellite instability. International Journal of Cancer 142, 822-832 (2018).

28. Nojadeh, J. N., Behrouz Sharif, S. \& Sakhinia, E. Microsatellite instability in colorectal cancer. EXCLI J 17, 159-168 (2018).

29. Gragg, H., Harfe, B. D. \& Jinks-Robertson, S. Base composition of mononucleotide runs affects DNA polymerase slippage and removal of frameshift intermediates by mismatch repair in Saccharomyces cerevisiae. Mol. Cell. Biol. 22, 8756-8762 (2002).

30. Patel, M. et al. The relationship between right-sided tumour location, tumour microenvironment, systemic inflammation, adjuvant therapy and survival in patients undergoing surgery for colon and rectal cancer. Br J Cancer 118, 705-712 (2018).

31. Benson, A. B. et al. Colon Cancer, Version 1.2017, NCCN Clinical Practice Guidelines in Oncology. J Natl Compr Canc Netw 15, 370-398 (2017). 
32. Oikonomou, E., Koustas, E., Goulielmaki, M. \& Pintzas, A. BRAF vs RAS oncogenes: are mutations of the same pathway equal? differential signalling and therapeutic implications. Oncotarget 5, 11752-11777 (2014).

33. Reference, G. H. KRAS gene. Genetics Home Reference https://ghr.nlm.nih.gov/gene/KRAS.

34. Haigis, K. M. KRAS Alleles: The Devil Is In The Detail. Trends Cancer 3, 686-697 (2017).

35. Ahmed, S. et al. Primary Tumor Location and Survival in the General Population With Metastatic Colorectal Cancer. Clin Colorectal Cancer 17, e201-e206 (2018).

36. Reggiani Bonetti, L. et al. Clinical Impact and Prognostic Role of KRAS/BRAF/PIK3CA Mutations in Stage I Colorectal Cancer. Disease Markers https://www.hindawi.com/journals/dm/2018/2959801/ (2018) doi:10.1155/2018/2959801.

37. Phipps, A. I. et al. KRAS-mutation status in relation to colorectal cancer survival: the joint impact of correlated tumour markers. Br J Cancer 108, 1757-1764 (2013).

38. pubmeddev \& al, A.-M. F., et. Structural differences between valine-12 and aspartate-12 Ras proteins may modify carcinoma aggression. - PubMed - NCBI. https://www.ncbi.nlm.nih.gov/pubmed/10398103.

39. Molecular Biomarkers for the Evaluation of Colorectal Cancer - pdf. 
40. Lam, A. K.-Y., Chan, S. S.-Y. \& Leung, M. Synchronous colorectal cancer: Clinical, pathological and molecular implications. World J Gastroenterol 20, 6815-6820 (2014).

41. Dvorak, K. et al. Immunohistochemistry with the anti-BRAF V600E (VE1) antibody: impact of pre-analytical conditions and concordance with DNA sequencing in colorectal and papillary thyroid carcinoma. Pathology 46, 509-517 (2014).

42. Loree, J. M. et al. Classifying colorectal cancer by tumor location rather than sidedness highlights a continuum in mutation profiles and Consensus Molecular Subtypes. Clin Cancer Res 24, 1062-1072 (2018).

43. Schell, M. J. et al. A multigene mutation classification of 468 colorectal cancers reveals a prognostic role for APC. Nat Commun 7, (2016).

44. Understanding BRAF-Mutant Colorectal Cancer. ASCO Annual Meeting https://am.asco.org/daily-news/understanding-braf-mutant-colorectal-cancer (2016).

45. Hamada, T., Nowak, J. A. \& Ogino, S. PIK3CA mutation and colorectal cancer precision medicine. Oncotarget 8, 22305-22306 (2017).

46. Reference, G. H. PIK3CA gene. Genetics Home Reference https://ghr.nlm.nih.gov/gene/PIK3CA.

47. Nisa, L. et al. PIK3CA hotspot mutations differentially impact responses to MET targeting in MET-driven and non-driven preclinical cancer models. Mol Cancer 16, (2017). 
48. Wang, Q. et al. PIK3CA mutations confer resistance to first-line chemotherapy in colorectal cancer. Cell Death Dis 9, 1-11 (2018).

49. PIK3CA in colorectal cancer. ResearchGate https://www.researchgate.net/publication/260761852_PIK3CA_in_colorectal_cancer.

50. Lee, M. S., Menter, D. G. \& Kopetz, S. Right Versus Left Colon Cancer Biology: Integrating the Consensus Molecular Subtypes. J Natl Compr Canc Netw 15, 411419 (2017).

51. Meguid, R. A., Slidell, M. B., Wolfgang, C. L., Chang, D. C. \& Ahuja, N. Is There a Difference in Survival Between Right-Versus Left-Sided Colon Cancers? Ann Surg Oncol 15, 2388-2394 (2008).

52. Lee, M. S. et al. Association of primary $\left(1^{\circ}\right)$ site and molecular features with progression-free survival (PFS) and overall survival (OS) of metastatic colorectal cancer (mCRC) after anti-epidermal growth factor receptor ( $\alpha$ EGFR) therapy. J. Clin. Oncol. 34, (2016).

53. Mik, M., Berut, M., Dziki, L., Trzcinski, R. \& Dziki, A. Right- and left-sided colon cancer - clinical and pathological differences of the disease entity in one organ. Archives of Medical Science: AMS 13, 157 (2017).

54. New Studies Offer Insight Into Implications of Left- Versus Right-Sided Primary Tumor Location in CRC. Gastrointestinal Cancers Symposium 
https://gicasym.org/daily-news/new-studies-offer-insight-implications-left-versusright-sided-primary-tumor-location-crc (2017).

55. Colorectal Cancer Survival Linked to Primary Tumor Location. National Cancer Institute https://www.cancer.gov/news-events/cancer-currents-blog/2016/colorectalsurvival-location.

56. Colorectal Cancer Stages. https://www.cancer.org/cancer/colon-rectalcancer/detection-diagnosis-staging/staged.html.

57. Fleming, M., Ravula, S., Tatishchev, S. F. \& Wang, H. L. Colorectal carcinoma: Pathologic aspects. J Gastrointest Oncol 3, 153-173 (2012).

58. Adenocarcinoma of colon. http://www.pathologyoutlines.com/topic/colontumoradenocarcinoma.html.

59. Chemotherapy for Colorectal Cancer. WebMD https://www.webmd.com/colorectalcancer/chemotherapy.

60. Leucovorin - Chemotheray Drugs - Chemocare. http://chemocare.com/chemotherapy/drug-info/Leucovorin.aspx.

61. Zaanan, A. et al. Role of Deficient DNA Mismatch Repair Status in Patients With Stage III Colon Cancer Treated With FOLFOX Adjuvant Chemotherapy: A Pooled Analysis From 2 Randomized Clinical Trials. JAMA Oncol 4, 379-383 (2018). 
62. Oliveira, A. F., Bretes, L. \& Furtado, I. Review of PD-1/PD-L1 Inhibitors in Metastatic dMMR/MSI-H Colorectal Cancer. Front Oncol 9, 396 (2019).

63. USCS Data Visualizations. https://gis.cdc.gov/grasp/USCS/DataViz.html.

64. Olsabeck, T. Michigan Cancer Atlas 2019. 60.

65. Durko, L. \& Malecka-Panas, E. Lifestyle Modifications and Colorectal Cancer. Curr Colorectal Cancer Rep 10, 45-54 (2014).

66. Johnson, C. M. et al. Meta-analyses of Colorectal Cancer Risk Factors. Cancer Causes Control 24, 1207-1222 (2013).

67. What Are the Risk Factors for Colorectal Cancer? |CDC. https://www.cdc.gov/cancer/colorectal/basic_info/risk_factors.htm (2019).

68. Colon cancer - Symptoms and causes. Mayo Clinic https://www.mayoclinic.org/diseases-conditions/colon-cancer/symptoms-causes/syc20353669.

69. Mack, J. Almost a third of Michigan adults are obese; see percent in your county. mlive https://www.mlive.com/news/2019/04/almost-a-third-of-michigan-adults-areobese-see-percent-in-your-county.html (2019).

70. Yu, Y. et al. The long-term survival characteristics of a cohort of colorectal cancer patients and baseline variables associated with survival outcomes with or without time-varying effects. BMC Medicine 17, 150 (2019). 
71. Jauhri, M. et al. Prevalence and coexistence of KRAS, BRAF, PIK3CA, NRAS, TP53, and APC mutations in Indian colorectal cancer patients: Next-generation sequencing-based cohort study. Tumour Biol. 39, 1010428317692265 (2017).

72. Hunt, J. L. \& Finkelstein, S. D. Microdissection Techniques for Molecular Testing in Surgical Pathology. Archives of Pathology \& Laboratory Medicine 128, 1372-1378 (2004).

73. Abstracting Keys | SEER Training. https://training.seer.cancer.gov/colorectal/abstract-code-stage/keys.html.

74. Rosty, C. et al. PIK3CA Activating Mutation in Colorectal Carcinoma: Associations with Molecular Features and Survival. PLOS ONE 8, e65479 (2013).

75. Catasus, L., Gallardo, A., Cuatrecasas, M. \& Prat, J. PIK3CA mutations in the kinase domain (exon 20) of uterine endometrial adenocarcinomas are associated with adverse prognostic parameters. Mod Pathol 21, 131-139 (2008).

76. Kim, S.-E. et al. Sex- and gender-specific disparities in colorectal cancer risk. World J Gastroenterol 21, 5167-5175 (2015).

77. Larki, P. et al. Coexistence of KRAS and BRAF Mutations in Colorectal Cancer: A Case Report Supporting The Concept of Tumoral Heterogeneity. Cell J 19, 113-117 (2017). 
78. Liu, J. et al. Predictive and Prognostic Implications of Mutation Profiling and Microsatellite Instability Status in Patients with Metastatic Colorectal Carcinoma. Gastroenterol Res Pract 2018, 4585802 (2018).

79. Sartore-Bianchi, A., Loupakis, F., Argilés, G. \& Prager, G. W. Challenging chemoresistant metastatic colorectal cancer: therapeutic strategies from the clinic and from the laboratory. Ann Oncol 27, 1456-1466 (2016). 
A Figures and Tables

\section{A.1 Incidence of Colorectal Cancer in the Upper Peninsula of Michigan.}

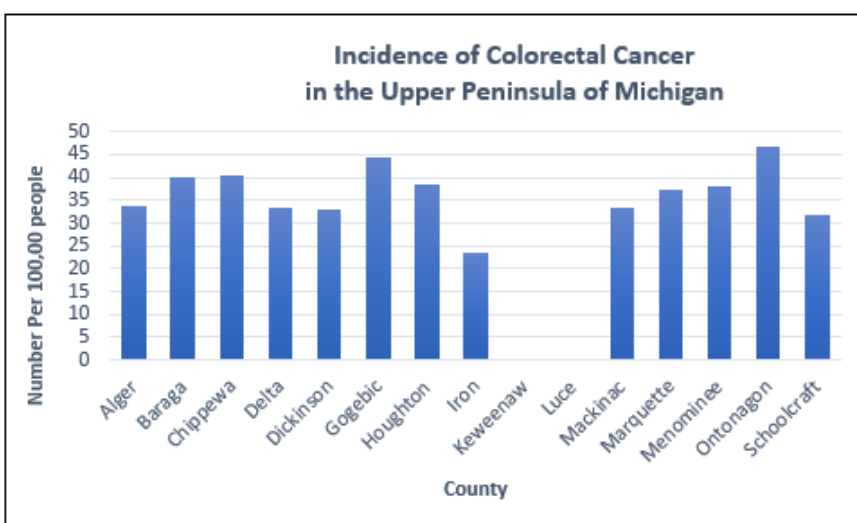

Figure A.l. Incidence of Colorectal Cancer By County in the Upper Peninsula of Michigan. This chart depicts the number of residents diagnosed with colorectal cancer by county during the 2012-2016 surveillance period. Counties with fewer than 20 cases were not included in the data set. Source: Michigan Cancer Atlas \& Michigan Cancer Surveillance Program.

\section{A.2 Percent of Upper Michigan Residents by County Diagnosed with Advanced Disease.}

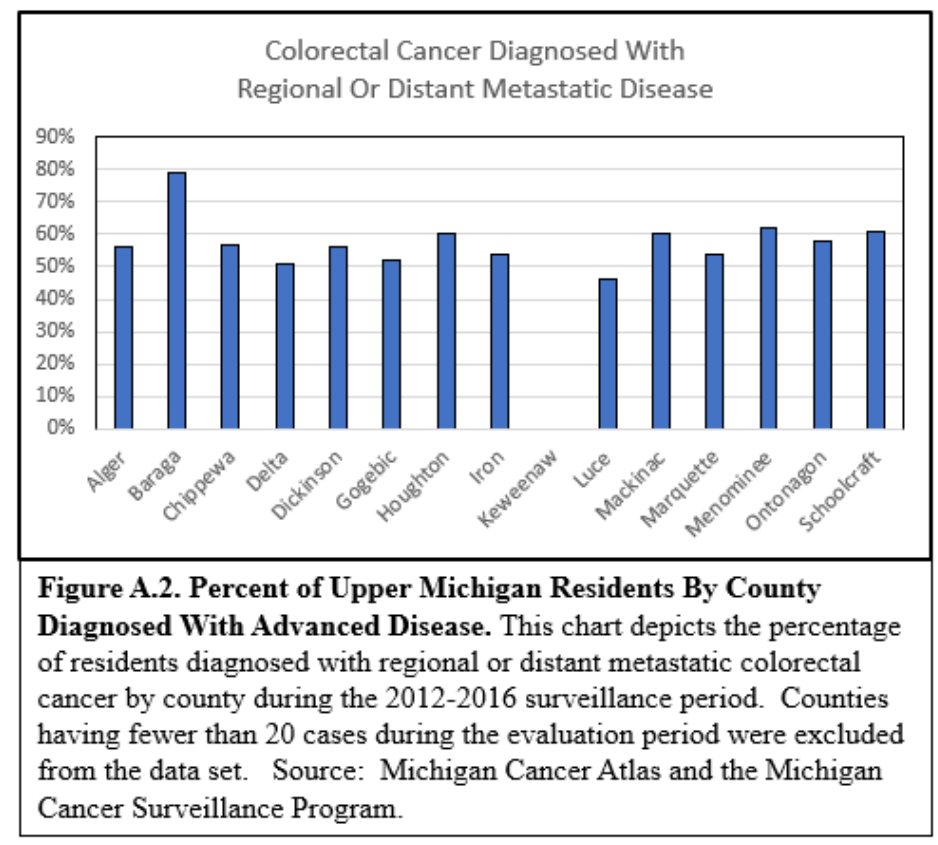




\section{A.3 Patient Demographics \& Anatomic Distribution of Primary CRC Malignancies.}

\section{Table A.1. Patient Demographics and Anatomic Distribution of Primary}

Colorectal Malignancies.

\begin{tabular}{|l|l|l|l|l|l|l|l|l|}
\hline $\begin{array}{l}\text { Primary Site } \\
\text { of } \\
\text { Malignancy } \\
\text { of } \\
\text { Subjects } \\
\text { (n=541) }\end{array}$ & $\begin{array}{l}\text { \%o of } \\
\text { Total } \\
\text { Cohort }\end{array}$ & $\begin{array}{l}\# \\
\text { Males }\end{array}$ & $\begin{array}{l}\text { Mo } \\
\text { Males }\end{array}$ & $\begin{array}{l}\text { Average } \\
\text { Age }\end{array}$ & $\begin{array}{l}\# \\
\text { Females }\end{array}$ & $\begin{array}{l}\text { \%omales } \\
\text { Femge }\end{array}$ & $\begin{array}{l}\text { Average } \\
\text { Age }\end{array}$ \\
\hline Cecum & 74 & $14 \%$ & 31 & $42 \%$ & 69 & 43 & $58 \%$ & 73 \\
\hline $\begin{array}{l}\text { Ascending } \\
\text { Colon }\end{array}$ & 68 & $12 \%$ & 29 & $43 \%$ & 70 & 39 & $57 \%$ & 74 \\
\hline $\begin{array}{l}\text { Hepatic } \\
\text { flexure }\end{array}$ & 11 & $2 \%$ & 9 & $82 \%$ & 71 & 2 & $18 \%$ & 65 \\
\hline $\begin{array}{l}\text { Transverse } \\
\text { Colon }\end{array}$ & 58 & $11 \%$ & 35 & $60 \%$ & 69 & 23 & $40 \%$ & 72 \\
\hline $\begin{array}{l}\text { Splenic } \\
\text { Flexure }\end{array}$ & 13 & $2 \%$ & 7 & $54 \%$ & 65 & 6 & $46 \%$ & 67 \\
\hline $\begin{array}{l}\text { Descending } \\
\text { Colon }\end{array}$ & 14 & $3 \%$ & 4 & $29 \%$ & 69 & 10 & $71 \%$ & 74 \\
\hline $\begin{array}{l}\text { Sigmoid } \\
\text { Colon }\end{array}$ & 99 & $18 \%$ & 65 & $66 \%$ & 62 & 34 & $34 \%$ & 64 \\
\hline Rectum & 121 & $22 \%$ & 77 & $64 \%$ & 67 & 44 & $36 \%$ & 67 \\
\hline Colon, NOS & 34 & $22 \%$ & 21 & $62 \%$ & 66 & 13 & $38 \%$ & 65 \\
\hline Left colon & 4 & $1 \%$ & 2 & $50 \%$ & 64 & 2 & $50 \%$ & 61 \\
\hline Right colon & 28 & $5 \%$ & 14 & $50 \%$ & 68 & 14 & $50 \%$ & 76 \\
\hline $\begin{array}{l}\text { Ileocecal } \\
\text { valve }\end{array}$ & 6 & $1 \%$ & 3 & $50 \%$ & 73 & 3 & $50 \%$ & 74 \\
\hline Appendix & 7 & $1 \%$ & 5 & $71 \%$ & 60 & 2 & $29 \%$ & 40 \\
\hline $\begin{array}{l}\text { Overlapping } \\
\text { Lesion }\end{array}$ & 3 & $.05 \%$ & 1 & $33 \%$ & 56 & 2 & $67 \%$ & 77 \\
\hline $\begin{array}{l}\text { Anal-rectal } \\
\text { junction }\end{array}$ & 1 & $0.1 \%$ & 0 & 0 & & 1 & $100 \%$ & 51 \\
\hline
\end{tabular}




\section{A.4 Anatomic Distribution of Primary Colorectal Cancer in Patient Cohort.}

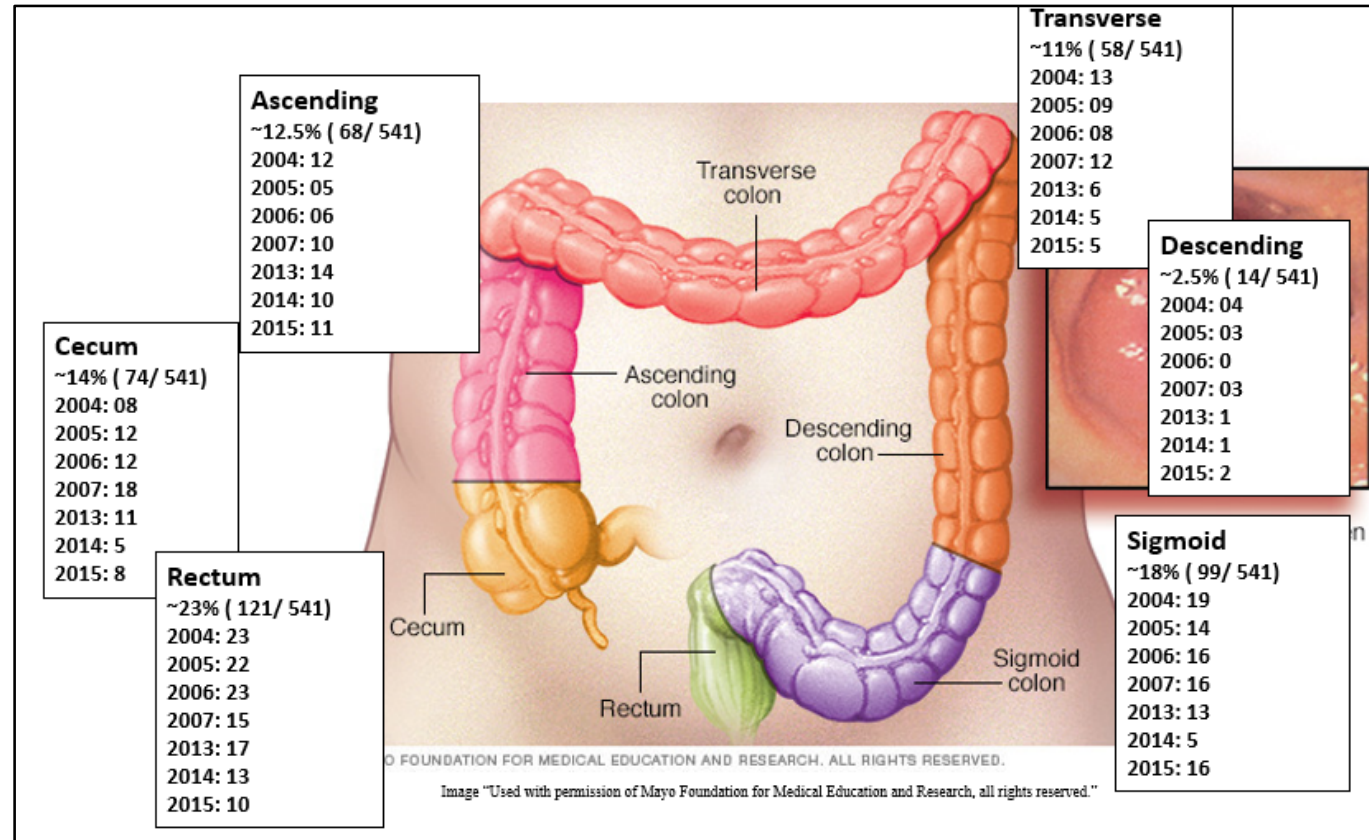

Figure A.3. Anatomic Distribution of Primary Colorectal Cancer in Patient Cohort.

Image used with permission of Mayo Foundation for Medical Education and Research, all rights reserved. 


\section{A.5 AJCC $\left(7^{\text {th }}\right.$ ed) Staging by Anatomic Site of Primary Malignancy.}

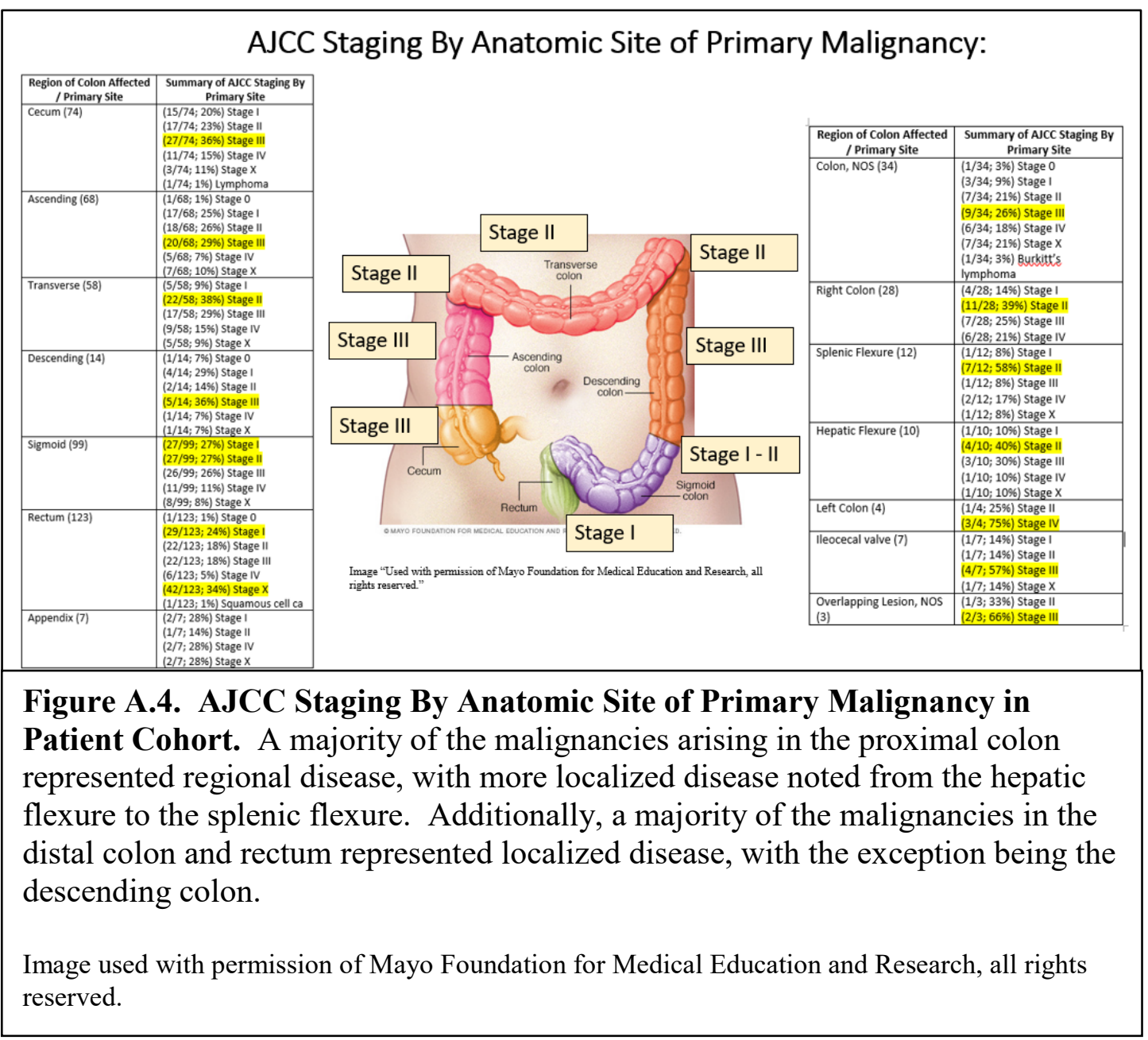




\section{A.6 Classification of Colonoscopies and Mechanism for Detection of CRC for Patients In This Cohort.}

\section{Table A.2. Classification of Colonoscopies and Mechanism for Detection of CRC For Patients in this Cohort. Gastroenterologist procedural notes and cancer registry data classified the colonoscopies performed on patients in this study and provided insight regarding the mode of diagnosis for the CRC samples analyzed in this study.}

\begin{tabular}{|l|l|l|}
\hline Colonoscopy, NOS & 88 & $16 \%$ \\
\hline Screening Colonoscopy & 13 & $2 \%$ \\
\hline Screening Colonoscopy with Biopsy & 7 & $1 \%$ \\
\hline Diagnostic Colonoscopy & 132 & $24 \%$ \\
\hline Diagnostic Colonoscopy with Biopsy & 130 & $24 \%$ \\
\hline EGD and Colonoscopy & 14 & $2 \%$ \\
\hline EGD and Colonoscopy with Biopsies & 25 & $5 \%$ \\
\hline Sigmoidoscopy & 5 & $1 \%$ \\
\hline Abnormal CT of Abdomen & 1 & $0.2 \%$ \\
\hline $\begin{array}{l}\text { Bilateral Pulmonary Nodules and } \\
\text { Large Bowel Obstruction }\end{array}$ & 1 & $0.2 \%$ \\
\hline Abnormal Virtual Colonoscopy & 1 & $0.2 \%$ \\
\hline CT-guided Biopsy & 1 & $0.2 \%$ \\
\hline Colon and Liver Biopsy & 1 & $0.2 \%$ \\
\hline Exploratory Laparotomy & 7 & $1 \%$ \\
\hline $\begin{array}{l}\text { Appendix, omentum, peritoneum } \\
\text { biopsy }\end{array}$ & 1 & $0.2 \%$ \\
\hline Patient unable to tolerate prep & 3 & $0.5 \%$ \\
\hline Colonoscopy unsuccessful, NOS & 1 & $0.2 \%$ \\
\hline Unknown / None & 110 & $20 \%$ \\
\hline
\end{tabular}




\section{A.7 Distribution of Anatomic Site of Primary Malignancy in Patient Cohort.}

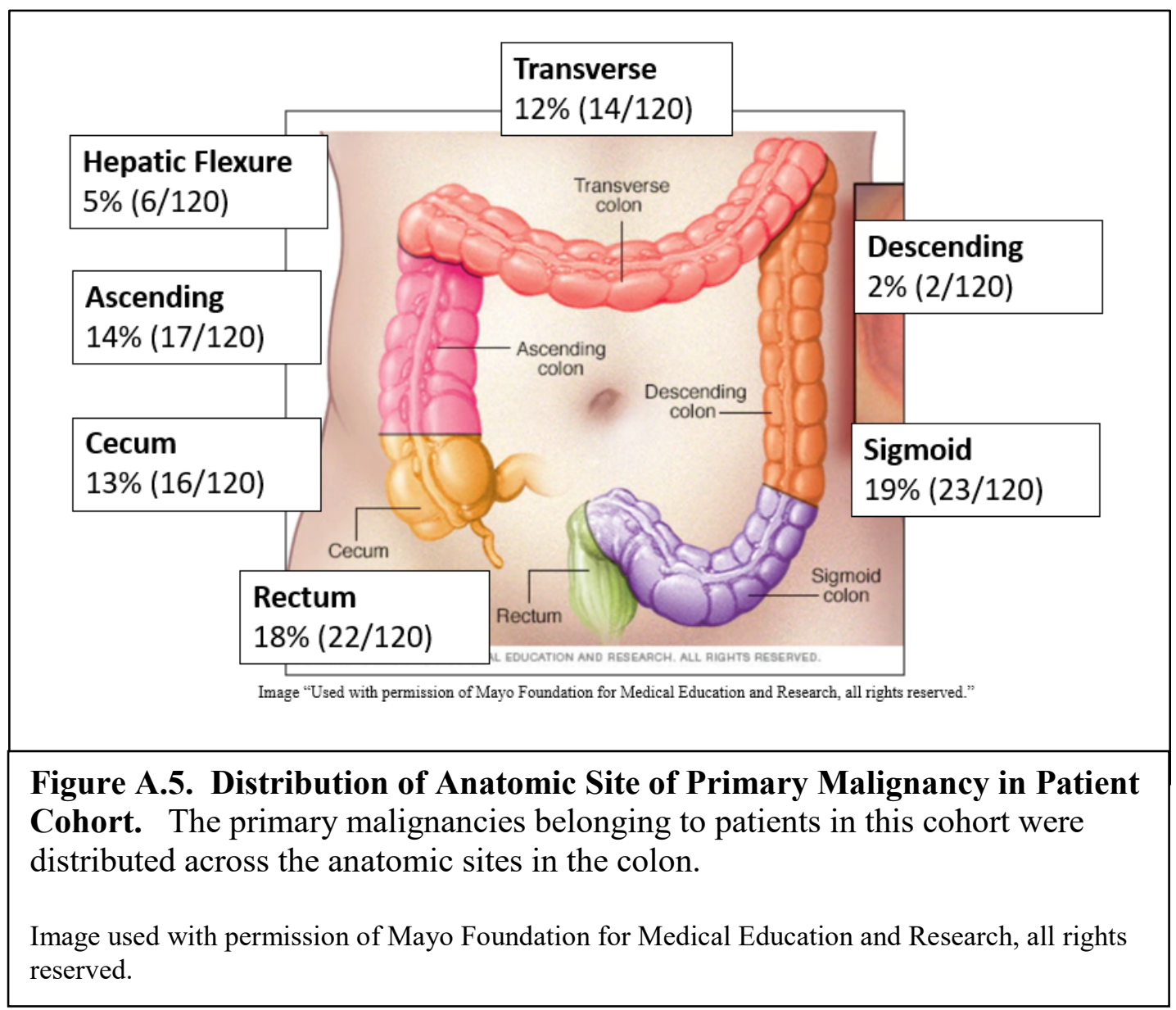




\section{A.8 Distribution of Primary Malignancies in the Proximal vs. Distal Colon for Patient Cohort.}

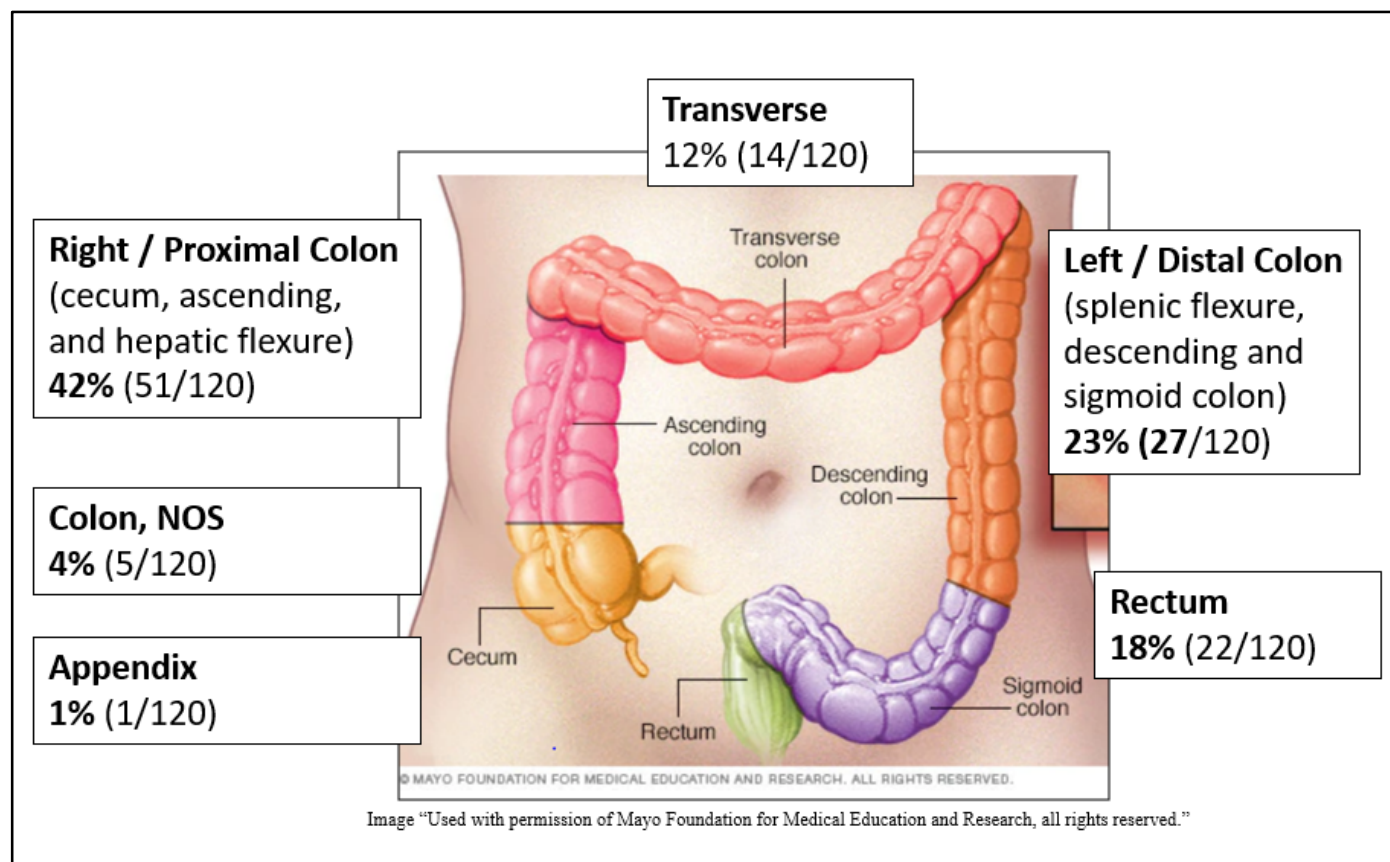

Figure A.6. Distribution of Primary Malignancies in the Proximal vs. Distal Colon for Patient Cohort. A majority of the malignancies belonging to patients in this cohort arose in the proximal colon. While patients and matched samples were randomly selected for mutation studies, the distribution of primary malignancies is representative of the larger cohort's retrospective review.

Image used with permission of Mayo Foundation for Medical Education and Research, all rights reserved. 


\section{A.9 AJCC Staging by Primary Site for 120 Patient Cohort.}

\begin{tabular}{|c|c|}
\hline \multicolumn{2}{|c|}{$\begin{array}{l}\text { Table A.3. AJCC Staging by Primary } \\
\text { Site for } 120 \text { Patient Cohort. } \\
\text { For this subset of patients, a majority of } \\
\text { the malignancies arising in the the cecum, } \\
\text { sigmoid colon and rectum represented } \\
\text { regional disease. Conversely, those } \\
\text { arising in the ascending and transverse } \\
\text { colon represented localized disease. }\end{array}$} \\
\hline $\begin{array}{c}\text { Region of Colon } \\
\text { Affected / Primary } \\
\text { Site }\end{array}$ & $\begin{array}{l}\text { Summary of AICC Staging By } \\
\text { Primary Site }\end{array}$ \\
\hline Cecum (16) & $\begin{array}{l}\text { Stage I: } 25 \%(4 / 16) \\
\text { Stage II: } 25 \%(4 / 16) \\
\text { Stage III: } 44 \%(7 / 16) \\
\text { Stage IV: } \quad 6 \%(1 / 16)\end{array}$ \\
\hline Ascending (17) & $\begin{array}{l}\text { Stage I: } 41 \%(7 / 17) \\
\text { Stage II: } 29 \%(5 / 17) \\
\text { Stage III: } 24 \% \%(4 / 17) \\
\text { Stage IV: } \quad 6 \%(1 / 17)\end{array}$ \\
\hline Transverse (14) & $\begin{array}{l}\text { Stage I: } 14 \%(2 / 14) \\
\text { Stage II: } 50 \%(7 / 14) \\
\text { Stage III: } 29 \%(4 / 14) \\
\text { Stage IV: } \quad 7 \%(1 / 14)\end{array}$ \\
\hline Descending (2) & $\begin{array}{l}\text { Stage I: } 50 \%(1 / 2) \\
\text { Stage III: } 50 \%(1 / 2)\end{array}$ \\
\hline Sigmoid (23) & $\begin{array}{l}\text { Stage I: } 48 \%(11 / 23) \\
\text { Stage II: } 17 \%(4 / 23) \\
\text { Stage III: } 30 \%(7 / 23) \\
\text { Stage IV: } 4 \%(1 / 23)\end{array}$ \\
\hline Rectum (22) & $\begin{array}{l}\text { Stage I: } 18 \%(4 / 22) \\
\text { Stage II: } 32 \%(7 / 22) \\
\text { Stage III: } 45 \%(10 / 22) \\
\text { Stage IV: } \quad 5 \%(1 / 22)\end{array}$ \\
\hline Appendix (1) & Stage $\mathrm{I}=100 \%(1 / 1)$ \\
\hline Colon, NOS (5) & $\begin{array}{l}\text { Stage I: } \quad 20 \%(1 / 5) \\
\text { Stage II: } 80 \%(4 / 5)\end{array}$ \\
\hline Right Colon (9) & $\begin{array}{l}\text { Stage I: } 33 \%(3 / 9) \\
\text { Stage II: } 67 \%(6 / 9)\end{array}$ \\
\hline
\end{tabular}




\title{
A.10 Correlation of KRAS G12x Targeted Region Mutations with Clinicopathological Data for the Patient Cohort.
}

\author{
Table A.4. Correlation of KRAS G12x Targeted Region Mutations with \\ Clinicopathological Data for the Patient Cohort. \\ KRAS G12x was the most common KRAS mutation identified in our cohort. From a \\ clinico-pathological perspective, this mutation was observed in a higher frequency in \\ primary tumors arising in the proximal colon. The KRAS G12x mutation was primarily \\ identified in Grade 2, Stage II adenocarcinoma.
}

\begin{tabular}{|c|c|c|c|c|c|c|}
\hline \multirow{2}{*}{$\begin{array}{l}\text { KRAS } \\
\text { Mutation }\end{array}$} & \multicolumn{3}{|c|}{ Patient Demographics } & \multirow{2}{*}{ WHO Grade } & \multirow{2}{*}{$\begin{array}{c}\text { AJCC } \\
\text { Staging }\end{array}$} & \multirow[b]{2}{*}{ Cause of Death } \\
\hline & Source & Gender & Age & & & \\
\hline \multicolumn{7}{|l|}{ G12x } \\
\hline & Cecum & Male & 70 & Grade 2 & $\begin{array}{l}\text { T3N2M1 } \\
\text { Stage IV }\end{array}$ & Cancer-related \\
\hline & Rectum & Male & 35 & Grade 2 & $\begin{array}{l}\text { T3N1M0 } \\
\text { Stage III }\end{array}$ & Unknown \\
\hline & Ascending & Male & 50 & Grade 2 & $\begin{array}{l}\text { T2N1M0 } \\
\text { Stage III }\end{array}$ & Not cancer-related \\
\hline & Transverse & Female & 66 & Grade 2 & $\begin{array}{l}\text { T3N1M0 } \\
\text { Stage III }\end{array}$ & Cancer-related \\
\hline & Sigmoid & Female & 74 & Grade 2 & $\begin{array}{l}\text { T4N1Mx } \\
\text { Stage III }\end{array}$ & Cancer-related \\
\hline & Transverse & Female & 66 & Grade 2 & $\begin{array}{l}\text { T3N1M1 } \\
\text { Stage IV }\end{array}$ & Cancer-related \\
\hline & Ascending & Female & 90 & Grade 3 & $\begin{array}{l}\text { T3N2M0 } \\
\text { Stage III }\end{array}$ & Unknown \\
\hline & Ascending & Female & 48 & Grade 2 & $\begin{array}{c}\text { T3N0M0 } \\
\text { Stage II }\end{array}$ & Not applicable \\
\hline & Rectum & Female & 83 & Grade 2 & $\begin{array}{c}\text { T3N0M0 } \\
\text { Stage II } \\
\end{array}$ & Not applicable \\
\hline & Colon & Female & 73 & Grade 2 & $\begin{array}{c}\text { T1N0M0 } \\
\text { Stage I }\end{array}$ & Unknown \\
\hline & Sigmoid & Male & 68 & Grade 3 & $\begin{array}{c}\text { T1N0M0 } \\
\text { Stage I }\end{array}$ & Cancer-related \\
\hline & Ascending & Female & 83 & Grade 2 & $\begin{array}{c}\text { T2N0M0 } \\
\text { Stage I }\end{array}$ & Not cancer-related \\
\hline & Ascending & Male & 67 & Grade 2 & $\begin{array}{c}\text { T2N0M0 } \\
\text { Stage I }\end{array}$ & Unknown \\
\hline & Transverse & Female & 69 & Grade 2 & $\begin{array}{c}\text { T3N0M0 } \\
\text { Stage II }\end{array}$ & Not cancer-related \\
\hline & Transverse & Female & 76 & Grade 4 & $\begin{array}{c}\text { T3N0M0 } \\
\text { Stage II } \\
\end{array}$ & Cancer-related \\
\hline & Colon, NOS & Male & 75 & Grade 2 & $\begin{array}{c}\text { T3N0M0 } \\
\text { Stage II }\end{array}$ & Not cancer-related \\
\hline & Sigmoid & Male & 64 & Grade 2 & $\begin{array}{c}\text { T3N0M0 } \\
\text { Stage II } \\
\end{array}$ & Unknown \\
\hline & Cecum & Female & 55 & Grade 2 & $\begin{array}{c}\text { T2N0M0 } \\
\text { Stage I }\end{array}$ & Not applicable \\
\hline
\end{tabular}




\section{A.11 Correlation of KRAS G12x Targeted Region Mutations (continued)}

Table A.4. Correlation of KRAS G12x Targeted Region Mutations with Clinicopathological Data for the Patient Cohort (continued)

\begin{tabular}{|c|c|c|c|c|c|c|}
\hline \multirow{2}{*}{$\begin{array}{c}\text { KRAS } \\
\text { Mutation }\end{array}$} & \multicolumn{3}{|c|}{ Patient Demographics } & \multirow{2}{*}{$\begin{array}{l}\text { WHO } \\
\text { Grade }\end{array}$} & \multirow{2}{*}{$\begin{array}{c}\text { AJCC } \\
\text { Staging } \\
\end{array}$} & \multirow{2}{*}{ Cause of Death } \\
\hline & Source & Gender & Age & & & \\
\hline \multicolumn{7}{|l|}{ G12x } \\
\hline & Rectum & Male & 72 & Grade 2 & $\begin{array}{c}\text { T1N0M0 } \\
\text { Stage I }\end{array}$ & unknown \\
\hline & Cecum & Male & 62 & Grade 3 & $\begin{array}{l}\text { T3N0M0 } \\
\text { Stage II }\end{array}$ & Unknown \\
\hline & Cecum & Male & 57 & Grade 3 & $\begin{array}{c}\text { T3N0M0 } \\
\text { Stage II }\end{array}$ & Unknown \\
\hline & Cecum & Male & 88 & Grade 2 & $\begin{array}{c}\text { T2N0M0 } \\
\text { Stage I }\end{array}$ & Cancer-related \\
\hline & $\begin{array}{l}\text { Splenic } \\
\text { flexure }\end{array}$ & Male & 89 & Grade 2 & $\begin{array}{l}\text { T4N0M0 } \\
\text { Stage II }\end{array}$ & Cancer-related \\
\hline & Appendix & Male & 60 & Grade 2 & $\begin{array}{c}\text { T1N0M0 } \\
\text { Stage I }\end{array}$ & Not cancer-related \\
\hline & $\begin{array}{l}2004- \\
\text { rectum }\end{array}$ & Female & 90 & Grade 2 & $\begin{array}{l}\text { T3NxMx } \\
\text { Stage II }\end{array}$ & Cancer-related \\
\hline & $\begin{array}{c}\text { 2005- } \\
\text { Rectum }\end{array}$ & & & Grade 2 & $\begin{array}{l}\text { T3NxMx } \\
\text { Stage II }\end{array}$ & $\begin{array}{c}\text { See above- } \\
\text { recurrent cancer }\end{array}$ \\
\hline & $\begin{array}{c}\text { Left colon, } \\
\text { NOS } \\
\end{array}$ & Male & 78 & Grade 2 & $\begin{array}{l}\text { T4N2M0 } \\
\text { Stage III }\end{array}$ & Cancer-related \\
\hline & Sigmoid & Female & 74 & Grade 3 & $\begin{array}{c}\text { T2N0Mx } \\
\text { Stage I }\end{array}$ & Unknown \\
\hline
\end{tabular}




\section{A.12 Correlation of KRAS G13x Targeted Region Mutations with Clinicopathological Data for the Patient Cohort.}

Table A.5. Correlation of KRAS G13x Targeted Region Mutations with Clinicopathological Data for the Patient Cohort

KRAS G13x was the second most frequently identified KRAS mutation in our cohort. From a clinico-pathological perspective, this mutation was observed in a higher frequency in primary tumors arising in the distal colon. The KRAS G13x mutation was primarilyidentified in Grade 2, Stage III adenocarcinoma.

\begin{tabular}{|c|c|c|c|c|c|c|}
\hline $\begin{array}{l}\text { KRAS } \\
\text { Mutation }\end{array}$ & \begin{tabular}{|l} 
Patient De \\
Source \\
\end{tabular} & $\begin{array}{l}\text { mograph } \\
\text { Gender }\end{array}$ & $\begin{array}{l}\text { lics } \\
\text { Age } \\
\end{array}$ & \begin{tabular}{|l|} 
WHO \\
Histological \\
Grade \\
\end{tabular} & \begin{tabular}{|l} 
AJCC \\
Staging
\end{tabular} & Cause of Death \\
\hline \multirow[t]{11}{*}{ G13x } & $\begin{array}{l}\text { Hepatic } \\
\text { flexure }\end{array}$ & Female & 63 & Grade 2 & \begin{tabular}{|l|} 
T4N1M0 \\
Stage III \\
\end{tabular} & Not applicable \\
\hline & Sigmoid & Female & 45 & Grade 2 & $\begin{array}{l}\text { T3N1M0 } \\
\text { Stage III } \\
\end{array}$ & Unknown \\
\hline & Cecum & Female & 77 & Grade 2 & $\begin{array}{l}\text { T2N1M0 } \\
\text { Stage III }\end{array}$ & Not cancer-related \\
\hline & Transverse & Male & 51 & Grade 2 & $\begin{array}{l}\text { T2N0M0 } \\
\text { Stage I } \\
\end{array}$ & Not applicable \\
\hline & \begin{tabular}{|l|} 
Splenic \\
flexure
\end{tabular} & Male & 65 & Grade 2 & $\begin{array}{l}\text { T2N0M0 } \\
\text { Stage I }\end{array}$ & Not applicable \\
\hline & Sigmoid & Male & 83 & Grade 2 & $\begin{array}{l}\text { T2N0M0 } \\
\text { Stage I }\end{array}$ & Unknown \\
\hline & $\begin{array}{l}\text { Hepatic } \\
\text { flexure }\end{array}$ & Male & 84 & Grade 2 & $\begin{array}{l}\text { T2N0M0 } \\
\text { Stage I }\end{array}$ & Cancer-related \\
\hline & \begin{tabular}{|l|} 
Splenic \\
flexure
\end{tabular} & Female & 67 & Grade 2 & $\begin{array}{l}\text { T4N0M0 } \\
\text { Stage II }\end{array}$ & Cancer-related \\
\hline & \begin{tabular}{|l|}
$05-$ \\
Sigmoid \\
\end{tabular} & Female & 70 & Grade 2 & $\begin{array}{l}\text { T3N2Mx } \\
\text { Stage III } \\
\end{array}$ & Cancer-related \\
\hline & \begin{tabular}{|l|}
$06-$ \\
Rectum \\
\end{tabular} & & & Grade 2 & $\begin{array}{l}\text { T3N2Mx } \\
\text { Stage III }\end{array}$ & $\begin{array}{l}\text { Same patient - } \\
\text { recurrent cancer }\end{array}$ \\
\hline & \begin{tabular}{|l|}
$07-$ \\
Rectum \\
\end{tabular} & & & Grade 2 & $\begin{array}{l}\text { T3N2Mx } \\
\text { Stage III }\end{array}$ & $\begin{array}{l}\text { Same patient - } \\
\text { recurrent cancer }\end{array}$ \\
\hline
\end{tabular}




\section{A.13 Correlation of KRAS G13x and Less Common Targeted Region Mutation with Clinicopathological Data for the Patient Cohort (continued).}

\begin{tabular}{|c|c|c|c|c|c|c|}
\hline $\begin{array}{l}\text { KRAS } \\
\text { Mutation }\end{array}$ & $\begin{array}{l}\text { Patient De } \\
\text { Source }\end{array}$ & $\begin{array}{l}\text { mograph } \\
\text { Gender }\end{array}$ & $\begin{array}{l}\text { ics } \\
\text { Age }\end{array}$ & \multirow{2}{*}{$\begin{array}{l}\text { WHO } \\
\text { Histological } \\
\text { Grade } \\
\text { Grade } 2\end{array}$} & \multirow{2}{*}{$\begin{array}{l}\text { AJCC } \\
\text { Staging } \\
\text { T1N0M0 } \\
\text { Stage I } \\
\end{array}$} & \multirow{2}{*}{\begin{tabular}{|l} 
Cause of Death \\
Cancer-related
\end{tabular}} \\
\hline $\begin{array}{l}\text { G12x \& } \\
\text { G13x }\end{array}$ & Ascending & Female & 86 & & & \\
\hline \multirow[t]{2}{*}{ A146x } & Ascending & Male & 53 & Grade 2 & \begin{tabular}{|l|} 
T3N2M1 \\
Stage IV \\
\end{tabular} & Cancer-related \\
\hline & Transverse & Male & 72 & Grade 2 & $\begin{array}{l}\text { T4N0M0 } \\
\text { Stage II } \\
\end{array}$ & Not cancer-related \\
\hline \multirow[t]{2}{*}{ K117x } & Rectum & Male & 68 & Grade 2 & \begin{tabular}{|l} 
T3N2M1 \\
Stage IV \\
\end{tabular} & $\begin{array}{l}\text { Cancer-related } \\
\text { COD } \\
\end{array}$ \\
\hline & Sigmoid & Male & 59 & Grade 3 & $\begin{array}{l}\text { T3N1M0 } \\
\text { Stage III }\end{array}$ & Unknown \\
\hline Q61x & Ascending & Male & 67 & Grade 2 & \begin{tabular}{|l|} 
T3N0M0 \\
Stage II \\
\end{tabular} & Not cancer-related \\
\hline A59x & Sigmoid & Male & 48 & Grade 3 & $\begin{array}{l}\text { T2N0M0 } \\
\text { Stage I }\end{array}$ & Unknown \\
\hline
\end{tabular}




\section{A.14 Correlation of BRAF V600E Mutation with Clinicopathological Data for the Patient Cohort.}

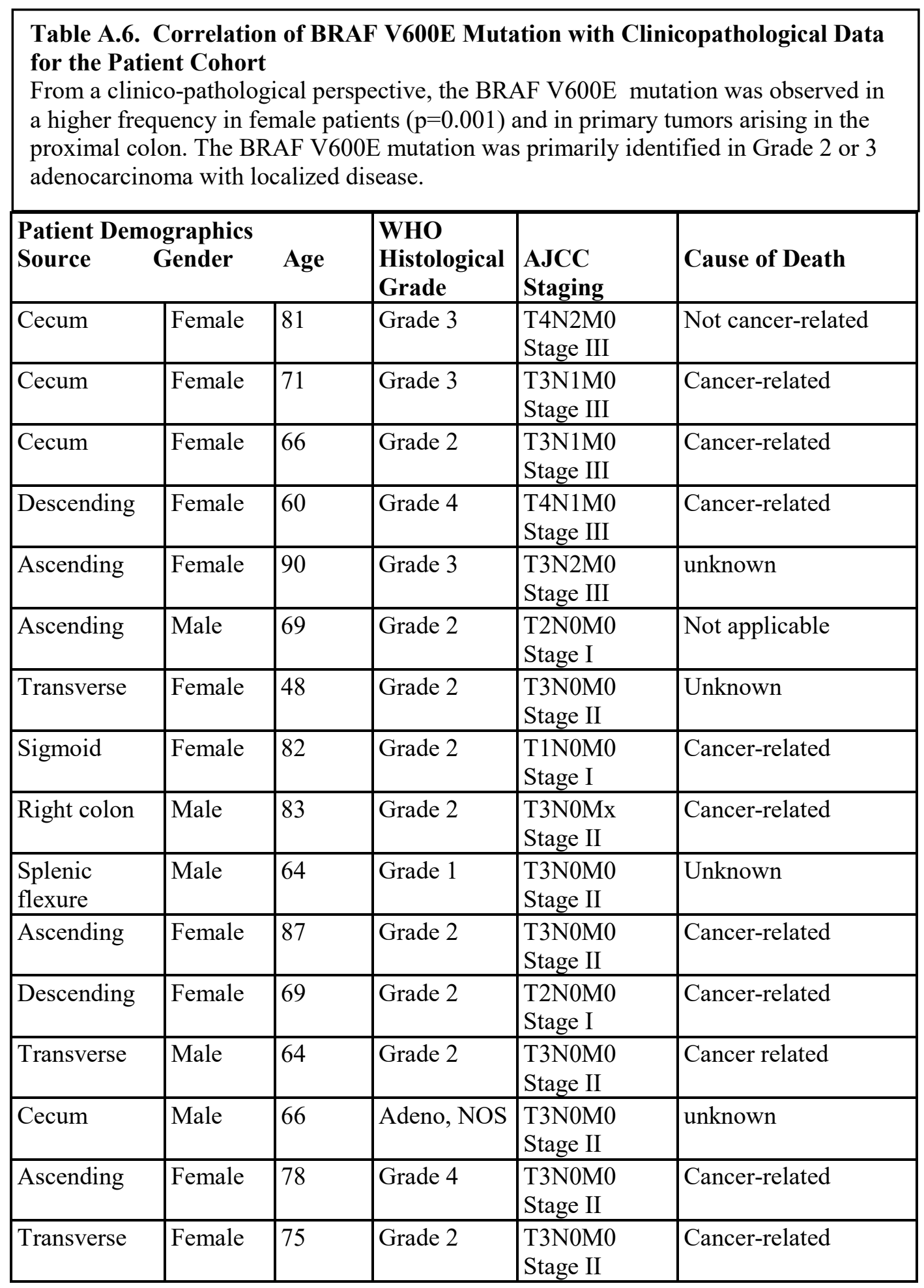




\section{A.15 Correlation of BRAF V600E Mutation with Clinicopathological Data for Patient Cohort (continued).}

Table A.6. Correlation of BRAF V600E Mutation with Clinicopathological Data for the Patient Cohort (continued)

\begin{tabular}{|c|c|c|c|c|c|}
\hline $\begin{array}{l}\text { Patient Dem } \\
\text { Source }\end{array}$ & $\begin{array}{l}\text { ographic } \\
\text { Gender }\end{array}$ & Age & \begin{tabular}{|l|} 
WHO \\
Histological \\
Grade \\
\end{tabular} & $\begin{array}{l}\text { AJCC } \\
\text { Staging }\end{array}$ & Cause of Death \\
\hline Transverse & Female & 83 & Grade 3 & $\begin{array}{l}\text { T4N0M0 } \\
\text { Stage II }\end{array}$ & Not cancer-related \\
\hline Cecum & Female & 83 & Grade 3 & \begin{tabular}{|l|} 
T3N0M0 \\
Stage II
\end{tabular} & Cancer-related \\
\hline $\begin{array}{l}\text { Splenic } \\
\text { flexure }\end{array}$ & Female & 87 & Grade 2 & $\begin{array}{l}\text { T3N0Mx } \\
\text { Stage II }\end{array}$ & Not cancer-related \\
\hline Right colon & Female & 80 & \begin{tabular}{|l} 
synch \\
$\# 2$ - Grade 2 \\
$\# 6$ - Grade 1 \\
Recurrent \\
resection \& \\
biopsy \\
Grade 3
\end{tabular} & $\begin{array}{l}\text { T3N0Mx } \\
\text { Stage II } \\
\text { T1N0Mx } \\
\text { Stage I } \\
\\
\text { T3N0Mx } \\
\text { Stage II }\end{array}$ & Cancer-related \\
\hline $\begin{array}{l}\text { Synchronous } \\
\text { Ascending } \\
\text { (block \#3) } \\
\text { Transverse } \\
\text { (block \#7) }\end{array}$ & Female & 70 & $\begin{array}{l}\text { Sync } \\
\# 3 \text {-Grade } 3 \\
\# 7-\text { Grade } 2\end{array}$ & $\begin{array}{l}\text { T2N0M0 } \\
\text { Stage I }\end{array}$ & Not applicable \\
\hline
\end{tabular}




\section{A.16 Correlation of NRAS Targeted Region Mutations with Clinicopathological Data for the Patient Cohort.}

Table A.7. Correlation of NRAS Targeted Region Mutations with
Clinicopathological Data for the Patient Cohort
NRAS mutations in codon 61were the most frequently NRAS mutations identified
in our cohort. NRAS mutations were observed in a higher frequency in male
patients and were slightly more prevalent in primary tumors arising in the proximal
colon. NRAS mutations primarily identified in Grade 2 adenocarcinoma with
localized disease.




\section{A.17 Correlation of PIK3CA Targeted Region Mutations with Clinicopathological Data for the Patient Cohort.}

\section{Table A.8. Correlation of PIK3CA Targeted Region Mutations with Clinicopathological Data for the Patient Cohort}

PIK3CA mutations in exons 9 and 20 were the most frequently PIK3CA mutations identified in our cohort. PIK3CA mutations were observed in equally among both genders and were identified in higher frequencies in primary tumors arising in the proximal colon. PIK3CA mutations associated with Grade 2, AJCC Stage II adenocarcinoma in our cohort.

\begin{tabular}{|c|c|c|c|c|c|c|}
\hline \multirow{2}{*}{$\begin{array}{l}\text { PIK3CA } \\
\text { Mutation } \\
\text { H1047X } \\
\end{array}$} & \multicolumn{3}{|c|}{$\begin{array}{l}\text { Patient Demographic } \\
\text { Source Gender Age }\end{array}$} & \multirow[t]{2}{*}{$\begin{array}{l}\text { WHO } \\
\text { Grade }\end{array}$} & \multirow[t]{2}{*}{\begin{tabular}{|l|} 
AJCC \\
Staging \\
\end{tabular}} & \multirow[t]{2}{*}{ Cause of Death } \\
\hline & & & & & & \\
\hline & Sigmoid & Female & 82 & Grade 2 & $\begin{array}{l}\text { T1N0M0 } \\
\text { Stage I }\end{array}$ & Cancer-related \\
\hline & $\begin{array}{l}\text { Hepatic } \\
\text { Flexure }\end{array}$ & Male & 76 & Grade 2 & $\begin{array}{l}\text { T3N0M0 } \\
\text { Stage II }\end{array}$ & Not cancer-related \\
\hline & Transverse & Male & 72 & Grade 2 & $\begin{array}{l}\text { T4N0M0 } \\
\text { Stage II }\end{array}$ & Not cancer-related \\
\hline & Transverse & Female & 76 & Grade 4 & $\begin{array}{l}\text { T3N0M0 } \\
\text { Stage II }\end{array}$ & Cancer-related \\
\hline & Cecum & Male & 62 & Grade 3 & $\begin{array}{l}\text { T3N0M0 } \\
\text { Stage II }\end{array}$ & Unknown \\
\hline & Colon & Female & 67 & Grade 2 & $\begin{array}{l}\text { T3N0M0 } \\
\text { Stage II } \\
\end{array}$ & Cancer-related \\
\hline & Right Colon & Female & 80 & Grade 2 & $\begin{array}{l}\text { T3N0Mx } \\
\text { Stage II }\end{array}$ & Unknown \\
\hline \multicolumn{7}{|l|}{ E545X } \\
\hline & Ascending & Male & 53 & Grade 2 & $\begin{array}{l}\text { T3N2M1 } \\
\text { Stage IV } \\
\end{array}$ & Cancer-related \\
\hline & Ascending & Female & 48 & Grade 2 & $\begin{array}{l}\text { T3N0M0 } \\
\text { Stage II }\end{array}$ & Not applicable \\
\hline & Ileocecal & Male & 55 & Grade 2 & $\begin{array}{l}\text { T3N1M0 } \\
\text { Stage III } \\
\end{array}$ & Unknown \\
\hline & Transverse & Male & 64 & Grade 2 & $\begin{array}{l}\text { T3N0M0 } \\
\text { Stage II }\end{array}$ & Cancer-related \\
\hline & Transverse & Female & 76 & Grade 4 & $\begin{array}{l}\text { T3N0M0 } \\
\text { Stage II }\end{array}$ & Cancer-related \\
\hline & Descending & Male & 78 & Grade 2 & $\begin{array}{l}\text { T4N2M0 } \\
\text { Stage III }\end{array}$ & Cancer-related \\
\hline & Ascending & Female & 79 & Grade 4 & $\begin{array}{l}\text { T3N0Mx } \\
\text { Stage II }\end{array}$ & $\begin{array}{l}\text { Not cancer- } \\
\text { related }\end{array}$ \\
\hline & Right Colon & Female & 80 & Grade 2 & $\begin{array}{l}\text { T3N0Mx } \\
\text { Stage II }\end{array}$ & Cancer-related \\
\hline G1049R & Sigmoid & Male & 69 & Grade 2 & N/A Bx & Cancer-related \\
\hline
\end{tabular}




\section{A.18 Correlation of PIK3CA Targeted Region Mutations with Clinicopathological Data for the Patient Cohort (continued).}

Table A.8. Correlation of PIK3CA Targeted Region Mutations with

Clinicopathological Data for the Patient Cohort (continued)

\begin{tabular}{|l|l|l|l|l|l|l|}
\hline \hline $\begin{array}{l}\text { PIK3CA } \\
\text { Mutation }\end{array}$ & $\begin{array}{l}\text { Patient Demographics } \\
\text { Source }\end{array}$ & $\begin{array}{l}\text { WHO } \\
\text { Histological } \\
\text { Grade }\end{array}$ & $\begin{array}{l}\text { AJCC } \\
\text { Staging }\end{array}$ & Cause of Death \\
\hline C420R & Cecum & Female & 81 & Grade 3 & $\begin{array}{l}\text { T4N2M0 } \\
\text { Stage III }\end{array}$ & Not cancer-related \\
\hline Q546X & Cecum & Male & 62 & Grade 4 & $\begin{array}{l}\text { T1No Mx } \\
\text { Stage I }\end{array}$ & Not applicable \\
\hline & Ascending & Male & 67 & Grade 2 & $\begin{array}{l}\text { T2N0M0 } \\
\text { Stage I }\end{array}$ & Unknown \\
\hline N345K & Descending & Female & 60 & Grade 4 & $\begin{array}{l}\text { T4N1M0 } \\
\text { Stage III }\end{array}$ & Cancer-related \\
\hline
\end{tabular}




\section{A.19 Diversity of Concomitant Mutations and Clinicopathological Features for the Patient Cohort.}

\section{Table A.9. Diversity of Concomitant Mutations and Clinicopathological}

Features for the Patient Cohort

Twenty-nine percent of the patients in our cohort had malignancies in which multiple mutations were identified. Malignancies arising in the ascending colon demonstrated the greatest mutational diversity and the frequency of concomitant mutations gradually decreased from the transverse colon to the rectum.

\begin{tabular}{|c|c|c|c|c|c|c|}
\hline \multicolumn{3}{|c|}{ Patient Demographics } & \multirow{2}{*}{$\begin{array}{c}\text { WHO } \\
\text { Histologic } \\
\text { Grade }\end{array}$} & \multirow{2}{*}{$\begin{array}{c}\text { AJCC } \\
\text { Staging }\end{array}$} & \multirow{2}{*}{$\begin{array}{c}\text { Cause } \\
\text { of } \\
\text { Death }\end{array}$} & \multirow{2}{*}{$\begin{array}{c}\text { Characterization of } \\
\text { Mutations: }\end{array}$} \\
\hline Gender & Age & Source & & & & \\
\hline Female & 81 & Cecum & Grade 3 & $\begin{array}{l}\text { T4N2M0 } \\
\text { Stage III }\end{array}$ & $\begin{array}{c}\text { Not } \\
\text { cancer- } \\
\text { related }\end{array}$ & $\begin{array}{c}\text { MMR Status: } \\
\text { deficient, loss of } \\
\text { MLH1/PMS2 (bx, } \\
\text { resection + nodes) } \\
\text { PDL-1 expression: } \\
\text { 30\% (bx \& nodes), } \\
\text { 75\% exp in resection. } \\
\text { BRAF V600E/E2/D } \\
\text { Positive via IHC and } \\
\text { PCR (bx, resection, } \\
\text { nodes) } \\
\text { PIK3CA C420R (bx, } \\
\text { resection + nodes). }\end{array}$ \\
\hline Male & 53 & Ascending & Grade 2 & $\begin{array}{l}\text { T3N2M1 } \\
\text { Stage IV }\end{array}$ & $\begin{array}{l}\text { Cancer- } \\
\text { related }\end{array}$ & $\begin{array}{l}\text { Resection \& nodes: } \\
\text { Positive for KRAS } \\
\text { A146x mutation } \\
\text { Nodes: positive for } \\
\text { PIK3CA E545x } \\
\text { mutation. }\end{array}$ \\
\hline
\end{tabular}




\section{A.20 Diversity of Concomitant Mutations and Clinicopathological Features (continued).}

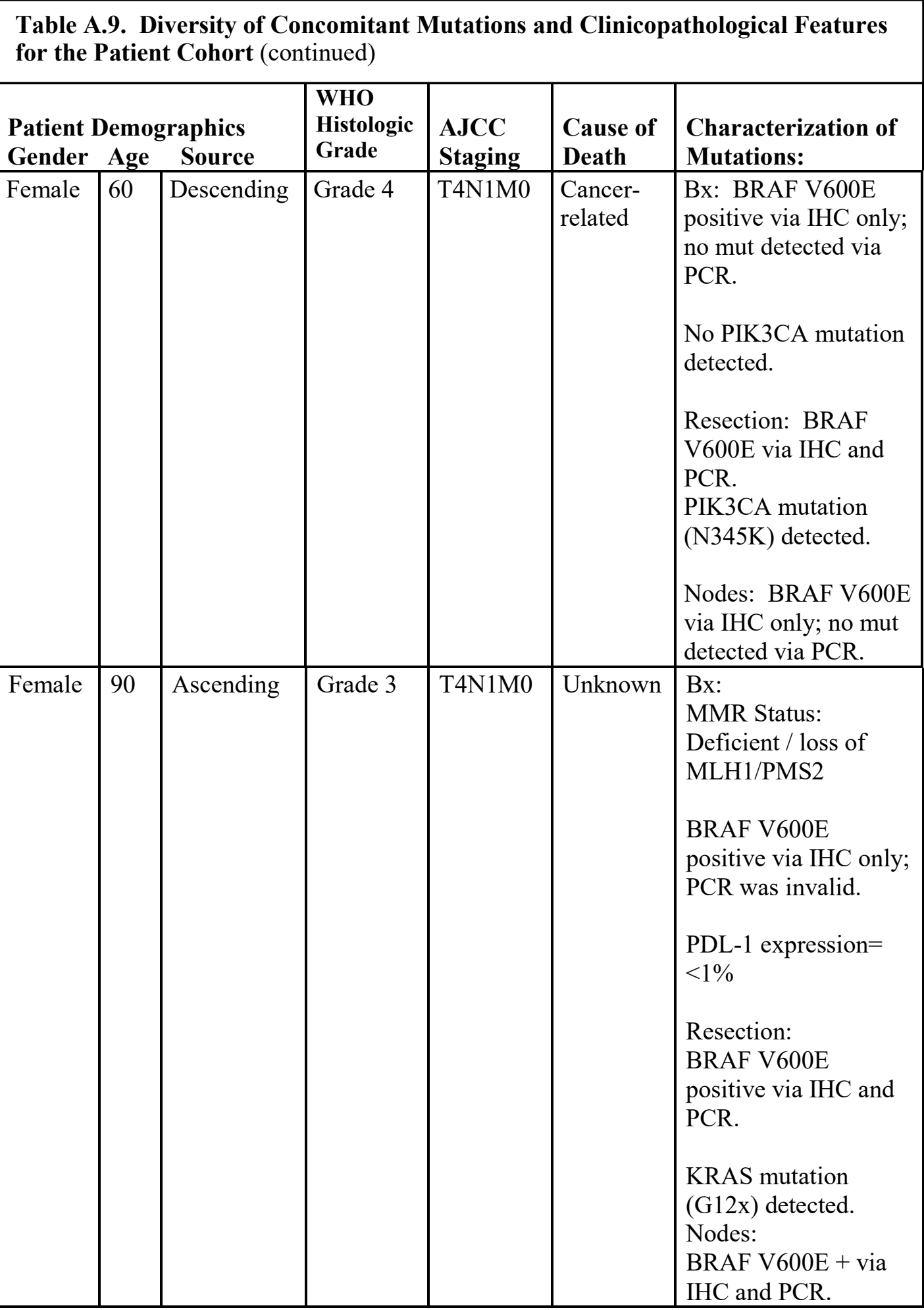




\section{A.21 Diversity of Concomitant Mutations and Clinicopathological Features (continued).}

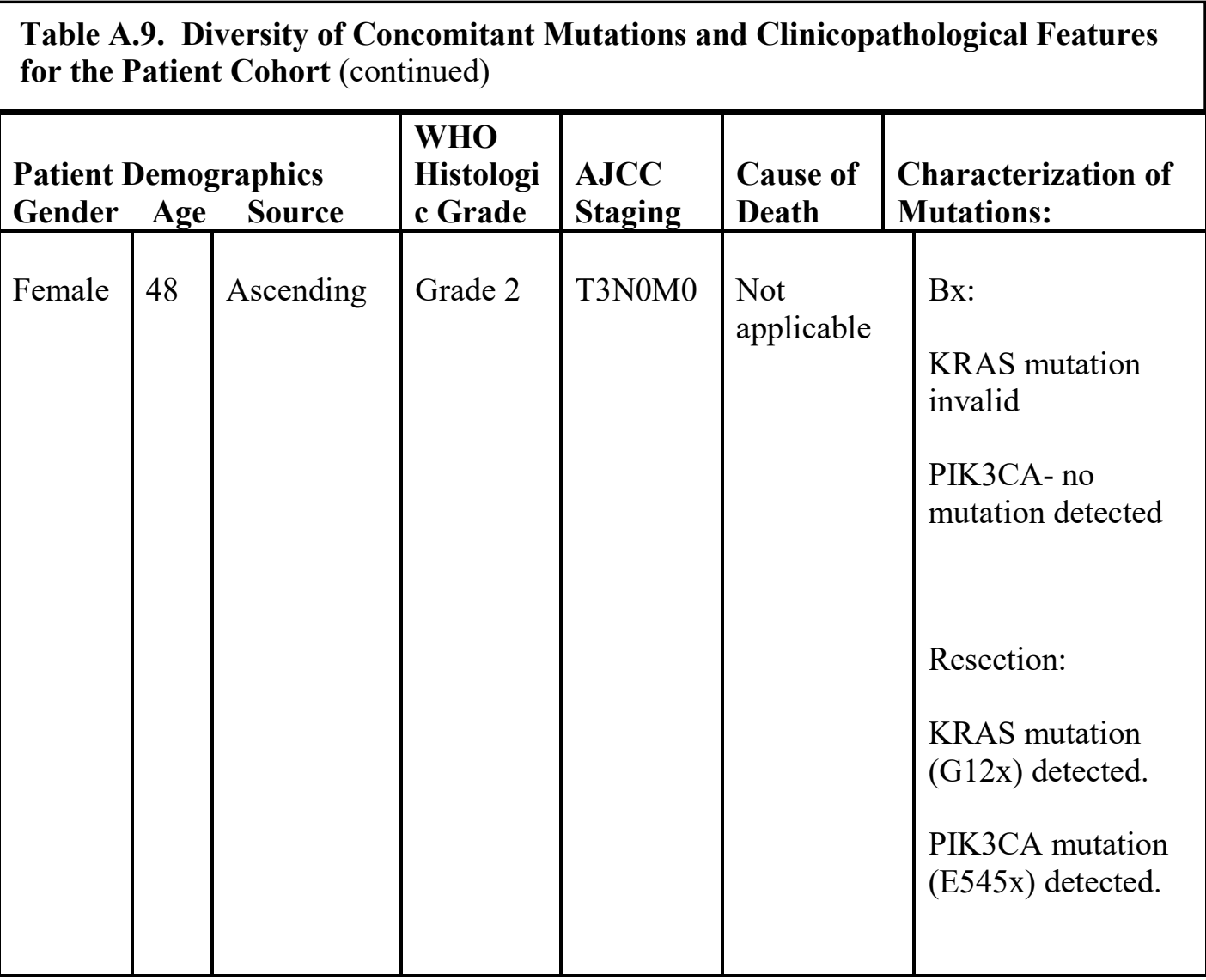




\section{A.22 Diversity of Concomitant Mutations and Clinicopathological Features (continued).}

Table A.9. Diversity of Concomitant Mutations and Clinicopathological Features for the Patient Cohort (continued)

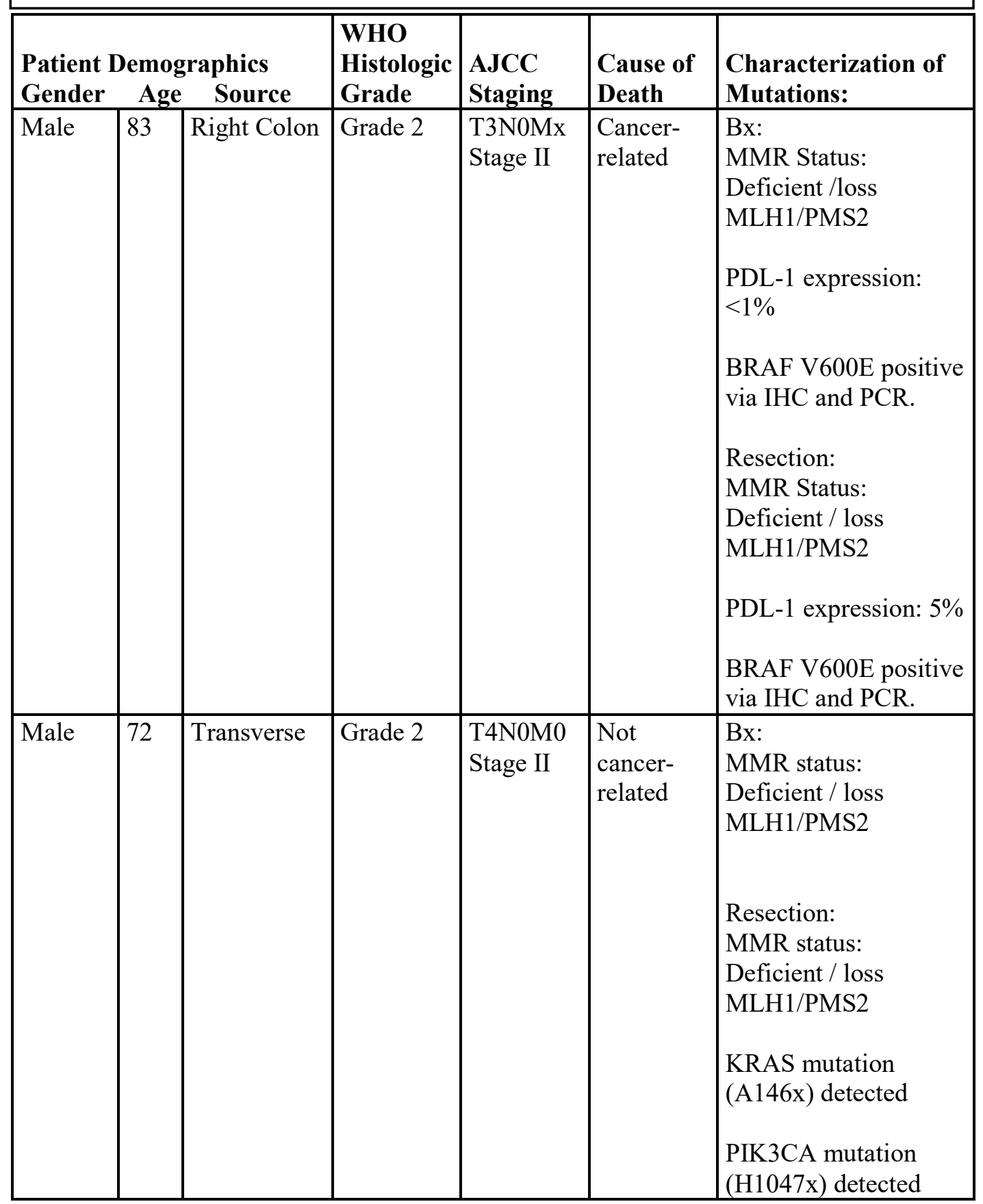




\section{A.23 Diversity of Concomitant Mutations and Clinicopathological Features (continued).}

\begin{tabular}{|c|c|c|c|c|c|c|}
\hline \multicolumn{3}{|c|}{$\begin{array}{l}\text { Patient Demographics } \\
\text { Gender Age Source }\end{array}$} & \multirow{2}{*}{$\begin{array}{l}\text { WHO } \\
\text { Grade } \\
\text { Grade } 1 \\
\text { arising in } \\
\text { tubular } \\
\text { adenoma }\end{array}$} & \multirow{2}{*}{$\begin{array}{c}\text { AJCC } \\
\text { Staging } \\
\text { T3N0M0 }\end{array}$} & \multirow{2}{*}{\begin{tabular}{|l|}
$\begin{array}{c}\text { Cause of } \\
\text { Death }\end{array}$ \\
Unknown
\end{tabular}} & \multirow{2}{*}{$\begin{array}{l}\begin{array}{l}\text { Characterization } \\
\text { of Mutations: }\end{array} \\
\text { Resection: } \\
\text { PDL-1 expression in } \\
\text { TC: } 3 \% \text { expression } \\
\\
\text { BRAF V600E positive } \\
\text { via IHC and PCR. } \\
\end{array}$} \\
\hline Male & 64 & $\begin{array}{l}\text { Splenic } \\
\text { Flexure }\end{array}$ & & & & \\
\hline Male & 68 & Sigmoid & Grade 3 & T3N0M0 & $\begin{array}{l}\text { Cancer- } \\
\text { related }\end{array}$ & $\begin{array}{l}\text { Resection: } \\
\text { PDL-1 expression in } \\
\text { TC: } 5 \% \text { expression } \\
\text { KRAS mutation } \\
(\text { G12x) detected }\end{array}$ \\
\hline Female & 87 & Ascending & Grade 2 & T3N0M0 & $\begin{array}{l}\text { Cancer- } \\
\text { related }\end{array}$ & $\begin{array}{l}\text { Resection: } \\
\text { MMR Status: } \\
\text { Deficient / loss } \\
\text { MLH1/PMS2 } \\
\text { BRAF V600E positive } \\
\text { via IHC and PCR. } \\
\end{array}$ \\
\hline Female & 83 & Ascending & Grade 2 & T2N0M) & $\begin{array}{l}\text { Not } \\
\text { cancer- } \\
\text { related }\end{array}$ & $\begin{array}{l}\text { Resection: } \\
\text { PDL-1 expression } \\
\text { inTC: }<1 \% \text { expression } \\
\text { KRAS mutation } \\
(\mathrm{G} 12 \mathrm{x}) \text { detected } \\
\end{array}$ \\
\hline Female & 86 & Ascending & Grade 2 & T1N0M0 & $\begin{array}{l}\text { Cancer- } \\
\text { related }\end{array}$ & $\begin{array}{l}\text { Resection: } \\
\text { KRAS co-mutations } \\
(\mathrm{G} 12 \mathrm{x} \text { and } \mathrm{G} 13 \mathrm{x})\end{array}$ \\
\hline Male & 67 & Ascending & Grade 2 & T2N0M0 & Unknown & $\begin{array}{l}\text { Resection: } \\
\text { PDL-1 expression in } \\
\text { TC: }<1 \% \text { expression } \\
\text { KRAS mutation } \\
\text { (G12x) detected } \\
\text { PIK3CA mutation } \\
\text { (Q546x) detected }\end{array}$ \\
\hline
\end{tabular}




\section{A.24 Diversity of Concomitant Mutations and Clinicopathological Features (continued).}

\begin{tabular}{|c|c|c|c|c|c|c|}
\hline \multicolumn{2}{|c|}{ Patient Demographics } & $\begin{array}{r}\text { graphics } \\
\text { Source } \\
\end{array}$ & \multirow{2}{*}{\begin{tabular}{|l|} 
WHO \\
Histologic \\
Grade \\
Grade 2 \\
\end{tabular}} & \multirow{2}{*}{\begin{tabular}{|l|}
$\begin{array}{c}\text { AJCC } \\
\text { Staging }\end{array}$ \\
T2N0M0 \\
\end{tabular}} & \multirow{2}{*}{\begin{tabular}{|l|}
$\begin{array}{l}\text { Cause of } \\
\text { Death }\end{array}$ \\
$\begin{array}{l}\text { Cancer- } \\
\text { related }\end{array}$ \\
\end{tabular}} & \multirow{2}{*}{\begin{tabular}{|l|}
$\begin{array}{l}\text { Characterization of } \\
\text { Mutations: }\end{array}$ \\
Resection: \\
MMR Status: \\
Deficient / loss \\
MLH1/PMS2 \\
PDL-1 expression in \\
TC: <1\% expression \\
BRAF V600E positive \\
via IHC and PCR.
\end{tabular}} \\
\hline Female & 69 & Descending & & & & \\
\hline Female & 76 & Transverse & Grade 4 & T3N0M0 & $\begin{array}{l}\text { Cancer- } \\
\text { related }\end{array}$ & $\begin{array}{l}\text { Resection: } \\
\text { PDL-1 expression in } \\
\text { TC: }<1 \% \text { expression } \\
\text { KRAS mutation } \\
\text { (G12x) detected } \\
\text { PIK3CA co-mutations } \\
\text { (H1047x \& E545x) } \\
\text { detected }\end{array}$ \\
\hline Male & 64 & Transverse & Grade 2 & T3N0M0 & $\begin{array}{l}\text { Cancer- } \\
\text { related }\end{array}$ & $\begin{array}{l}\text { Resection: } \\
\text { BRAF V600E positive } \\
\text { via IHC and PCR } \\
\text { PIK3CA mutations } \\
\text { (E545x) detected }\end{array}$ \\
\hline Male & 66 & Cecum & Grade 2 & T3N0M0 & Unknown & $\begin{array}{l}\text { Resection: } \\
\text { MMR Status: } \\
\text { Deficient / loss } \\
\text { MLH1/PMS2 } \\
\text { BRAF V600E positive } \\
\text { via IHC and PCR. }\end{array}$ \\
\hline
\end{tabular}




\section{A.25 Diversity of Concomitant Mutations and Clinicopathological Features (continued).}

\begin{tabular}{|c|c|c|c|c|c|c|}
\hline \begin{tabular}{|l|} 
Patient \\
Gender \\
\end{tabular} & Demog & $\begin{array}{r}\text { graphics } \\
\text { Source } \\
\end{array}$ & \begin{tabular}{|l} 
WHO \\
Histologic \\
Grade \\
\end{tabular} & \begin{tabular}{|c|} 
AJCC \\
Staging
\end{tabular} & \begin{tabular}{|l} 
Cause of \\
Death
\end{tabular} & $\begin{array}{l}\text { Characterization of } \\
\text { Mutations: }\end{array}$ \\
\hline Male & 64 & Sigmoid & Grade 2 & T3N0M0 & Unknown & $\begin{array}{l}\text { Resection: } \\
\text { MMR Status: } \\
\text { Deficient / loss of } \\
\text { MLH1/PMS2, } \\
\text { MSH2/MSH6 } \\
\text { BRAF V600E positive } \\
\text { via IHC and PCR. }\end{array}$ \\
\hline Female & 51 & Cecum & Grade 2 & T2N0M0 & $\begin{array}{l}\text { Not } \\
\text { applicable }\end{array}$ & $\begin{array}{l}\text { Resection: } \\
\text { PDL-1 expression in } \\
\text { TC }=1 \% \text { expression } \\
\text { KRAS mutation } \\
\text { (G12x) detected }\end{array}$ \\
\hline Male & 62 & Right colon & $\begin{array}{l}\text { Grade } 2 \\
\text { (Arising } \\
\text { in TA) }\end{array}$ & T3N0M0 & $\begin{array}{l}\text { Not } \\
\text { applicable }\end{array}$ & $\begin{array}{l}\text { Resection: } \\
\text { MMR Status: } \\
\text { Deficient / loss } \\
\text { MLH1/PMS2) } \\
\text { PDL-1 expression: } \\
<1 \% \text {; lots in IC in } \\
\text { stroma }\end{array}$ \\
\hline Male & 62 & Cecum & Grade 3 & T3N0M0 & Unknown & $\begin{array}{l}\text { Resection: } \\
\text { KRAS mutation } \\
\text { (G12x) detected } \\
\text { PIK3CA mutation } \\
\text { (H1047x) detected }\end{array}$ \\
\hline
\end{tabular}




\section{A.26 Diversity of Concomitant Mutations and Clinicopathological Features (continued).}

\footnotetext{
Table A.9. Diversity of Concomitant Mutations and Clinicopathological Features for the Patient Cohort (continued)
}

\begin{tabular}{|c|c|c|c|c|c|c|}
\hline \multicolumn{3}{|c|}{ Patient Demographics } & \multirow{2}{*}{\begin{tabular}{|l|}
$\begin{array}{l}\text { WHO } \\
\text { Grade }\end{array}$ \\
Grade 2 \\
\end{tabular}} & \multirow{2}{*}{$\begin{array}{c}\text { AJCC } \\
\text { Staging } \\
\text { T4N0M0 }\end{array}$} & \multirow{2}{*}{$\begin{array}{l}\begin{array}{l}\text { Cause of } \\
\text { Death }\end{array} \\
\begin{array}{l}\text { Cancer- } \\
\text { related }\end{array}\end{array}$} & \multirow{2}{*}{$\begin{array}{l}\begin{array}{l}\text { Characterization of } \\
\text { Mutations: }\end{array} \\
\text { Resection: } \\
\text { MMR Status: } \\
\text { Deficient / loss } \\
\text { MSH2); lots in IC } \\
\text { KRAS mutation } \\
\text { (G13x) detected. }\end{array}$} \\
\hline Female & 67 & $\begin{array}{l}\text { Splenic } \\
\text { flexure }\end{array}$ & & & & \\
\hline Male & 88 & Cecum & Grade 2 & T2N0M0 & $\begin{array}{l}\text { Cancer- } \\
\text { related }\end{array}$ & $\begin{array}{l}\text { Resection: } \\
\text { MMR Status: } \\
\text { Deficient / loss MSH6 } \\
\text { KRAS mutation } \\
\text { (G12x) detected. }\end{array}$ \\
\hline Female & 67 & Colon, NOS & Grade 2 & T3N0M0 & $\begin{array}{l}\text { Cancer- } \\
\text { related }\end{array}$ & $\begin{array}{l}\text { Resection: } \\
\text { MMR Status: } \\
\text { Deficient / loss } \\
\text { MLH1/PMS2 } \\
\\
\text { PIK3CA mutation } \\
\text { (H1047x) detected } \\
\end{array}$ \\
\hline Male & 60 & Appendix & Grade 2 & T1N0M0 & $\begin{array}{l}\text { Not cancer- } \\
\text { related }\end{array}$ & $\begin{array}{l}\text { Resection: } \\
\text { PDL-1 expression in } \\
\text { TC: } 10-29 \% \\
\text { expression } \\
\\
\text { KRAS mutation } \\
\text { (G12x) detected } \\
\end{array}$ \\
\hline Female & 83 & Transverse & Grade 3 & T4N0M0 & $\begin{array}{l}\text { Not cancer- } \\
\text { related }\end{array}$ & $\begin{array}{l}\text { Resection: } \\
\text { MMR Status: } \\
\text { Deficient / loss } \\
\text { MLH1/PMS2 } \\
\text { PDL-1 expression in } \\
\text { TC: }<1 \% \text { expression } \\
\text { BRAF V600E } \\
\text { positive via IHC and } \\
\text { PCR. }\end{array}$ \\
\hline
\end{tabular}




\section{A.27 Diversity of Concomitant Mutations and Clinicopathological Features (continued)}

\begin{tabular}{|c|c|c|c|c|c|c|}
\hline Patient & Demo & graphics & WHO & AJCC & Cause of & Characterization of \\
\hline Gender & Ag & Source & Grade & & & \\
\hline Female & 83 & Cecum & Grade 3 & T3N0M0 & $\begin{array}{l}\text { Cancer- } \\
\text { related }\end{array}$ & $\begin{array}{l}\text { Resection: } \\
\text { MMR Status: } \\
\text { Deficient / loss } \\
\text { MLH1/PMS2 } \\
\text { PDL-1 expression in } \\
\text { TC: } 1-9 \% \text { expression } \\
\text { BRAF V600E } \\
\text { positive via IHC and } \\
\text { PCR. }\end{array}$ \\
\hline Female & 87 & $\begin{array}{l}\text { Splenic } \\
\text { Flexure }\end{array}$ & Grade 2 & T3N0Mx & $\begin{array}{l}\text { Not cancer- } \\
\text { related }\end{array}$ & $\begin{array}{l}\text { Resection: } \\
\text { PDL-1 expression in } \\
\text { TC: }<1 \% \text { expression } \\
\text { BRAF V600E } \\
\text { positive via IHC and } \\
\text { PCR. }\end{array}$ \\
\hline
\end{tabular}




\section{A.28 Diversity of Concomitant Mutations and Clinicopathological Features (continued).}

\begin{tabular}{|c|c|c|c|c|c|c|}
\hline \multicolumn{3}{|c|}{$\begin{array}{l}\text { Patient Demographics } \\
\text { Gender Age Source }\end{array}$} & $\begin{array}{l}\text { WHO } \\
\text { Grade }\end{array}$ & $\begin{array}{c}\text { AJCC } \\
\text { Staging }\end{array}$ & $\begin{array}{l}\text { Cause of } \\
\text { Death }\end{array}$ & $\begin{array}{l}\text { Characterization of } \\
\text { Mutations: }\end{array}$ \\
\hline Female & 80 & Right Colon & $\begin{array}{l}\text { synch } \\
\text { Block \#2: } \\
\text { grade } 2 \\
\text { Block \#6: } \\
\text { grade 1 } \\
\end{array}$ & $\begin{array}{l}\text { T3N0Mx } \\
\text { T1N0Mx }\end{array}$ & $\begin{array}{l}\text { Cancer- } \\
\text { related }\end{array}$ & $\begin{array}{l}\text { Block \#2 } \\
\text { MMR status: Loss } \\
\text { MLH1/PMS2 } \\
\text { PDL-1 expression in TC: } \\
\text { 10-29\% expression } \\
\text { BRAF V600E positive via } \\
\text { IHC and PCR } \\
\text { PIK3CA co-mutations } \\
\text { (H1047x \& E545x) } \\
\text { detected } \\
\text { Block \#6 } \\
\text { MMR status: Loss } \\
\text { MLH1/PMS2 } \\
\text { PDL-1 expression in TC: } \\
\text { 1-9\% expression } \\
\text { BRAF V600E positive via } \\
\text { IHC and PCR } \\
\text { Biopsy } \\
\text { MMR status: Loss } \\
\text { MLH1/PMS2) } \\
\text { PDL-1 expression in TC= } \\
\text { 1-9\% expression } \\
\text { BRAF V600E positive via } \\
\text { IHC } \\
\text { Resection: } \\
\text { MMR status: Deficient / } \\
\text { loss MLH1/PMS2 } \\
\text { PDL-1 expression in TC: } \\
\text { 10-29\% expression } \\
\text { BRAF V600E positive via } \\
\text { IHC and PCR. }\end{array}$ \\
\hline
\end{tabular}




\section{A.29 Diversity of Concomitant Mutations and Clinicopathological Features (continued).}

Table A.9. Diversity of Concomitant Mutations and Clinicopathological Features for the Patient Cohort (continued)

\begin{tabular}{|c|c|c|c|c|c|c|}
\hline \multicolumn{3}{|c|}{$\begin{array}{l}\text { Patient Demographics } \\
\text { Gender Age Source }\end{array}$} & \multirow{2}{*}{\begin{tabular}{|l|} 
WHO \\
Grade
\end{tabular}} & \multirow{2}{*}{$\begin{array}{c}\begin{array}{c}\text { AJCC } \\
\text { Staging }\end{array} \\
\text { T3N0M0 }\end{array}$} & \multirow{2}{*}{\begin{tabular}{|l|}
$\begin{array}{l}\text { Cause of } \\
\text { Death }\end{array}$ \\
$\begin{array}{l}\text { Not } \\
\text { applicable }\end{array}$
\end{tabular}} & \multirow{2}{*}{$\begin{array}{l}\begin{array}{l}\text { Characterization of } \\
\text { Mutations: }\end{array} \\
\text { Resection: } \\
\text { MMR status: Deficient } \\
\text { / loss PMS2 } \\
\text { NRAS mutation (Q61x) } \\
\text { detected }\end{array}$} \\
\hline Male & 53 & Colon, NOS & & & & \\
\hline Female & 70 & $\begin{array}{l}\text { Sigmoid } \\
\text { and } \\
\text { Rectum }\end{array}$ & $\begin{array}{l}\text { All were } \\
\text { grade } 2\end{array}$ & $\begin{array}{l}\text { All } \\
\text { T3N2Mx }\end{array}$ & $\begin{array}{l}\text { Cancer- } \\
\text { related }\end{array}$ & $\begin{array}{l}\text { Resection: } \\
\text { PDL-1 expression: 1- } \\
\text { 9\% expression } \\
\text { KRAS mutation (G13x) } \\
\text { detected. } \\
\text { Nodes: } \\
\text { KRAS mutation (G13x) } \\
\text { detected. } \\
\text { Sacrum: } \\
\text { KRAS mutation (G13x) } \\
\text { detected. } \\
\text { Rectum: } \\
\text { KRAS mutation (G13x) } \\
\text { detected }\end{array}$ \\
\hline Female & 70 & $\begin{array}{l}\text { Synchronous } \\
\text { cancers } \\
\text { Ascending } \\
\& \\
\text { Transverse }\end{array}$ & $\begin{array}{l}\text { Block \#3: } \\
\text { Ascending } \\
\text { Grade } 3 \\
\text { Block \#7: } \\
\text { Transverse } \\
\text { Grade } 2\end{array}$ & $\begin{array}{l}\text { T3N0Mx } \\
\text { T3N0M0 }\end{array}$ & $\begin{array}{l}\text { Not } \\
\text { applicable }\end{array}$ & $\begin{array}{l}\text { Both blocks: } \\
\text { MMR Status: Deficient } \\
\text { / loss MLH1/PMS2 } \\
\text { BRAF V600E positive } \\
\text { via IHC }\end{array}$ \\
\hline
\end{tabular}




\section{A.30 Diversity of Concomitant Mutations and Clinicopathological Features (continued).}

Table A.9. Diversity of Concomitant Mutations and Clinicopathological Features for the Patient Cohort (continued)

\begin{tabular}{|c|c|c|c|c|c|c|}
\hline \multicolumn{3}{|c|}{ Patient Demographics } & \begin{tabular}{l|} 
WHO \\
Histologic \\
Grade
\end{tabular} & $\begin{array}{l}\text { AJCC } \\
\text { Staging }\end{array}$ & $\begin{array}{l}\text { Cause of } \\
\text { Death }\end{array}$ & $\begin{array}{l}\text { Characterization of } \\
\text { Mutations: }\end{array}$ \\
\hline Female & 79 & $\begin{array}{l}\text { Synchronous } \\
\text { cancers } \\
\text { Ascending }\end{array}$ & $\begin{array}{l}\text { Block B6: } \\
\text { Ascending } \\
\text { (1 cm from } \\
\text { ileocecal } \\
\text { valve) } \\
\text { Grade } 4 \\
\\
\text { Block } \\
\text { B10: } \\
\text { Ascending } \\
\text { (distal to } \\
1^{0} \text { mass) } \\
\text { Grade } 4\end{array}$ & $\begin{array}{l}\text { T3N0Mx } \\
\text { T3N0Mx }\end{array}$ & $\begin{array}{l}\text { Not } \\
\text { cancer- } \\
\text { related }\end{array}$ & $\begin{array}{l}\text { Block B6: } \\
\text { MSI-High (loss } \\
\text { MLH1/PMS2) } \\
\text { PIK3CA mutation } \\
\text { (E545x) detected. } \\
\\
\text { Block B10: } \\
\text { MSI-low (loss MLH1) } \\
\text { PIK3CA mutation } \\
\text { (E545x) detected. } \\
\end{array}$ \\
\hline
\end{tabular}




\section{A.31 Mismatch Repair IHC Staining Depicting Intact MMR Proteins in Colon Resection.}

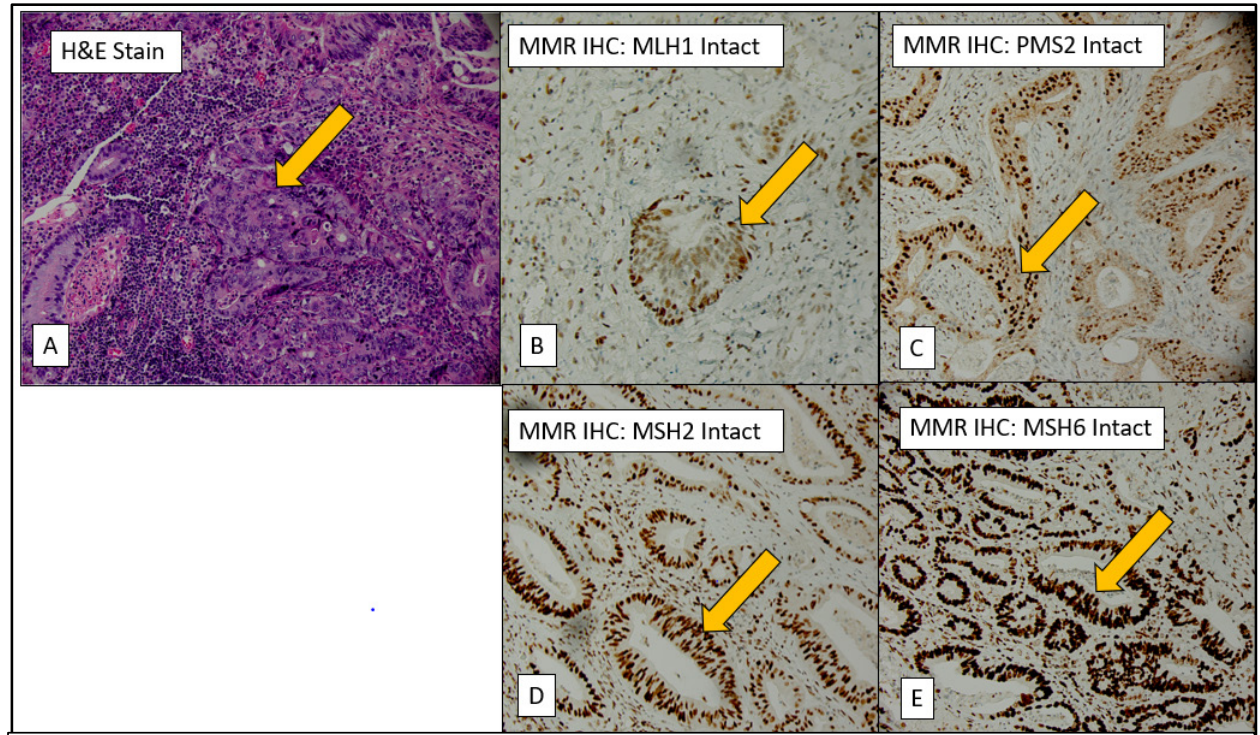

Figure A.7. Mismatch Repair IHC Staining Depicting Intact MMR

Proteins in Colon Resection. a) Hematoxylin \& Eosin stain (arrow denotes) malignant cells, b) MLH1 shows positive nuclear staining in tumor cells, c) PMS2 demonstrates positive nuclear staining in the tumor cells, d) MSH2 demonstrates positive nuclear staining in the tumor cells, e) MSH6 demonstrates positive nuclear staining in tumor cells. All images were taken at 40x magnification. 


\section{A.32 Mismatch Repair IHC Staining Depicting Intact MMR Repair Proteins in mCRC in Lymph Node.}

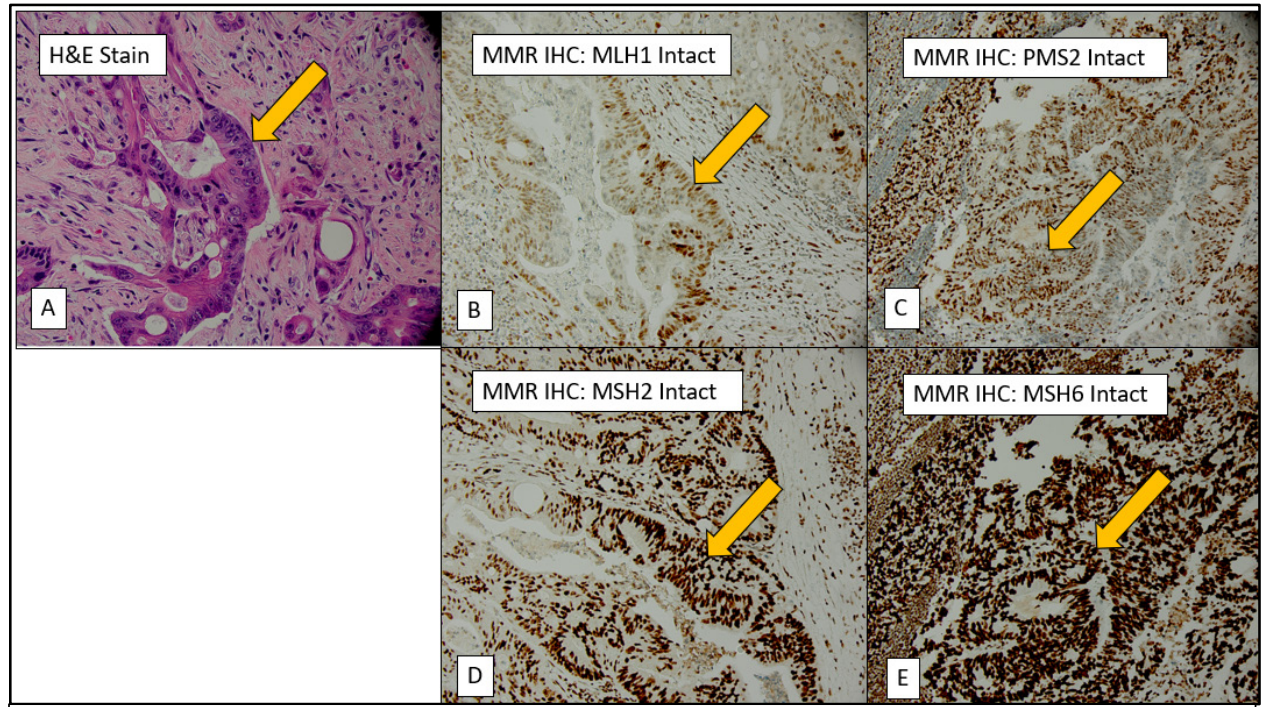

Figure A.8. Mismatch Repair IHC Staining Depicting Intact MMR

Proteins in mCRC in Lymph Node. a) Hematoxylin \& Eosin stain (arrow denotes) malignant cells, b) MLH1 shows positive nuclear staining in tumor cells, c) PMS2 demonstrates positive nuclear staining in the tumor cells, d) MSH2 demonstrates positive nuclear staining in the tumor cells, e) MSH6 demonstrates positive nuclear staining in tumor cells. All images were taken at $40 x$ magnification. 


\section{A.33 Mismatch Repair IHC Staining Depicting Deficient MMR Repair Proteins in mCRC in Colon Resection.}

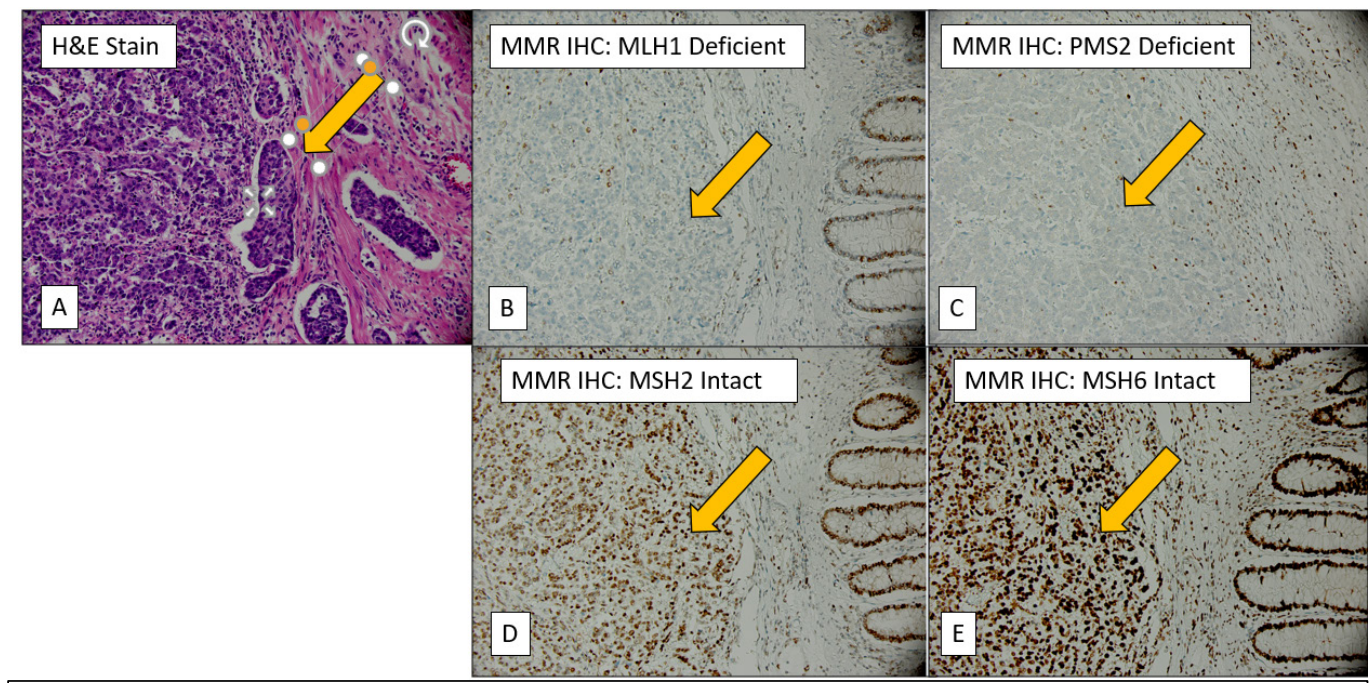

Figure A.9. Mismatch Repair IHC Staining Depicting Deficient MMR Proteins in Colon Resection. a) Hematoxylin \& Eosin stain (arrow denotes) malignant cells, b) MLH1 shows absence of nuclear staining in tumor cells but is present in adjacent normal colonic epithelium which serves as an internal control c) PMS2 demonstrates absence nuclear staining in the tumor cells, d) MSH2 demonstrates positive nuclear staining in the tumor cells, e) MSH6 demonstrates positive nuclear staining in tumor cells. All images were taken at 40x magnification. 


\section{A.34 Mismatch Repair IHC Staining Depicting Deficient MMR Protein in mCRC in Lymph Node.}

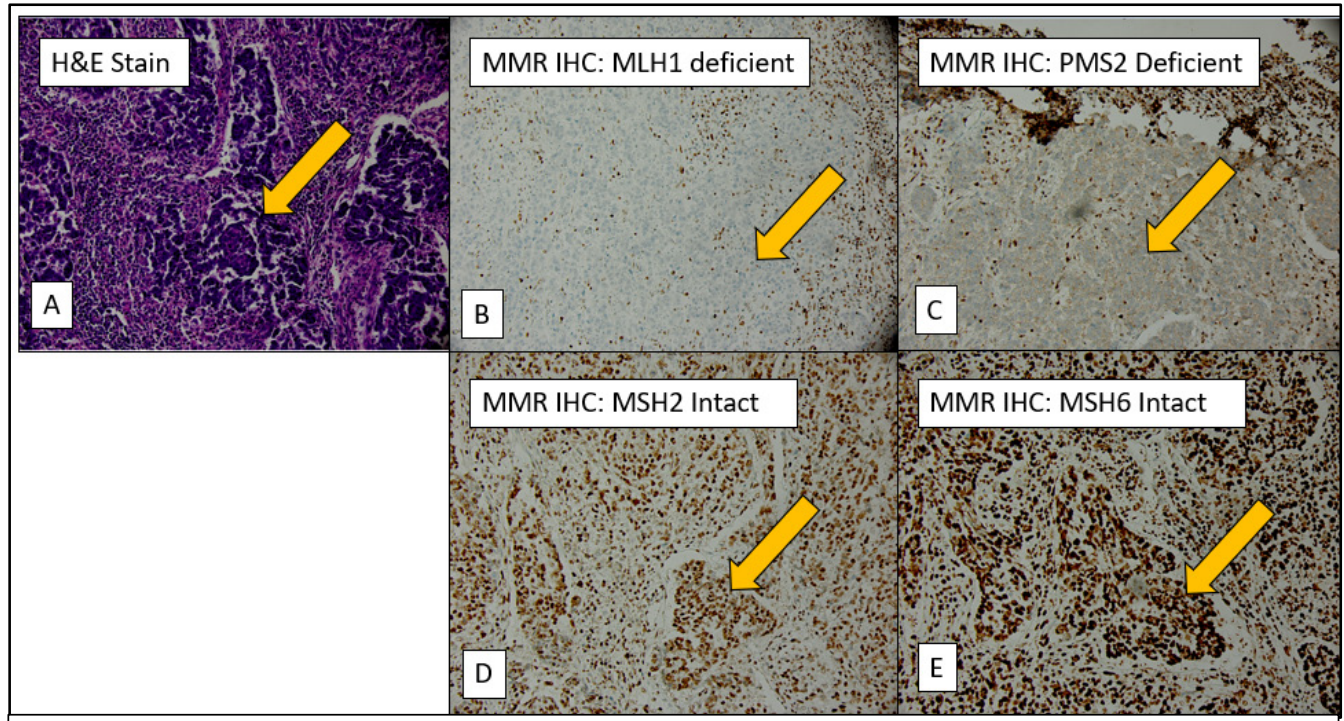

Figure A.10. Mismatch Repair IHC Staining Depicting Deficient MMR

Proteins in mCRC in Lymph Node. a) Hematoxylin \& Eosin stain (arrow denotes) malignant cells, b) MLH1 shows absence of nuclear staining in tumor cells c) PMS2 demonstrates absence nuclear staining in the tumor cells, d) MSH2 demonstrates positive nuclear staining in the tumor cells, e) MSH6 demonstrates positive nuclear staining in tumor cells. All images were taken at $40 \mathrm{x}$ magnification. 


\section{A.35 Characterization of Malignancies with Intact DNA Mismatch Repair Proteins.}

\begin{tabular}{|c|c|c|c|c|c|}
\hline \multicolumn{6}{|c|}{$\begin{array}{l}\text { Table A.10. Characterization of Malignancies with Intact DNA } \\
\text { Mismatch Repair Proteins. }\end{array}$} \\
\hline \multicolumn{3}{|c|}{ Patient Demographics } & \multirow{2}{*}{$\begin{array}{c}\text { WHO } \\
\text { Histologic } \\
\text { Grade }\end{array}$} & \multirow{2}{*}{$\begin{array}{l}\text { AJCC } \\
\text { Staging }\end{array}$} & \multirow{2}{*}{$\begin{array}{l}\text { Cause of } \\
\text { Death }\end{array}$} \\
\hline Source & Gender & Age & & & \\
\hline Rectum & Male & 46 & Grade 3 & $\begin{array}{l}\text { T2 N2 } \\
\text { M0 } \\
\text { Stage III }\end{array}$ & Unknown \\
\hline Sigmoid & Male & 69 & $\begin{array}{l}\text { Bx: } \\
\text { Grade } 2 \\
\text { Resection: } \\
\text { Grade } 3\end{array}$ & $\begin{array}{l}\text { T3N1M3 } \\
\text { Stage IV }\end{array}$ & Unknown \\
\hline Cecum & Male & 70 & $\begin{array}{l}\text { Bx: } \\
\text { Not spec } \\
\text { Resection: } \\
\text { Grade } 2\end{array}$ & $\begin{array}{l}\text { T3N2M1 } \\
\text { Stage IV }\end{array}$ & Unknown \\
\hline Rectum & Male & 35 & Grade 2 & $\begin{array}{l}\text { T3N1M0 } \\
\text { Stage III }\end{array}$ & Unknown \\
\hline Sigmoid & Male & 61 & Grade 2 & $\begin{array}{l}\text { T3N2M0 } \\
\text { Stage III }\end{array}$ & $\begin{array}{l}\text { Not cancer- } \\
\text { related }\end{array}$ \\
\hline Sigmoid & Male & 49 & Grade 2 & $\begin{array}{l}\text { T3N1M0 } \\
\text { Stage III }\end{array}$ & Unknown \\
\hline Hepatic flexure & Female & 65 & $\begin{array}{l}\text { Bx: } \\
\text { Grade } 2 \\
\text { Resection: } \\
\text { Grade 2 }\end{array}$ & $\begin{array}{l}\text { T3N1M0 } \\
\text { Stage III }\end{array}$ & Unknown \\
\hline Ascending & Male & 50 & Grade 2 & $\begin{array}{l}\text { T2N1M0 } \\
\text { Stage III }\end{array}$ & $\begin{array}{l}\text { Not cancer- } \\
\text { related }\end{array}$ \\
\hline Transverse & Female & 66 & Grade 2 & $\begin{array}{l}\text { T3N1M0 } \\
\text { Stage III }\end{array}$ & Cancer-related \\
\hline Hepatic flexure & Female & 63 & Grade 2 & $\begin{array}{l}\text { T4N1M0 } \\
\text { Stage III }\end{array}$ & Not applicable \\
\hline Rectum & Male & 78 & Grade 2 & $\begin{array}{l}\text { T2N1Mx } \\
\text { Stage III }\end{array}$ & Unknown \\
\hline
\end{tabular}




\section{A.36 Characterization of Malignancies with Intact DNA Mismatch Repair Proteins (continued).}

\begin{tabular}{|c|c|c|c|c|c|}
\hline \multicolumn{6}{|c|}{$\begin{array}{l}\text { Table A.10. Characterization of Malignancies with Intact DNA } \\
\text { Mismatch Repair Proteins (continued) }\end{array}$} \\
\hline \multicolumn{3}{|c|}{ Patient Demographics } & \multirow{2}{*}{$\begin{array}{c}\text { WHO } \\
\text { Histologic } \\
\text { Grade } \\
\end{array}$} & \multirow{2}{*}{$\begin{array}{c}\text { AJCC } \\
\text { Staging }\end{array}$} & \multirow{2}{*}{$\begin{array}{c}\text { Cause of } \\
\text { Death }\end{array}$} \\
\hline Source & Gender & Age & & & \\
\hline Rectum & Female & 65 & Grade 2 & $\begin{array}{l}\text { T3N1M0 } \\
\text { Stage III }\end{array}$ & Cancer-related \\
\hline Sigmoid & Female & 45 & Grade 2 & $\begin{array}{l}\text { T3N1M0 } \\
\text { Stage III }\end{array}$ & Unknown \\
\hline Cecum & Female & 71 & Grade 3 & $\begin{array}{l}\text { T3N1M0 } \\
\text { Stage III }\end{array}$ & Cancer-related \\
\hline Ascending & Male & 53 & Grade 2 & $\begin{array}{l}\text { T2N2M1 } \\
\text { Stage IV }\end{array}$ & Cancer-related \\
\hline Rectum & Male & 78 & Grade 3 & $\begin{array}{l}\text { T3N2M0 } \\
\text { Stage III }\end{array}$ & Cancer-related \\
\hline $\begin{array}{l}\text { Overlapping } \\
\text { lesion }\end{array}$ & Female & 70 & Grade 2 & $\begin{array}{l}\text { T3N1M0 } \\
\text { Stage III }\end{array}$ & Cancer-related \\
\hline Rectum & Male & 68 & Grade 2 & $\begin{array}{l}\text { T3N0M0 } \\
\text { Stage II }\end{array}$ & $\begin{array}{l}\text { Cancer-related } \\
\text { COD }\end{array}$ \\
\hline Sigmoid & Female & 74 & Grade 2 & $\begin{array}{l}\text { T4N1Mx } \\
\text { Stage III }\end{array}$ & Unknown \\
\hline Transverse & Female & 66 & Grade 2 & $\begin{array}{l}\text { T3N1M1 } \\
\text { Stage IV }\end{array}$ & Cancer-related \\
\hline Rectum & Male & 51 & Grade 2 & $\begin{array}{l}\text { T3N1M0 } \\
\text { Stage III }\end{array}$ & Unknown \\
\hline Sigmoid & Male & 59 & Grade 3 & $\begin{array}{l}\text { T3N1M0 } \\
\text { Stage III }\end{array}$ & Unknown \\
\hline Cecum & Female & 66 & Grade 2 & $\begin{array}{l}\text { T3N1M0 } \\
\text { Stage III }\end{array}$ & Cancer-related \\
\hline Descending & Female & 60 & Grade 4 & $\begin{array}{l}\text { T4N1M0 } \\
\text { Grade III }\end{array}$ & Cancer-related \\
\hline Cecum & Female & 77 & Grade 2 & $\begin{array}{l}\text { T2N1M0 } \\
\text { Stage III }\end{array}$ & $\begin{array}{l}\text { Not cancer- } \\
\text { related }\end{array}$ \\
\hline Rectum & Male & 71 & Grade 2 & $\begin{array}{l}\text { T3N1M0 } \\
\text { Stage III }\end{array}$ & Unknown \\
\hline Rectum & Male & 83 & Grade 3 & $\begin{array}{l}\text { T3N2M0 } \\
\text { Stage III }\end{array}$ & Unknown \\
\hline Ileocecal & Male & 81 & Grade 2 & $\begin{array}{l}\text { T2N2M0 } \\
\text { Stage III }\end{array}$ & Cancer-related \\
\hline Sigmoid & Male & 60 & Grade 2 & $\begin{array}{l}\text { T1N1M0 } \\
\text { Stage III }\end{array}$ & Unknown \\
\hline
\end{tabular}




\section{A.37 Characterization of Malignancies with Intact DNA Mismatch Repair Proteins (continued).}

\begin{tabular}{|c|c|c|c|c|c|}
\hline \multicolumn{6}{|c|}{$\begin{array}{l}\text { Table A.10. Characterization of Malignancies with Intact DNA } \\
\text { Mismatch Repair Proteins (continued) }\end{array}$} \\
\hline \multicolumn{3}{|c|}{ Patient Demographics } & \multirow{2}{*}{$\begin{array}{c}\text { WHO } \\
\text { Histologic } \\
\text { Grade } \\
\end{array}$} & \multirow{2}{*}{$\begin{array}{c}\text { AJCC } \\
\text { Staging }\end{array}$} & \multirow{2}{*}{$\begin{array}{l}\text { Cause of } \\
\text { Death }\end{array}$} \\
\hline Source & Gender & Age & & & \\
\hline Sigmoid & Male & 48 & $\begin{array}{l}\text { Grade } 2 \\
\text { (arising in } \\
\text { TA) }\end{array}$ & $\begin{array}{l}\text { T1N0M0 } \\
\text { Stage I }\end{array}$ & Unknown \\
\hline Ascending & Male & 69 & Grade 2 & $\begin{array}{l}\text { T2N0M0 } \\
\text { Stage I }\end{array}$ & Not applicable \\
\hline Cecum & Male & 62 & $\begin{array}{l}\text { Bx: in-situ } \\
\text { Grade } 4\end{array}$ & $\begin{array}{l}\text { T1N0Mx } \\
\text { Stage I }\end{array}$ & Not applicable \\
\hline Right colon & Female & 70 & Grade 2 & $\begin{array}{l}\text { T3N0M0 } \\
\text { Stage II }\end{array}$ & Unknown \\
\hline Ascending & Male & 67 & Grade 2 & $\begin{array}{l}\text { T2N0M0 } \\
\text { Stage I }\end{array}$ & $\begin{array}{l}\text { Not cancer- } \\
\text { related }\end{array}$ \\
\hline Rectum & Male & 68 & Grade 2 & $\begin{array}{l}\text { T1N0M0 } \\
\text { Stage I }\end{array}$ & Unknown \\
\hline Sigmoid & Male & 54 & Grade 2 & $\begin{array}{l}\text { T2N0M0 } \\
\text { Stage I }\end{array}$ & Not applicable \\
\hline Sigmoid & Female & 81 & Grade 2 & $\begin{array}{l}\text { T3N0M0 } \\
\text { Stage II }\end{array}$ & $\begin{array}{l}\text { Not cancer- } \\
\text { related }\end{array}$ \\
\hline Rectum & Male & 76 & Grade 2 & $\begin{array}{l}\text { T3N0M0 } \\
\text { Stage II }\end{array}$ & Not applicable \\
\hline Sigmoid & Male & 78 & Grade 2 & $\begin{array}{l}\text { T3N0M0 } \\
\text { Stage II }\end{array}$ & Cancer-related \\
\hline Transverse & Female & 48 & Grade 2 & $\begin{array}{l}\text { T3N0M0 } \\
\text { Stage II }\end{array}$ & Unknown \\
\hline Sigmoid & Male & 48 & Grade 3 & $\begin{array}{l}\text { T2N0M0 } \\
\text { Stage I }\end{array}$ & Unknown \\
\hline Ascending & Female & 48 & Grade 2 & $\begin{array}{l}\text { T3N0M0 } \\
\text { Stage II }\end{array}$ & Not applicable \\
\hline Ascending & Male & 67 & Grade 2 & $\begin{array}{l}\text { T2N0M0 } \\
\text { Stage I }\end{array}$ & Unknown \\
\hline Rectum & Female & 83 & Grade 2 & $\begin{array}{l}\text { T3N0M0 } \\
\text { Stage II }\end{array}$ & Not applicable \\
\hline Transverse & Male & 82 & Grade 2 & $\begin{array}{l}\text { T4N0M0 } \\
\text { Stage II }\end{array}$ & Cancer-related \\
\hline $\begin{array}{l}\text { Left colon, } \\
\text { NOS }\end{array}$ & Female & 73 & Grade 2 & $\begin{array}{l}\text { T1N0Mx } \\
\text { Stage I }\end{array}$ & Unknown \\
\hline
\end{tabular}




\section{A.38 Characterization of Malignancies with Intact DNA Mismatch Repair Proteins (continued).}

\begin{tabular}{|c|c|c|c|c|c|}
\hline \multicolumn{3}{|c|}{ Patient Demographics } & $\begin{array}{l}\text { WHO } \\
\text { Grade }\end{array}$ & $\begin{array}{c}\text { AJCC } \\
\text { Staging }\end{array}$ & $\begin{array}{c}\text { Cause of } \\
\text { Death }\end{array}$ \\
\hline Source & Gender & Age & & & \\
\hline Splenic flexure & Male & 64 & Grade 1 & $\begin{array}{l}\text { T3N0M0 } \\
\text { Stage II }\end{array}$ & Unknown \\
\hline Rectum & Male & 55 & Grade 2 & $\begin{array}{l}\text { T2N0M0 } \\
\text { Stage I }\end{array}$ & Unknown \\
\hline Splenic flexure & Male & 65 & $\begin{array}{l}\text { Grade } 2 \\
\text { (in TA) }\end{array}$ & $\begin{array}{l}\text { T2N0M0 } \\
\text { Stage I }\end{array}$ & Not applicable \\
\hline Sigmoid & Male & 68 & $\begin{array}{l}\text { Grade } 3 \text { (in } \\
\text { TA) }\end{array}$ & $\begin{array}{l}\text { T1N0M0 } \\
\text { Stage I }\end{array}$ & Cancer-related \\
\hline Rectum & Male & 56 & Grade 2 & $\begin{array}{l}\text { T3NxMx } \\
\text { Stage II }\end{array}$ & Cancer-related \\
\hline Ascending & Female & 83 & Grade 2 & $\begin{array}{l}\text { T2N0M0 } \\
\text { Stage I }\end{array}$ & $\begin{array}{l}\text { Not cancer- } \\
\text { related }\end{array}$ \\
\hline Ascending & Female & 86 & Grade 2 & $\begin{array}{l}\text { T1N0M0 } \\
\text { Stage I }\end{array}$ & Cancer-related \\
\hline Ascending & Male & 67 & Grade 2 & $\begin{array}{l}\text { T2N0M0 } \\
\text { Stage I }\end{array}$ & Unknown \\
\hline Sigmoid & Male & 56 & Grade 2 & $\begin{array}{l}\text { T2N0M0 } \\
\text { Stage I }\end{array}$ & $\begin{array}{l}\text { Not cancer- } \\
\text { related }\end{array}$ \\
\hline Transverse & Female & 69 & Grade 3 & $\begin{array}{l}\text { T3N0M0 } \\
\text { Stage II }\end{array}$ & Deceased \\
\hline Rectum & Male & 33 & Grade 2 & $\begin{array}{l}\text { T2N0M0 } \\
\text { Stage I }\end{array}$ & Unknown \\
\hline Transverse & Female & 76 & Grade 4 & $\begin{array}{l}\text { T3N0M0 } \\
\text { Stage II }\end{array}$ & Cancer-related \\
\hline Ileocecal & Male & 55 & Grade 3 & $\begin{array}{l}\text { T3N0M0 } \\
\text { Stage II }\end{array}$ & Unknown \\
\hline Rectum & Female & 65 & Grade 2 & $\begin{array}{l}\text { T3N0M0 } \\
\text { Stage II }\end{array}$ & Cancer-related \\
\hline Sigmoid & Male & 83 & Grade 2 & $\begin{array}{l}\text { T2N0M0 } \\
\text { Stage I }\end{array}$ & Unknown \\
\hline Hepatic flexure & Male & 84 & Grade 2 & $\begin{array}{l}\text { T2N0M0 } \\
\text { Stage I }\end{array}$ & Cancer-related \\
\hline Cecum & Male & 76 & Grade 2 & $\begin{array}{l}\text { T1N0M0 } \\
\text { Stage I }\end{array}$ & Cancer-related \\
\hline Colon, NOS & Male & 75 & Grade 2 & $\begin{array}{l}\text { T3N0M0 } \\
\text { Stage II }\end{array}$ & $\begin{array}{l}\text { Not cancer- } \\
\text { related }\end{array}$ \\
\hline Transverse & Male & 64 & Grade 3 & $\begin{array}{l}\text { T3N0M0 } \\
\text { Stage II }\end{array}$ & Cancer-related \\
\hline Transverse & Male & 72 & Grade 2 & $\begin{array}{l}\text { T3N0M0 } \\
\text { Stage II }\end{array}$ & $\begin{array}{l}\text { Not cancer- } \\
\text { related }\end{array}$ \\
\hline
\end{tabular}




\section{A.39 Characterization of Malignancies with Intact DNA Mismatch Repair Proteins (continued).}

\begin{tabular}{|c|c|c|c|c|c|}
\hline \multicolumn{3}{|c|}{ Patient Demographics } & $\begin{array}{l}\text { WHO } \\
\text { Grade }\end{array}$ & $\begin{array}{c}\text { AJCC } \\
\text { Staging }\end{array}$ & $\begin{array}{c}\text { Cause of } \\
\text { Death }\end{array}$ \\
\hline Source & Gender & Age & & & \\
\hline Cecum & Female & 55 & Grade 2 & $\begin{array}{l}\text { T2N0M0 } \\
\text { Stage I }\end{array}$ & Not applicable \\
\hline Transverse & Female & 84 & Grade 3 & $\begin{array}{l}\text { T1N0M0 } \\
\text { Stage I }\end{array}$ & $\begin{array}{l}\text { Not cancer- } \\
\text { related }\end{array}$ \\
\hline Ascending & Female & 66 & Grade 3 & $\begin{array}{l}\text { T1N0M0 } \\
\text { Stage I }\end{array}$ & Unknown \\
\hline Rectum & Male & 72 & Grade 2 & $\begin{array}{l}\text { T1N0M0 } \\
\text { Stage I }\end{array}$ & Unknown \\
\hline Cecum & Male & 62 & Grade 3 & $\begin{array}{l}\text { T3N0M0 } \\
\text { Stage II }\end{array}$ & Unknown \\
\hline Sigmoid & Male & 80 & Grade 2 & $\begin{array}{l}\text { T3N0M0 } \\
\text { Stage II }\end{array}$ & $\begin{array}{l}\text { Not cancer- } \\
\text { related }\end{array}$ \\
\hline Cecum & Male & 57 & Grade 3 & $\begin{array}{l}\text { T3N0M0 } \\
\text { Stage II }\end{array}$ & Unknown \\
\hline Ascending & Female & 78 & Grade 4 & $\begin{array}{l}\text { T3N0M0 } \\
\text { Stage II }\end{array}$ & Cancer-related \\
\hline Transverse & Female & 75 & Grade 2 & $\begin{array}{l}\text { T3N0M0 } \\
\text { Stage II }\end{array}$ & Cancer-related \\
\hline Cecum & Male & 83 & Grade 2 & $\begin{array}{l}\text { T1N0M0 } \\
\text { Stage I }\end{array}$ & Cancer-related \\
\hline Hepatic flexure & Female & 66 & Grade 2 & $\begin{array}{l}\text { T3N0M0 } \\
\text { Stage II }\end{array}$ & Cancer-related \\
\hline Right colon & Male & 68 & Grade 2 & $\begin{array}{l}\text { T1N0M0 } \\
\text { Stage I }\end{array}$ & $\begin{array}{l}\text { Not cancer- } \\
\text { related }\end{array}$ \\
\hline Splenic flexure & Male & 89 & Grade 2 & $\begin{array}{l}\text { T4N0M0 } \\
\text { Stage II }\end{array}$ & Cancer-related \\
\hline Colon, NOS & Male & 51 & Grade 2 & $\begin{array}{l}\text { T3N0M0 } \\
\text { Stage II }\end{array}$ & Cancer-related \\
\hline Rectum & Male & 73 & Grade 2 & $\begin{array}{l}\text { T3N0M0 } \\
\text { Stage II }\end{array}$ & Unknown \\
\hline Hepatic flexure & Male & 52 & Grade 2 & $\begin{array}{l}\text { T3N0M0 } \\
\text { Stage II }\end{array}$ & Unknown \\
\hline Right colon & Female & 73 & Grade 2 & $\begin{array}{l}\text { T3N0M0 } \\
\text { Stage II }\end{array}$ & Unknown \\
\hline Sigmoid & Male & 58 & Grade 1 & $\begin{array}{l}\text { T1N0M0 } \\
\text { Stage I }\end{array}$ & $\begin{array}{l}\text { Not cancer- } \\
\text { related }\end{array}$ \\
\hline Appendix & Male & 60 & Grade 2 & $\begin{array}{l}\text { T1N0M0 } \\
\text { Stage I }\end{array}$ & $\begin{array}{l}\text { Not cancer- } \\
\text { related }\end{array}$ \\
\hline Splenic flexure & Female & 87 & Grade 2 & $\begin{array}{l}\text { T3N0M0 } \\
\text { Stage II }\end{array}$ & $\begin{array}{l}\text { Not cancer- } \\
\text { related }\end{array}$ \\
\hline
\end{tabular}




\section{A.40 Characterization of Malignancies with Intact DNA Mismatch Repair Proteins (continued).}

\begin{tabular}{|c|c|c|c|c|c|}
\hline \multicolumn{3}{|c|}{ Patient Demographics } & $\begin{array}{l}\text { WHO } \\
\text { Grade }\end{array}$ & $\begin{array}{c}\text { AJCC } \\
\text { Staging }\end{array}$ & Cause of Death \\
\hline Source & Gender & Age & & & \\
\hline Rectum & Female & 90 & $\begin{array}{l}2004 \\
\text { Bx: } \\
\text { grade } 2 \\
\text { Resection: } \\
\text { Grade 2 } \\
2005 \\
\text { Grade } 3\end{array}$ & $\begin{array}{l}\text { Not } \\
\text { staged } \\
\text { T3NxMx } \\
\text { Stage II } \\
\text { T3N0M0 } \\
\text { Stage II }\end{array}$ & Cancer-related \\
\hline $\begin{array}{l}\text { Sigmoid and } \\
\text { Rectum }\end{array}$ & Female & 70 & $\begin{array}{l}\text { Sigmoid: } \\
\text { Grade } 2 \\
\text { Rectum: } \\
\text { Grade } 2 \\
\text { Rectum } \\
\text { Grade } 2\end{array}$ & $\begin{array}{l}\text { T3N2Mx } \\
\text { T3N2Mx } \\
\text { Stage III } \\
\text { T3N2Mx } \\
\text { Stage III }\end{array}$ & Cancer-related \\
\hline $\begin{array}{l}\text { B3- Sigmoid } \\
\text { /ulcerating } \\
\text { lesion } \\
\text { B9- Sigmoid/ } \\
\text { proximal to } \\
\text { original bx site }\end{array}$ & Female & 74 & $\begin{array}{l}\text { Grade } 3 \\
\text { High-grade } \\
\text { dysplasia }\end{array}$ & $\begin{array}{l}\text { T2N0Mx } \\
\text { Stage I }\end{array}$ & Unknown \\
\hline $\begin{array}{l}\text { B1-Ileocecal } \\
\text { D1- Sigmoid } \\
\text { Resection: } \\
\text { Sigmoid }\end{array}$ & Male & 74 & $\begin{array}{l}\text { Grade } 2 \\
\text { Grade } 2 \\
\text { Grade } 2\end{array}$ & $\begin{array}{l}\text { TisNxMx } \\
\text { Stage } 0 \\
\text { TisNxMx } \\
\text { Stage } 0 \\
\text { T1N0M0 } \\
\text { Stage I }\end{array}$ & Unknown \\
\hline $\begin{array}{l}\text { \#3-Cecum } \\
\text { \#8- Right }\end{array}$ & Male & 83 & $\begin{array}{l}\text { Both are } \\
\text { Grade } 2\end{array}$ & $\begin{array}{l}\text { Block \#3 } \\
\text { T2N0mx } \\
\text { Stage I } \\
\text { Block \#8 } \\
\text { T1N0Mx } \\
\text { Stage I }\end{array}$ & Unknown \\
\hline $\begin{array}{l}\text { Descending } \\
\text { Blocks \#3 } \\
\text { Block \#8 } \\
\end{array}$ & Male & 78 & Grade 2 & $\begin{array}{l}\text { T4N2M0 } \\
\text { Stage III }\end{array}$ & Cancer-related \\
\hline
\end{tabular}




\section{A.41 Characterization of Malignancies with Deficient DNA Mismatch Repair Proteins Demonstrating a Loss of MLH1/PMS2.}

\begin{tabular}{|c|c|c|c|c|c|}
\hline \multicolumn{6}{|c|}{$\begin{array}{l}\text { Table A.11. Characterization of Malignancies with Deficient DNA } \\
\text { Mismatch Repair Proteins Demonstrating a Loss of MLH1/PMS2 }\end{array}$} \\
\hline \multicolumn{3}{|c|}{ Patient Demographics } & \multirow[t]{2}{*}{$\begin{array}{l}\text { WHO } \\
\text { Grade }\end{array}$} & \multirow[t]{2}{*}{$\begin{array}{c}\text { AJCC } \\
\text { Staging }\end{array}$} & \multirow[t]{2}{*}{$\begin{array}{c}\text { Cause of } \\
\text { Death }\end{array}$} \\
\hline Source & Gender & Age & & & \\
\hline Cecum & Female & 81 & Grade 3 & $\begin{array}{l}\text { T4N2M0 } \\
\text { Stage III }\end{array}$ & $\begin{array}{l}\text { Not cancer- } \\
\text { related }\end{array}$ \\
\hline Cecum & Female & 72 & Grade 2 & $\begin{array}{l}\text { T3N2N0 } \\
\text { Stage III }\end{array}$ & Unknown \\
\hline Cecum & Female & 73 & Grade 2 & $\begin{array}{l}\text { T4N2M0 } \\
\text { Stage III }\end{array}$ & Unknown \\
\hline Ascending & Female & 90 & Grade 3 & $\begin{array}{l}\text { T3N2M0 } \\
\text { Stage III }\end{array}$ & Unknown \\
\hline Right colon & Female & 80 & Grade 2 & $\begin{array}{l}\text { T2N0M0 } \\
\text { Stage I }\end{array}$ & Unknown \\
\hline Sigmoid & Female & 82 & Grade 2 & $\begin{array}{l}\text { T1N0M0 } \\
\text { Stage I }\end{array}$ & $\begin{array}{l}\text { Cancer-related } \\
\text { death }\end{array}$ \\
\hline Hepatic flexure & Male & 76 & Grade 2 & $\begin{array}{l}\text { T3N0M0 } \\
\text { Stage II }\end{array}$ & $\begin{array}{l}\text { Not cancer- } \\
\text { related }\end{array}$ \\
\hline Right colon & Male & 83 & Grade 2 & $\begin{array}{l}\text { T3N0Mx } \\
\text { Stage II }\end{array}$ & Cancer-related \\
\hline Transverse & Male & 51 & Grade 2 & $\begin{array}{l}\text { T2N0mx } \\
\text { Stage I }\end{array}$ & Not applicable \\
\hline Transverse & Male & 72 & Grade 2 & $\begin{array}{l}\text { T4N0M0 } \\
\text { Stage II }\end{array}$ & $\begin{array}{l}\text { Not cancer- } \\
\text { related }\end{array}$ \\
\hline Hepatic flexure & Male & 56 & Grade 2 & $\begin{array}{l}\text { T3N0M0 } \\
\text { Stage II }\end{array}$ & Cancer-related \\
\hline Ascending & Female & 87 & Grade 2 & $\begin{array}{l}\text { T3N0M0 } \\
\text { Stage II }\end{array}$ & Cancer-related \\
\hline Descending & Female & 69 & Grade 2 & $\begin{array}{l}\text { T2N0M0 } \\
\text { Stage I }\end{array}$ & Cancer-related \\
\hline Ascending & Female & 86 & Grade 3 & $\begin{array}{l}\text { T3N0M0 } \\
\text { Stage II }\end{array}$ & $\begin{array}{l}\text { Not cancer- } \\
\text { related }\end{array}$ \\
\hline Cecum & Male & 66 & Grade 2 & $\begin{array}{l}\text { T3N0M0 } \\
\text { Stage II }\end{array}$ & Unknown \\
\hline Sigmoid & Male & 64 & Grade 2 & $\begin{array}{l}\text { T3N0M0 } \\
\text { Stage II }\end{array}$ & Unknown \\
\hline Right & Male & 62 & Grade 2 & $\begin{array}{l}\text { T3N0M0 } \\
\text { Stage II }\end{array}$ & Not applicable \\
\hline Colon & Female & 67 & Grade 2 & $\begin{array}{l}\text { T3N0M0 } \\
\text { Stage II }\end{array}$ & Cancer-related \\
\hline Transverse & Female & 83 & Grade 3 & $\begin{array}{l}\text { T4N0M0 } \\
\text { Stage II }\end{array}$ & $\begin{array}{l}\text { Not cancer- } \\
\text { related }\end{array}$ \\
\hline
\end{tabular}




\section{A.42 Characterization of Malignancies with Deficient DNA Mismatch Repair Proteins Demonstrating a Loss of MLH1/PMS2 (continued).}

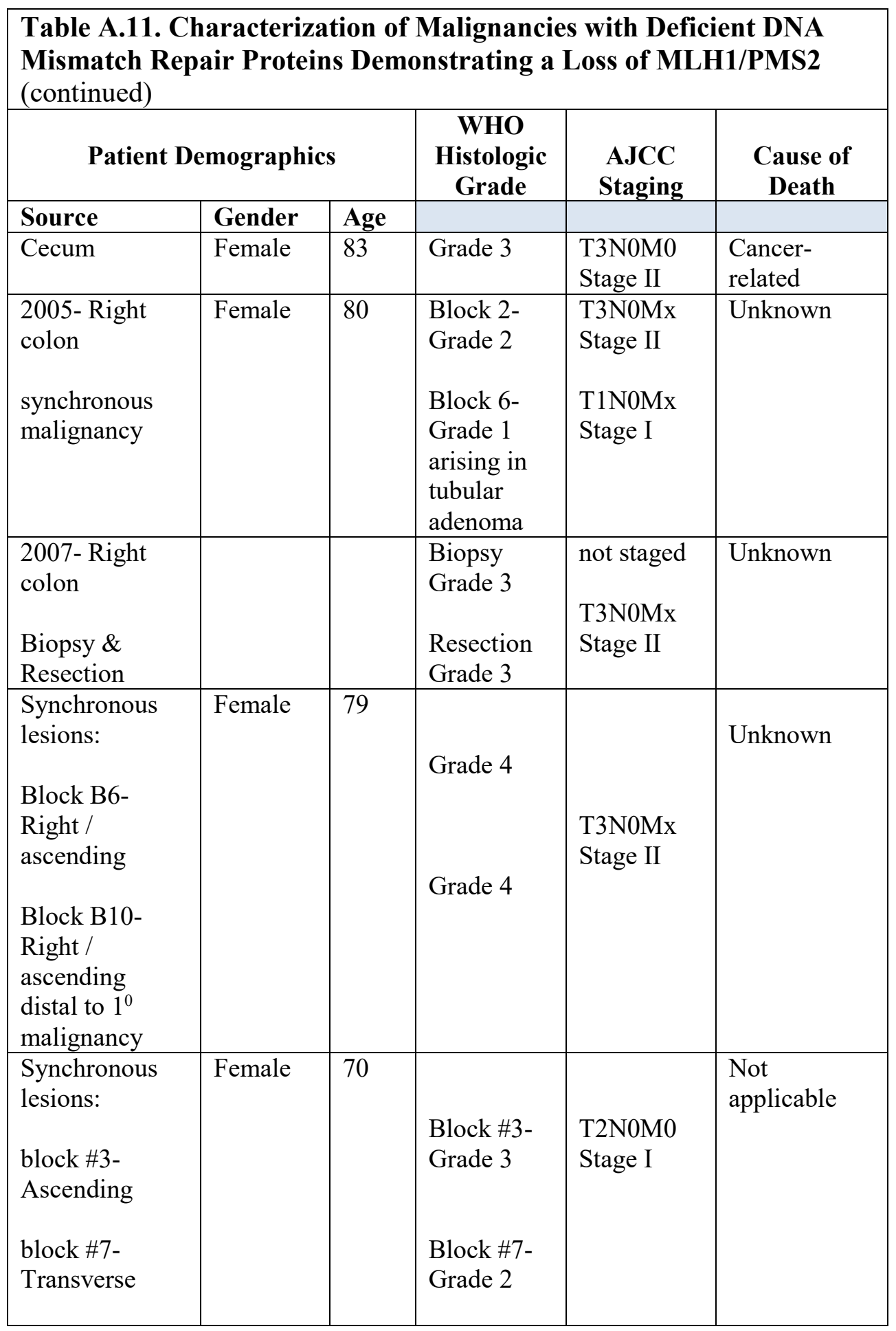




\section{A.43 Characterization of Malignancies with Deficient DNA Mismatch Repair Proteins Demonstrating a Loss of One Repair Protein.}

\begin{tabular}{|c|c|c|c|c|c|}
\hline \multicolumn{6}{|c|}{$\begin{array}{l}\text { Table A.12. Characterization of Malignancies with Deficient DNA } \\
\text { Mismatch Repair Proteins Demonstrating a Loss of One Repair } \\
\text { Protein }\end{array}$} \\
\hline \multicolumn{3}{|c|}{ Patient Demographics } & $\begin{array}{c}\text { WHO } \\
\text { Histologic } \\
\text { Grade }\end{array}$ & $\begin{array}{l}\text { AJCC } \\
\text { Stagino }\end{array}$ & Cause of Death \\
\hline Source & Gender & Age & & & \\
\hline Splenic flexure & Female & 67 & Grade 2 & T4N0M0 & Cancer-related \\
\hline Cecum & Male & 88 & Grade 2 & $\begin{array}{l}\text { T2N0M0 } \\
\text { Stage I }\end{array}$ & Cancer-related \\
\hline Right colon & Male & 53 & Grade 2 & $\begin{array}{l}\text { T3N0M0 } \\
\text { Stage II }\end{array}$ & Not applicable \\
\hline Ascending & Female & 79 & Grade 4 & $\begin{array}{l}\text { T3N0Mx } \\
\text { Stage II }\end{array}$ & Unknown \\
\hline
\end{tabular}

\section{A.44 Positive PD-L1 Expression in Colon Resection and Matched Lymph Node.}
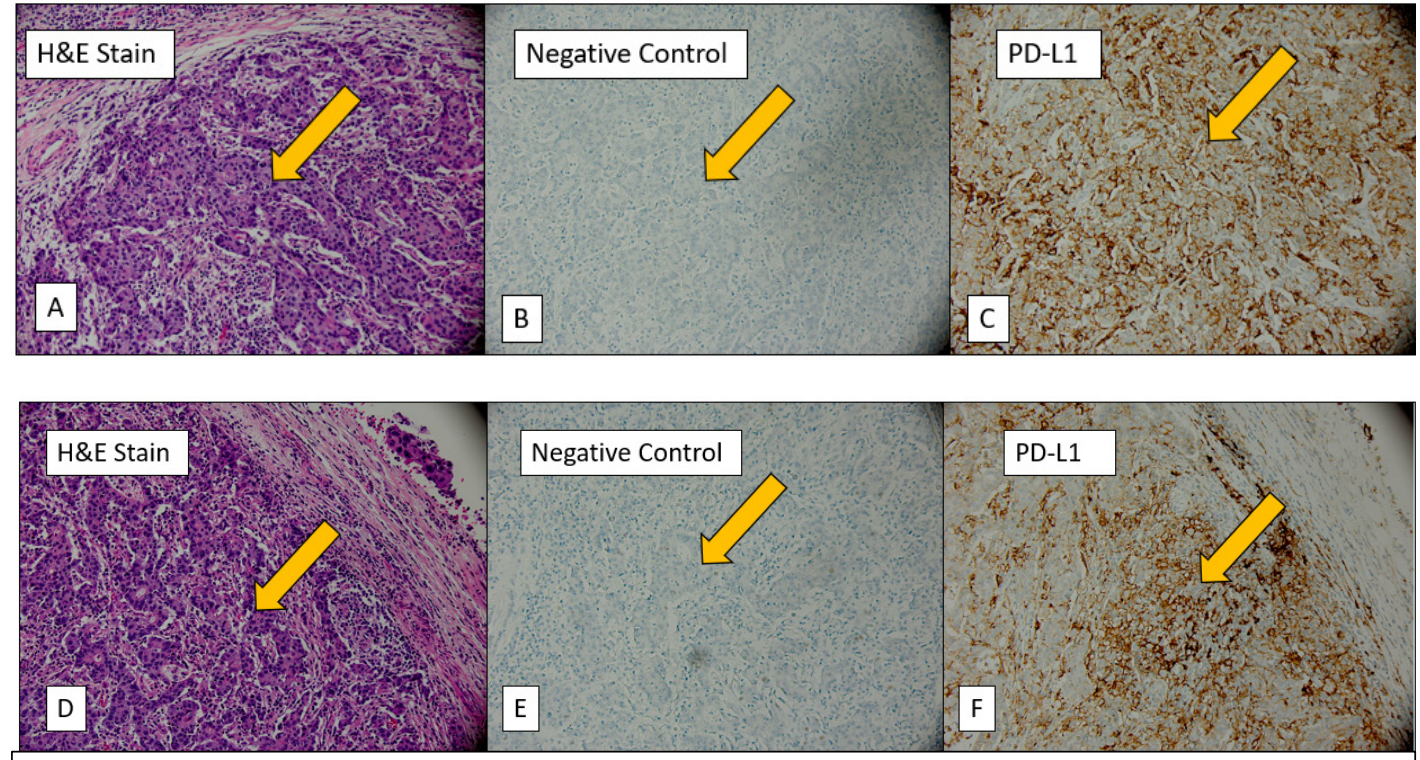

Figure A.11. Positive PD-L1 Expression in Colon Resection and Matched mCRC in Lymph Node: a) Hematoxylin \& Eosin stain (arrow denotes) malignant cells, b) Rabbit monoclonal negative reagent control c) Positive membranous staining in $70-89 \%$ of tumor cells, d) Hematoxylin \& Eosin stained lymph node belonging to the same patient, e) Rabbit monoclonal negative reagent control, f) Positive membranous staining in $90-100 \%$ of tumor cells. All images were taken at 40x magnification. 


\section{A.45 Negative PD-L1 Expression in Colon Resection and Matched mCRC in Lymph Node.}
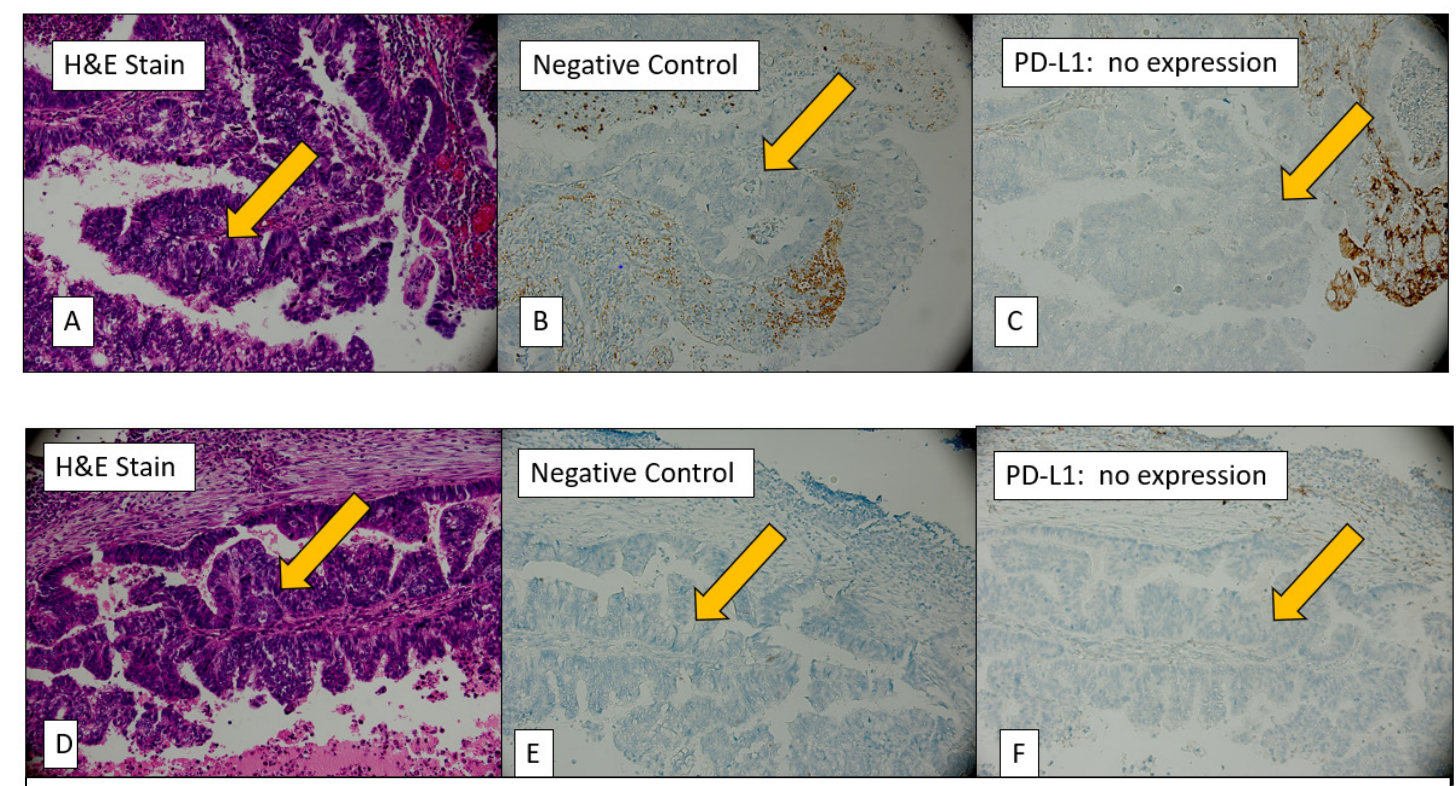

Figure A.12. Negative PD-L1 Expression in Colon Resection and Matched $\mathbf{m C R C}$ in Lymph Node: a) Hematoxylin \& Eosin stain (arrow denotes) malignant cells, b) Rabbit monoclonal negative reagent control with endogenous background staining noted, c) Negative membranous staining in tumor cells but positive staining in macrophages in microenvironment (internal positive control) d) Hematoxylin \& Eosin stained lymph node with $\mathrm{mCRC}$ belonging to the same patient, e) Rabbit monoclonal negative reagent control, f) Negative membranous staining of tumor cells. Staining of tumor-infiltrating immune cells is noted. All images were taken at 40x magnification. 


\section{A.46 Characterization of PD-L1 and Clinicopathological Features in Patient Cohort.}

\section{Table A.13. Characterization of PD-L1 and Clinicopathological Features in}

Patient Cohort.

PD-L1 Expression levels varied among matched samples in the cohort. PD-L1 expression was observed more frequently in tumors arising in the sigmoid and proximal colon. Tumors demonstrating the greatest percentage of PD-L1 arose in the cecum.

\begin{tabular}{|c|c|c|c|c|c|c|c|}
\hline \multirow{2}{*}{\begin{tabular}{l}
\multicolumn{1}{c}{ Score } \\
$1-9 \%$ \\
expression \\
in TC
\end{tabular}} & \multicolumn{3}{|c|}{ Patient Demographics } & \multirow{2}{*}{$\begin{array}{l}\text { WHO } \\
\text { Histological } \\
\text { Grade }\end{array}$} & \multirow{2}{*}{$\begin{array}{c}\text { AJCC } \\
\text { Staging }\end{array}$} & \multirow{2}{*}{$\begin{array}{l}\text { Cause of } \\
\text { Death }\end{array}$} & \multirow[t]{2}{*}{ Characteristics of Matched Samples } \\
\hline & Source & Gender & $\begin{array}{l}\text { Age of } \\
\text { Patient }\end{array}$ & & & & \\
\hline & Cecum & Male & 70 & Grade 2 & $\begin{array}{l}\text { T3N2M1 } \\
\text { Stage IV }\end{array}$ & $\begin{array}{l}\text { Cancer- } \\
\text { related }\end{array}$ & $\begin{array}{l}\text { Resection and Node } \\
\text { MMR Intact }\end{array}$ \\
\hline & Sigmoid & Male & 49 & Grade 2 & $\begin{array}{l}\text { T3N1M0 } \\
\text { Stage III }\end{array}$ & Unknown & $\begin{array}{l}\text { Resection } \\
\text { MMR Intact }\end{array}$ \\
\hline & Sigmoid & Female & 82 & Grade 2 & $\begin{array}{l}\text { T1NOM0 } \\
\text { Stage I }\end{array}$ & $\begin{array}{l}\text { Cancer- } \\
\text { related }\end{array}$ & $\begin{array}{l}\text { Bx 1-9\%, Resection 1-9\% expression } \\
\text { deficient (loss of MLH1/PMS2) } \\
\text { BRAF V600E }\end{array}$ \\
\hline & Right colon & Male & 83 & Grade 2 & $\begin{array}{l}\text { T3NOMx } \\
\text { Stage II }\end{array}$ & $\begin{array}{l}\text { Cancer- } \\
\text { related }\end{array}$ & $\begin{array}{l}\text { Bx }<1 \% \text {; Resection 1-9\% } \\
\text { MMR deficient (lo5s of MLH1/PMS2) } \\
\text { BRAF V600E }\end{array}$ \\
\hline & $\begin{array}{l}\text { Splenic } \\
\text { flexure }\end{array}$ & Male & 64 & Grade 1 & $\begin{array}{l}\text { T3NOMO } \\
\text { Stage II }\end{array}$ & Unknown & $\begin{array}{l}\text { Resection; MSS } \\
\text { BRAF V600E }\end{array}$ \\
\hline & Sigmoid & Male & 68 & Grade 3 & $\begin{array}{l}\text { T1NOM0 } \\
\text { Stage I }\end{array}$ & $\begin{array}{l}\text { Cancer- } \\
\text { related }\end{array}$ & Resection; MSS \\
\hline & Cecum & Female & 83 & Grade 3 & $\begin{array}{l}\text { T3NOMO } \\
\text { Stage II }\end{array}$ & $\begin{array}{l}\text { Cancer- } \\
\text { related }\end{array}$ & $\begin{array}{l}\text { Resection; deficient (loss of } \\
\text { MLH1/PMS2) } \\
\text { BRAF V600E }\end{array}$ \\
\hline & $\begin{array}{l}\text { Sigmoid } \\
\text { \& Rectum }\end{array}$ & Female & 70 & $\begin{array}{l}2005 \\
\text { Sigmoid, grade } \\
2 \\
2006, \text { Rectum } \\
\text { Grade 2 } \\
2007 \\
\text { Rectum } \\
\text { Grade2 }\end{array}$ & $\begin{array}{l}\text { T3N2Mx } \\
\text { Stage III } \\
\text { T3N2Mx } \\
\text { Stage III } \\
\\
\\
\text { T3N2Mx } \\
\text { Stage III }\end{array}$ & $\begin{array}{l}\text { Cancer- } \\
\text { related }\end{array}$ & $\begin{array}{l}\text { 1-9\% expression in resection, no } \\
\text { expression in nodes } \\
\text { No expression } \\
\text { No expression }\end{array}$ \\
\hline
\end{tabular}




\section{A.47 Characterization of PD-L1 and Clinicopathological Features in Patient Cohort (continued).}

Table A.13. Characterization of PD-L1 and Clinicopathological Features in Patient Cohort (continued)

\begin{tabular}{|c|c|c|c|c|c|c|c|}
\hline Score & \multicolumn{3}{|c|}{ Patient Demographics } & $\begin{array}{c}\text { WHO } \\
\text { Histological }\end{array}$ & AJCC & Cause of & Notes \\
\hline \multirow[t]{3}{*}{$\begin{array}{l}10-29 \% \\
\text { expression } \\
\text { in TC }\end{array}$} & Source & $\begin{array}{l}\text { Sex of } \\
\text { Patient }\end{array}$ & $\begin{array}{l}\text { Age of } \\
\text { Patient }\end{array}$ & & & & \\
\hline & Appendix & Male & 60 & Grade 2 & $\begin{array}{l}\text { T1N0M0 } \\
\text { Stage I }\end{array}$ & $\begin{array}{l}\text { Not } \\
\text { cancer- } \\
\text { related }\end{array}$ & Resection; MSS \\
\hline & $\begin{array}{l}\text { Right } \\
\text { Colon }\end{array}$ & Female & 80 & $\begin{array}{l}2005 \\
\text { malignancy } \\
\text { Block 2: Grade } \\
2 \\
\text { Block 6: } \\
\text { Grade 1 } \\
2007 \\
\text { Bx: grade } 3 \\
\text { Resection: } \\
\text { Grade 3 }\end{array}$ & $\begin{array}{l}\text { T3NOMx } \\
\text { Stage II } \\
\text { T1NOMx } \\
\text { Stage I } \\
\text { Not } \\
\text { graded } \\
\text { T3NOMx } \\
\text { Stage II }\end{array}$ & $\begin{array}{l}\text { Cancer- } \\
\text { related }\end{array}$ & $\begin{array}{l}\text { 10-29\% expression } \\
\text { 1-9\% expression } \\
\text { 1-9\% expression } \\
\text { BRAF V600E positive } \\
\text { 10-29\% expression; } \\
\text { BRAF V600E positive }\end{array}$ \\
\hline
\end{tabular}

\begin{tabular}{|l|l|l|l|l|l|l|l|}
\hline Score & \multicolumn{3}{|c|}{ Patient Demographics } & $\begin{array}{c}\text { WHO } \\
\text { Histological } \\
\text { Grade }\end{array}$ & $\begin{array}{c}\text { AJCC } \\
\text { Staging }\end{array}$ & $\begin{array}{l}\text { Cause of } \\
\text { Death }\end{array}$ & Notes \\
\hline $\begin{array}{l}\text { 30-100\% } \\
\text { expression } \\
\text { in TC }\end{array}$ & Source & $\begin{array}{l}\text { Sex of } \\
\text { Patient }\end{array}$ & $\begin{array}{l}\text { Age of } \\
\text { Patient }\end{array}$ & & & & \\
\hline & Cecum & Female & 81 & Grade 3 & $\begin{array}{l}\text { T4N2M0 } \\
\text { Stage III }\end{array}$ & $\begin{array}{l}\text { Not } \\
\text { cancer- } \\
\text { related }\end{array}$ & $\begin{array}{l}\text { Bx 30\%, colon 75\%, nodes 30\% } \\
\text { All dMMR: LossMLH1/PMS2 } \\
\text { BRAF V600E mutation }\end{array}$ \\
\hline & Cecum & Female & 72 & Grade 2 & $\begin{array}{l}\text { T3N2M0 } \\
\text { Stage III }\end{array}$ & Unknown & $\begin{array}{l}\text { Bx 30\%, colon 70\%, nodes 90\% } \\
\text { All dMMR: LossMLH1/PMS2 }\end{array}$ \\
\hline & & & & & & & \\
\hline
\end{tabular}




\section{A.48 Diversity of Mutations and Clinicopathological Features in Patients with Synchronous Malignancies.}

Table A.14. Diversity of Mutations and Clinicopathological Features in Patients with Synchronous Malignancies.

Twenty-nine percent of the patients in our cohort had malignancies in which multiple mutations were identified. Malignancies arising in the ascending colon demonstrated the greatest mutational diversity and the frequency of concomitant mutations gradually decreased from the transverse colon to the rectum.

\begin{tabular}{|c|c|c|c|c|c|c|c|}
\hline \multicolumn{3}{|c|}{$\begin{array}{c}\text { Patient } \\
\text { Demographics } \\
\text { Gender Age Source }\end{array}$} & $\begin{array}{l}\text { WHO } \\
\text { Grade }\end{array}$ & $\begin{array}{c}\text { AJCC } \\
\text { Staging }\end{array}$ & $\begin{array}{c}\text { Cause of } \\
\text { Death }\end{array}$ & $\begin{array}{l}\text { Summary of } \\
\text { Mutations: }\end{array}$ & $\begin{array}{l}\text { Treatment } \\
\text { Summary: }\end{array}$ \\
\hline Male & 74 & $\begin{array}{l}\text { B1- } \\
\text { Ileocecal } \\
\text { D1- } \\
\text { Sigmoid } \\
\text { Resection } \\
\text { Sigmoid }\end{array}$ & $\begin{array}{c}\text { Block } \\
\text { \#B1: } \\
\text { Grade } 2 \\
\text { Block } \\
\text { \#D1: } \\
\text { Grade 2 } \\
\text { Resection: } \\
\text { Grade 2 }\end{array}$ & $\begin{array}{l}\text { TisNxMx } \\
\text { Stage } 0 \\
\text { TisNxMx } \\
\text { Stage } 0 \\
\text { T1N0M0 } \\
\text { Stage1 }\end{array}$ & Unknown & $\begin{array}{l}\text { MMR Status: } \\
\text { Proficient / } \\
\text { intact. } \\
\text { PDL-1 } \\
\text { Expression: } \\
\text { no expression } \\
\text { in TC. } \\
\text { BRAF } \\
\text { mutation - No } \\
\text { mutation } \\
\text { identified via } \\
\text { IHC or PCR } \\
\text { KRAS } \\
\text { mutation } \\
\text { (PCR)- No } \\
\text { mutation } \\
\text { detected in any } \\
\text { of the samples. } \\
\text { PIK3CA } \\
\text { mutation } \\
\text { (PCR)- } \\
\text { No mutation } \\
\text { detected in any } \\
\text { of the samples. }\end{array}$ & $\begin{array}{l}\text { Colonoscopy } \\
\text { Right hemi- } \\
\text { colectomy } \\
\text { with lymph } \\
\text { node } \\
\text { dissection. } \\
\text { Observation. }\end{array}$ \\
\hline
\end{tabular}




\section{A.49 Diversity of Mutations and Clinicopathological Features in Patients with Synchronous Malignancies (continued).}

Table A.14. Diversity of Mutations and Clinicopathological Features in Patients with Synchronous Malignancies (continued)

\begin{tabular}{|c|c|c|c|c|c|c|c|}
\hline \multicolumn{3}{|c|}{$\begin{array}{l}\text { Patient Demographics } \\
\text { Gender Age Source }\end{array}$} & $\begin{array}{l}\text { WHO } \\
\text { Grade }\end{array}$ & $\begin{array}{c}\text { AJCC } \\
\text { Staging }\end{array}$ & $\begin{array}{c}\text { Cause of } \\
\text { Death }\end{array}$ & $\begin{array}{l}\text { Summary of } \\
\text { Mutations: }\end{array}$ & $\begin{array}{l}\text { Treatment } \\
\text { Summary: }\end{array}$ \\
\hline Male & 83 & $\begin{array}{l}\# 3- \\
\text { Cecum } \\
\text { \#8- Right }\end{array}$ & $\begin{array}{l}\text { Both } \\
\text { blocks, } \\
\# 3 \text { \& 8: } \\
\text { Grade } 2\end{array}$ & $\begin{array}{l}\text { Block \#3 } \\
\text { T2N0Mx } \\
\text { Stage I } \\
\\
\text { Block \#8 } \\
\text { T1N0Mx } \\
\text { Stage I }\end{array}$ & Unknown & $\begin{array}{l}\text { MMR Status: } \\
\text { Proficient / } \\
\text { intact. } \\
\text { PDL-1 } \\
\text { Expression: } \\
\text { no expression } \\
\text { in TC. } \\
\text { BRAF } \\
\text { mutation - No } \\
\text { mutation } \\
\text { identified via } \\
\text { IHC or PCR } \\
\text { KRAS } \\
\text { mutation } \\
\text { (PCR)- No } \\
\text { mutation } \\
\text { detected in any } \\
\text { of the samples. } \\
\text { PIK3CA } \\
\text { mutation } \\
\text { (PCR)- } \\
\text { No mutation } \\
\text { detected in any } \\
\text { of the samples. }\end{array}$ & $\begin{array}{l}\text { Colonoscopy } \\
\text { with biopsy; } \\
\text { Right hemi- } \\
\text { colectomy } \\
\text { with lymph } \\
\text { node } \\
\text { dissection. } \\
\text { Observation. }\end{array}$ \\
\hline
\end{tabular}




\section{A.50 Diversity of Mutations and Clinicopathological Features in Patients with Synchronous Malignancies (continued).}

Table A.14. Diversity of Mutations and Clinicopathological Features in Patients with Synchronous Malignancies (continued)

\begin{tabular}{|c|c|c|c|c|c|c|c|}
\hline \multicolumn{3}{|c|}{ Patient Demographics } & $\begin{array}{l}\text { WHO } \\
\text { Grade }\end{array}$ & $\begin{array}{l}\text { AJCC } \\
\text { Stage }\end{array}$ & $\begin{array}{l}\text { Cause } \\
\text { of } \\
\text { Death }\end{array}$ & $\begin{array}{l}\text { Summary of } \\
\text { Mutations: }\end{array}$ & $\begin{array}{l}\text { Treatment } \\
\text { Summary: }\end{array}$ \\
\hline Female & 70 & $\begin{array}{c}\# 3- \\
\text { Ascending } \\
\# 7- \\
\text { Transverse }\end{array}$ & $\begin{array}{c}\text { Block } \\
\# 3- \\
\text { Grade } \\
3 \\
\\
\text { Block } \\
\# 7- \\
\text { Grade } \\
2\end{array}$ & $\begin{array}{c}\text { Both } \\
\text { were } \\
\text { staged: } \\
\text { T2N0M0 } \\
\text { Stage I }\end{array}$ & $\mathrm{NA}$ & $\begin{array}{l}\text { MMR Status: } \\
\text { deficient; loss } \\
\text { of MLH1/PMS2 } \\
\text { in both samples. } \\
\text { PDL-1 } \\
\text { Expression: } \\
\text { no expression in } \\
\text { TC. } \\
\text { BRAF mutation } \\
\text { BRAF V600E } \\
\text { mutation } \\
\text { identified in } \\
\text { both samples } \\
\text { via IHC and } \\
\text { PCR } \\
\text { KRAS mutation } \\
\text { (PCR)- No } \\
\text { mutation } \\
\text { detected in } \\
\text { either sample. } \\
\text { PIK3CA } \\
\text { mutation } \\
\text { (PCR)- } \\
\text { No mutation } \\
\text { detected in } \\
\text { either sample. }\end{array}$ & $\begin{array}{l}\text { Colonoscopy; } \\
\text { Right } \\
\text { hemicolectomy } \\
\text { with lymph } \\
\text { node dissection. } \\
\text { Observation. }\end{array}$ \\
\hline
\end{tabular}




\section{A.51 Diversity of Mutations and Clinicopathological Features in Patients with Synchronous Malignancies (continued).}

Table A.14. Diversity of Mutations and Clinicopathological Features in Patients with Synchronous Malignancies (continued)

\begin{tabular}{|c|c|c|c|c|c|c|c|}
\hline \multicolumn{3}{|c|}{ Patient Demographics } & $\begin{array}{l}\text { WHO } \\
\text { Grade }\end{array}$ & $\begin{array}{l}\text { AJCC } \\
\text { Stage }\end{array}$ & $\begin{array}{c}\text { Cause } \\
\text { of } \\
\text { Death }\end{array}$ & $\begin{array}{l}\text { Characterization } \\
\text { of Mutations: }\end{array}$ & $\begin{array}{l}\text { Treatment } \\
\text { Summary: }\end{array}$ \\
\hline Male & 78 & Descending & $\begin{array}{l}\text { Blocks } \\
\# 3 \& 8 \\
\text { Grade } \\
2\end{array}$ & T4N2Mx & $\begin{array}{l}\text { Cancer- } \\
\text { related }\end{array}$ & $\begin{array}{c}\text { MMR Status: } \\
\text { Proficient/ intact } \\
\text { in both lesions. } \\
\text { PDL-1 } \\
\text { Expression: } \\
\text { Block \#3: <1\% } \\
\text { expression in TC; } \\
\text { Block \#8: no } \\
\text { expression in TC. } \\
\text { BRAF mutation- } \\
\text { No BRAF V600E } \\
\text { mutation } \\
\text { identified via IHC } \\
\text { or PCR in either } \\
\text { block. } \\
\text { KRAS mutation } \\
\text { (PCR)- } \\
\text { Block \#3- KRAS } \\
\text { mutation G12x } \\
\text { identified. } \\
\text { Block \#8: No } \\
\text { mutation } \\
\text { detected. } \\
\text { PIK3CA } \\
\text { mutation (PCR)- } \\
\text { Block \#3: No } \\
\text { mutation } \\
\text { detected. } \\
\text { Block \#8: } \\
\text { PIK3CA } \\
\text { mutation E545x } \\
\text { detected. }\end{array}$ & $\begin{array}{l}\text { Colonoscopy } \\
\text { with biopsies; } \\
\text { Left } \\
\text { hemicolectomy; } \\
\text { low anterior } \\
\text { resection with } \\
\text { ileostomy }\end{array}$ \\
\hline
\end{tabular}




\section{A.52 Diversity of Mutations and Clinicopathological Features in Patients with Synchronous Malignancies.}

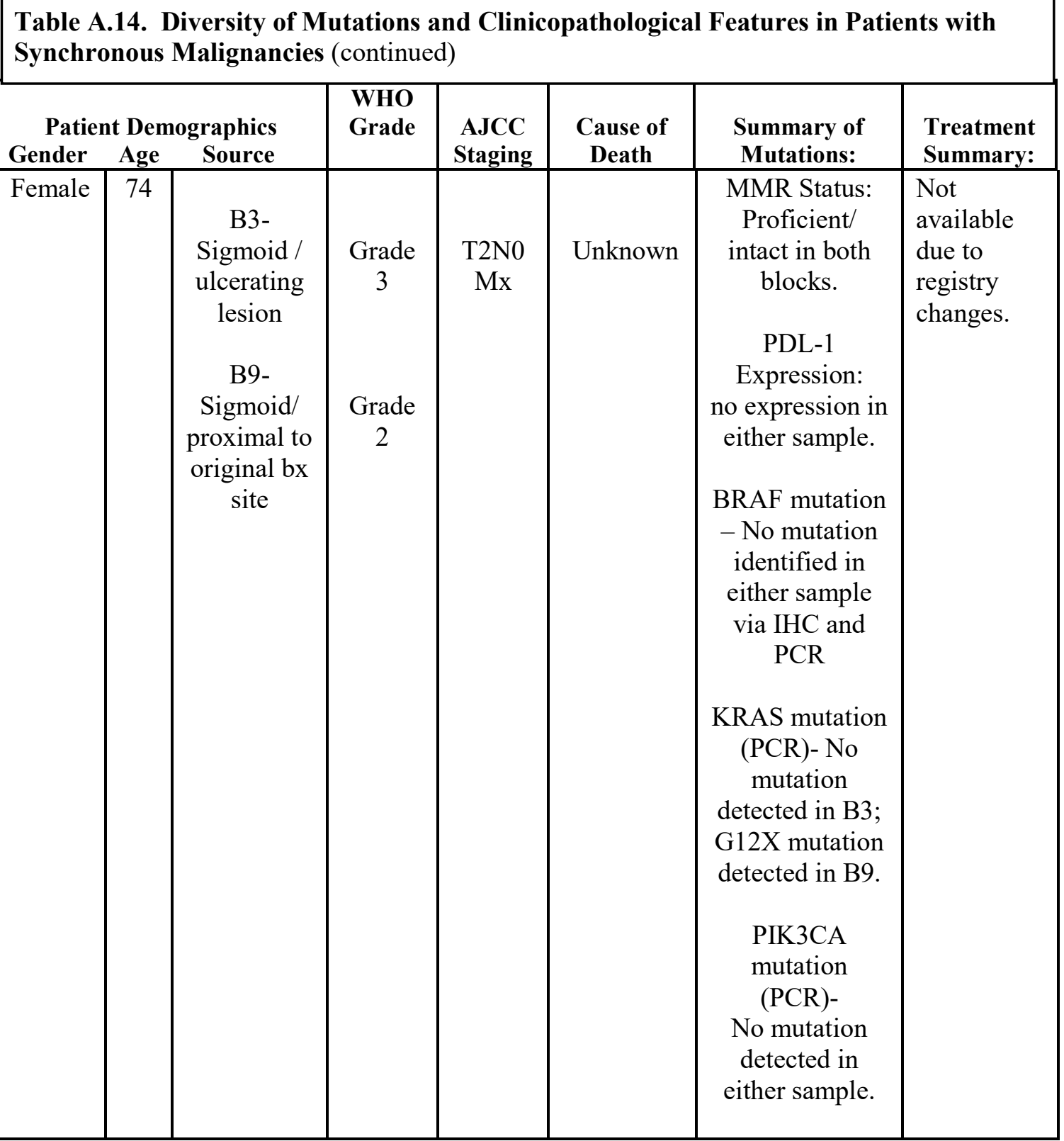




\section{A.53 Diversity of Mutations and Clinicopathological Features in Patients with Synchronous Malignancies (continued).}

Table A.14. Diversity of Mutations and Clinicopathological Features in Patients with Synchronous Malignancies (continued)

\begin{tabular}{|c|c|c|c|c|c|c|c|}
\hline \multicolumn{3}{|c|}{ Patient Demographics } & \multirow{2}{*}{$\begin{array}{c}\text { WHO } \\
\text { Grade } \\
\\
\text { Grade } \\
4\end{array}$} & \multirow{2}{*}{$\begin{array}{c}\text { AJCC } \\
\text { Staging } \\
\text { T3N0Mx }\end{array}$} & \multirow{2}{*}{$\begin{array}{c}\begin{array}{c}\text { Cause } \\
\text { of } \\
\text { Death }\end{array} \\
\begin{array}{c}\text { Not- } \\
\text { cancer- } \\
\text { related }\end{array}\end{array}$} & \multirow{2}{*}{$\begin{array}{c}\text { Summary of } \\
\text { Mutations: } \\
\text { Blocks \#B6 and } \\
\text { \#B10: } \\
\text { MSI- Status: } \\
\text { B6- Deficient / } \\
\text { loss MLH1/PMS2 } \\
\text { B10- Deficient / } \\
\text { loss MLH1 }\end{array}$} & \multirow{2}{*}{$\begin{array}{c}\text { Treatment } \\
\text { Summary: } \\
\text { Unavailable } \\
\text { due to } \\
\text { registry } \\
\text { changes. }\end{array}$} \\
\hline Gender & Ag & Source & & & & & \\
\hline Female & 79 & $\begin{array}{l}\text { B6- Right / } \\
\text { ascending } \\
\text { B10- Right } \\
\text { / ascending } \\
\text { distal to } 1^{0} \\
\text { malignancy }\end{array}$ & $\begin{array}{c}\text { Grade } \\
4\end{array}$ & T3N0Mx & $\begin{array}{l}\text { Not- } \\
\text { cancer- } \\
\text { related }\end{array}$ & $\begin{array}{c}\text { Blocks \#B6 and } \\
\text { \#B10: } \\
\text { MSI- Status: } \\
\text { B6- Deficient / } \\
\text { loss MLH1/PMS2 } \\
\text { B10- Deficient / } \\
\text { loss MLH1 } \\
\text { PDL-1 Expression: } \\
\text { no expression in } \\
\text { TC. } \\
\text { BRAF V600E } \\
\text { mutation - } \\
\text { B6- No mutation } \\
\text { identified via IHC } \\
\text { or PCR } \\
\text { B10- yielded } \\
\text { invalid results via } \\
\text { PCR; IHC stain } \\
\text { was negative. } \\
\text { KRAS mutation } \\
\text { (PCR)- No } \\
\text { mutation detected } \\
\text { in B6; B10 yielded } \\
\text { invalid results. } \\
\text { PIK3CA mutation } \\
\text { (PCR)- } \\
\text { E545x mutation } \\
\text { detected in both } \\
\text { samples. }\end{array}$ & $\begin{array}{l}\text { Unavailable } \\
\text { due to } \\
\text { registry } \\
\text { changes. }\end{array}$ \\
\hline
\end{tabular}




\section{A.54 Diversity of Mutations and Clinicopathological Features in Patients with Recurrent Malignancies.}

Table A.15. Diversity of Mutations and Clinicopathological Features in Patients with Recurrent Malignancies.

Recurrent malignancies demonstrated mutations that were similar to the original malignancy.

\begin{tabular}{|c|c|c|c|c|c|c|c|}
\hline \multicolumn{3}{|c|}{ Patient Demographics } & \multirow[t]{2}{*}{$\begin{array}{l}\text { WHO } \\
\text { Grade }\end{array}$} & \multirow[t]{2}{*}{$\begin{array}{c}\text { AJCC } \\
\text { Staging }\end{array}$} & \multirow{2}{*}{$\begin{array}{c}\text { Cause } \\
\text { of } \\
\text { Death }\end{array}$} & \multirow[t]{2}{*}{$\begin{array}{l}\text { Characterization } \\
\text { of Mutations: }\end{array}$} & \multirow{2}{*}{$\begin{array}{l}\text { Treatment } \\
\text { Summary: }\end{array}$} \\
\hline Gender & Age & Source & & & & & \\
\hline Female & 90 & Rectum & $\begin{array}{c}\text { Bx: } \\
\text { Grade } 2 \\
\text { Resection: } \\
\text { Grade 2 }\end{array}$ & $\begin{array}{c}\text { Not } \\
\text { staged }\end{array}$ & $\begin{array}{l}\text { Cancer- } \\
\text { related }\end{array}$ & $\begin{array}{l}\text { Biopsy and } \\
\text { Resection: } \\
\text { MMR protein } \\
\text { markers (IHC): } \\
\text { intact in bx and } \\
\text { resection. } \\
\text { PDL-1 } \\
\text { Expression- no } \\
\text { expression in bx } \\
\text { or resection. } \\
\text { BRAF mutation } \\
\text { (IHC)- no } \\
\text { expression in bx } \\
\text { or resection. } \\
\text { BRAF/ NRAS } \\
\text { mutation (PCR)- } \\
\text { no mutation } \\
\text { detected in bx or } \\
\text { resection. } \\
\text { KRAS mutation } \\
\text { (PCR)- G12X } \\
\text { mutation detected } \\
\text { in bx and } \\
\text { resection. } \\
\text { PIK3CA } \\
\text { mutation (PCR)- } \\
\text { no mutation } \\
\text { detected in bx or } \\
\text { resection. } \\
\text { res }\end{array}$ & $\begin{array}{l}\text { Biopsy, } \\
\text { local tumor } \\
\text { excision } \\
\text { and } \\
\text { fulguration } \\
\text { rectal } \\
\text { lesion. } \\
\text { Radiation } \\
\text { Perirectal } \\
\text { Region }\end{array}$ \\
\hline
\end{tabular}




\section{A.55 Diversity of Mutations and Clinicopathological Features in Patients with Recurrent Malignancies (continued).}

Table A.15. Diversity of Mutations and Clinicopathological Features in Patients with Recurrent Malignancies (continued)

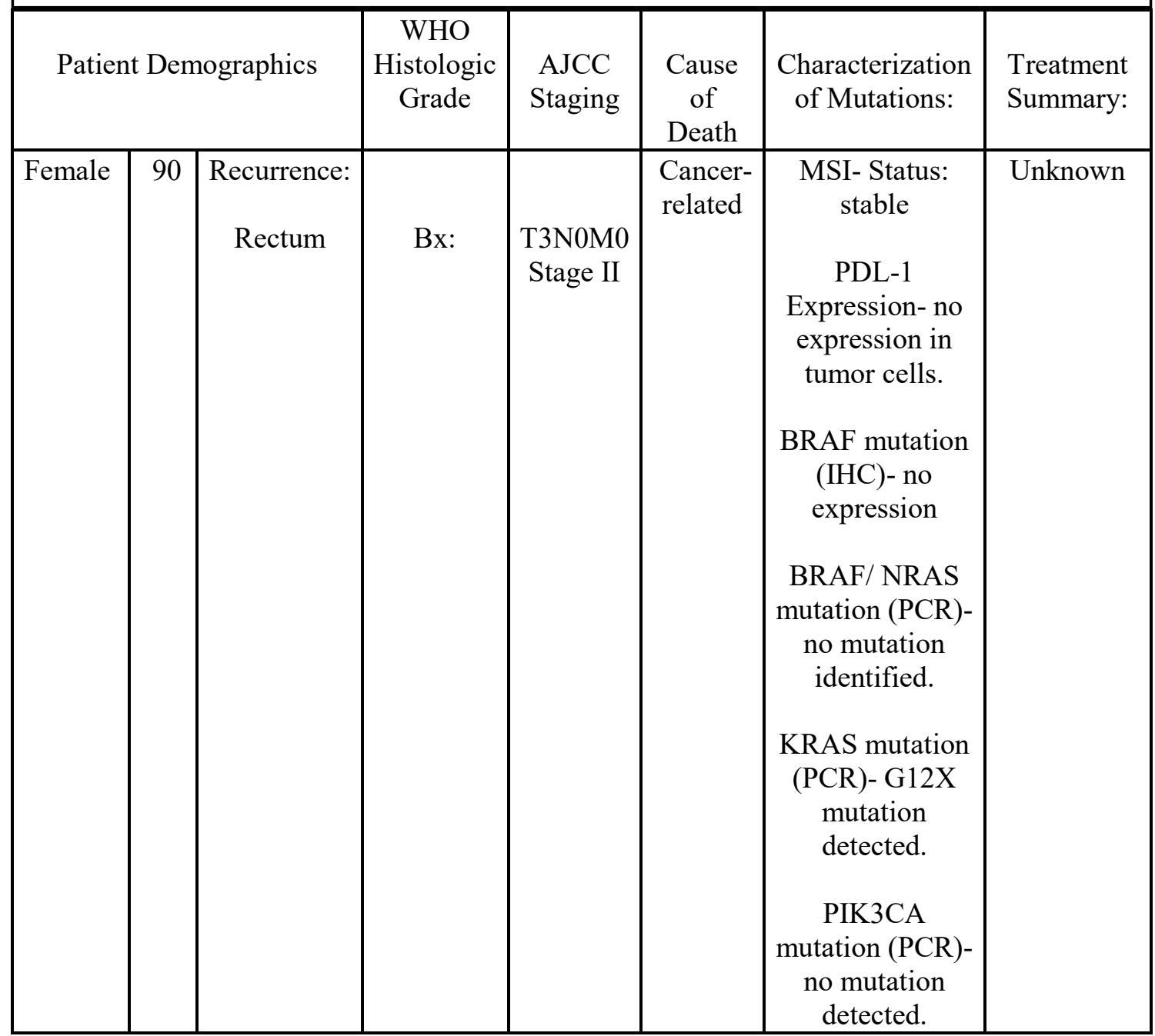




\section{A.56 Diversity of Mutations and Clinicopathological Features in Patients with Recurrent Malignancies.}

\section{Table A.15. Diversity of Mutations and Clinicopathological Features in Patients with Recurrent Malignancies (continued)}

\begin{tabular}{|c|c|c|c|c|c|c|c|}
\hline \multicolumn{3}{|c|}{ Patient Demographics } & $\begin{array}{l}\text { WHO } \\
\text { Grade }\end{array}$ & $\begin{array}{l}\text { AJCC } \\
\text { Stage }\end{array}$ & $\begin{array}{c}\begin{array}{c}\text { Cause } \\
\text { of Death }\end{array} \\
\text { Cancer- } \\
\text { related }\end{array}$ & $\begin{array}{c}\text { Characterization of } \\
\text { Mutations: } \\
\text { MMR status: } \\
\text { deficient; both } \\
\text { samples } \\
\text { demonstrated a loss } \\
\text { of MLH1/PMS2. }\end{array}$ & $\begin{array}{l}\text { Treatment } \\
\text { Summary: } \\
\text { Not avail }\end{array}$ \\
\hline Female & 80 & $\begin{array}{l}\text { Right } \\
\text { Colon }\end{array}$ & $\begin{array}{c}\text { Block } \\
\# 2- \\
\text { Grade } 2 \\
\\
\text { Block } \\
\# 6- \\
\text { Grade 1 } \\
\text { arising } \\
\text { in } \\
\text { tubular } \\
\text { adenoma }\end{array}$ & $\begin{array}{c}\text { T3N0Mx } \\
\text { Stage II } \\
\text { T1N0Mx } \\
\text { Stage I }\end{array}$ & $\begin{array}{l}\text { Cancer- } \\
\text { related }\end{array}$ & $\begin{array}{c}\text { MMR status: } \\
\text { deficient; both } \\
\text { samples } \\
\text { demonstrated a loss } \\
\text { of MLH1/PMS2. } \\
\text { PDL-1 Expression: } \\
\text { Block 2: 10-29\% } \\
\text { expression in TC. } \\
\text { Block 6: 1-9\% } \\
\text { expression in TC. } \\
\\
\text { BRAF (V600E) } \\
\text { mutation -both } \\
\text { samples were } \\
\text { positive via IHC } \\
\text { and PCR } \\
\text { KRAS mutation } \\
\text { (PCR)- no mutation } \\
\text { detected in either } \\
\text { sample. } \\
\text { PIK3CA mutation } \\
\text { (PCR)- } \\
\text { Block 2: H1047X } \\
\text { and E545X } \\
\text { mutations detected. } \\
\text { Block 6: No } \\
\text { mutation detected. }\end{array}$ & Not avail \\
\hline
\end{tabular}




\section{A.57 Diversity of Mutations and Clinicopathological Features in Patients with Recurrent Malignancies (continued).}

Table A.15. Diversity of Mutations and Clinicopathological Features in Patients with Recurrent Malignancies (continued)

\begin{tabular}{|c|c|c|c|c|c|c|c|}
\hline \multicolumn{3}{|c|}{ Patient Demographics } & $\begin{array}{c}\text { WHO } \\
\text { Grade } \\
\text { Biopsy: } \\
\text { Grade } 3\end{array}$ & $\begin{array}{c}\text { AJCC } \\
\text { Stage } \\
\text { Biopsy: } \\
\text { not staged }\end{array}$ & $\begin{array}{c}\begin{array}{c}\text { Cause } \\
\text { of } \\
\text { Death }\end{array} \\
\begin{array}{c}\text { Cancer- } \\
\text { related }\end{array}\end{array}$ & $\begin{array}{c}\begin{array}{c}\text { Characterization } \\
\text { of Mutations: }\end{array} \\
\text { MMR status: } \\
\text { deficient; both } \\
\text { samples } \\
\text { demonstrated a } \\
\text { loss of } \\
\text { MLH1/PMS2. }\end{array}$ & $\begin{array}{l}\text { Treatment } \\
\text { Summary: } \\
\text { Not avail. }\end{array}$ \\
\hline Female & 80 & $\begin{array}{l}\text { Recurrent, } \\
\text { Right } \\
\text { colon }\end{array}$ & $\begin{array}{c}\text { Biopsy: } \\
\text { Grade } 3 \\
\text { Resection: } \\
\text { Grade } 3\end{array}$ & $\begin{array}{c}\text { Biopsy: } \\
\text { not staged } \\
\text { Resection: } \\
\text { T3N0Mx } \\
\text { Stage II }\end{array}$ & $\begin{array}{c}\text { Cancer- } \\
\text { related }\end{array}$ & $\begin{array}{c}\text { MMR status: } \\
\text { deficient; both } \\
\text { samples } \\
\text { demonstrated a } \\
\text { loss of } \\
\text { MLH1/PMS2. } \\
\text { PDL-1 } \\
\text { Expression: } \\
\text { Biopsy: 1-9\% } \\
\text { expression in } \\
\text { TC. } \\
\text { Resection: 10- } \\
\text { 29\% expression } \\
\text { in TC. } \\
\text { BRAF } \\
\text { mutation: } \\
\text { Biopsy: } \\
\text { BRAFV600E } \\
\text { positive IHC; } \\
\text { Resection: } \\
\text { BRAF V600E } \\
\text { mutation } \\
\text { identified via } \\
\text { IHC and PCR } \\
\text { KRAS mutation } \\
\text { (PCR)- no } \\
\text { mutation } \\
\text { detected . } \\
\text { PIK3CA } \\
\text { mutation } \\
\text { (PCR)- no } \\
\text { mutation } \\
\text { detected. }\end{array}$ & Not avail. \\
\hline
\end{tabular}




\section{A.58 Diversity of Mutations and Clinicopathological Features in Patients with Recurrent Malignancies (continued).}

Table A.15. Diversity of Mutations and Clinicopathological Features in Patients with Recurrent Malignancies (continued)

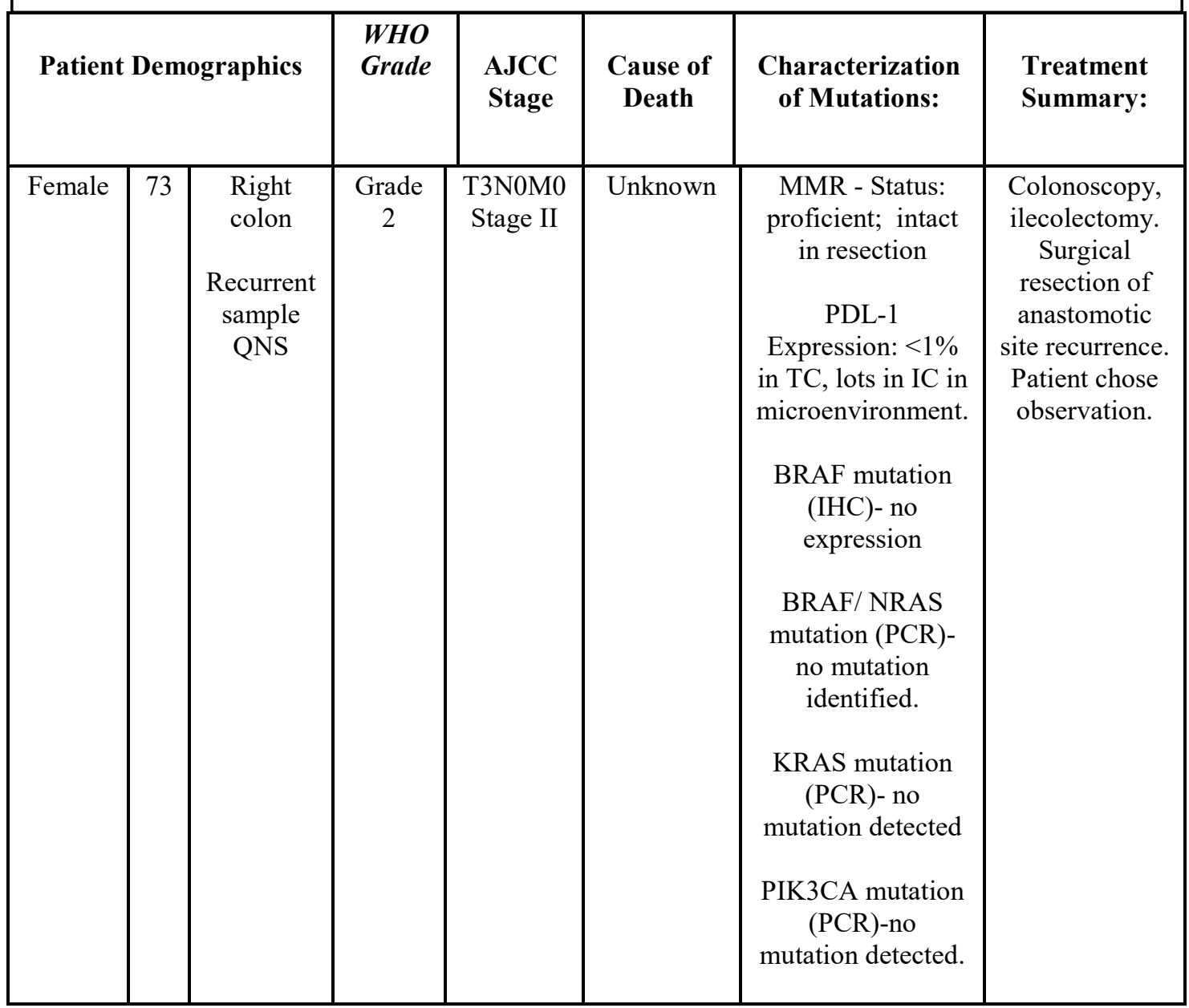




\section{A.59 Diversity of Mutations and Clinicopathological Features in Patients with Recurrent Malignancies (continued).}

Table A.15. Diversity of Mutations and Clinicopathological Features in Patients with Recurrent Malignancies (continued)

\begin{tabular}{|c|c|c|c|c|c|c|c|}
\hline \multicolumn{3}{|c|}{$\begin{array}{l}\text { Patient Demographics } \\
\text { Gender Age Source }\end{array}$} & $\begin{array}{l}\text { WHO } \\
\text { Histologic } \\
\text { Grade }\end{array}$ & $\begin{array}{l}\text { AJCC } \\
\text { Staging }\end{array}$ & $\begin{array}{l}\text { Cause } \\
\text { of } \\
\text { Death }\end{array}$ & $\begin{array}{l}\text { Characterization } \\
\text { of Mutations: }\end{array}$ & $\begin{array}{l}\text { Treatment } \\
\text { Summary: }\end{array}$ \\
\hline Female & 70 & Sigmoid & Grade 2 & $\begin{array}{l}\text { T3N2Mx } \\
\text { Stage III }\end{array}$ & $\begin{array}{l}\text { Cancer- } \\
\text { related }\end{array}$ & $\begin{array}{l}\text { MMR Status: } \\
\text { Proficient / } \\
\text { intact. } \\
\text { PDL-1 } \\
\text { Expression: } \\
\text { Colon: 1-9\% } \\
\text { expression in TC. } \\
\text { Nodes: no } \\
\text { expression in TC. } \\
\text { BRAF mutation } \\
\text { - no mutation } \\
\text { identified via } \\
\text { IHC or PCR } \\
\text { KRAS mutation } \\
\text { (PCR)- G13x } \\
\text { mutation detected } \\
\text { in both samples. } \\
\\
\text { PIK3CA } \\
\text { mutation (PCR)- } \\
\text { No mutation } \\
\text { detected in either } \\
\text { sample. }\end{array}$ & $\begin{array}{l}\text { Low } \\
\text { Anterior } \\
\text { Resection. } \\
\text { Radiation. } \\
\text { 5FU + } \\
\text { leucovorin } \\
\text { Folfox-6, } \\
\text { Avastin } \\
\text { Folfiri } \\
\text { Vectibix }\end{array}$ \\
\hline
\end{tabular}




\section{A.60 Diversity of Mutations and Clinicopathological Features in Patients with Recurrent Malignancies (continued).}

Table A.15. Diversity of Mutations and Clinicopathological Features in Patients with
Recurrent Malignancies (continued)

\begin{tabular}{|c|c|c|c|c|c|c|}
\hline \multicolumn{2}{|c|}{$\begin{array}{l}\text { Patient Demographics } \\
\text { Gender Age Source }\end{array}$} & $\begin{array}{l}\text { WHO } \\
\text { Histologic } \\
\text { Grade }\end{array}$ & $\begin{array}{l}\text { AJCC } \\
\text { Staging }\end{array}$ & $\begin{array}{l}\text { Cause } \\
\text { of } \\
\text { Death }\end{array}$ & $\begin{array}{l}\text { Characterization } \\
\text { of Mutations: }\end{array}$ & $\begin{array}{l}\text { Treatment } \\
\text { Summary: }\end{array}$ \\
\hline & $\begin{array}{l}\text { Recurrence } \\
: \\
\text { Rectum }\end{array}$ & Grade 2 & $\begin{array}{l}\text { T3N2Mx } \\
\text { Stage III }\end{array}$ & $\begin{array}{l}\text { Cancer- } \\
\text { related }\end{array}$ & $\begin{array}{l}\text { MMR Status: } \\
\text { Proficient / } \\
\text { intact. } \\
\text { PDL-1 } \\
\text { Expression: } \\
\text { No expression in } \\
\text { TC in rectum or } \\
\text { sacrum. } \\
\text { BRAF mutation } \\
\text { - no mutation } \\
\text { identified via } \\
\text { IHC or PCR } \\
\text { KRAS mutation } \\
\text { (PCR)- G13x } \\
\text { mutation } \\
\text { detected. } \\
\text { PIK3CA } \\
\text { mutation (PCR)- } \\
\text { No mutation } \\
\text { detected. }\end{array}$ & $\begin{array}{l}\text { Not } \\
\text { available. }\end{array}$ \\
\hline & $\begin{array}{l}\text { Recurrence } \\
\text { : Rectum }\end{array}$ & Grade 2 & $\begin{array}{l}\text { Refers to } \\
\text { original } \\
\text { staging }\end{array}$ & & $\begin{array}{l}\text { MMR Status: } \\
\text { Proficient / } \\
\text { intact. } \\
\text { KRAS mutation: } \\
\text { G13x mutation } \\
\text { detected. }\end{array}$ & $\begin{array}{l}\text { Not } \\
\text { available. }\end{array}$ \\
\hline
\end{tabular}




\section{A.61 Characterization of Chemoresistant Malignancies.}

Table A.16. Characterization of Chemoresistant Malignancies.

Chemoresistance was presumed based on multiple courses of cytotoxic therapies and treatment notes. Malignancies arising in the rectum were the most frequent source of chemoresistant tumors in our cohort, however, this finding is not generalizable due to the small number of samples in this category.

\begin{tabular}{|c|c|c|c|c|c|c|c|}
\hline \multicolumn{3}{|c|}{$\begin{array}{l}\text { Patient } \\
\text { Demographics }\end{array}$} & \multirow{2}{*}{$\begin{array}{l}\text { WHO } \\
\text { Grade } \\
\text { Grade } \\
3 \\
\end{array}$} & \multirow{2}{*}{$\begin{array}{l}\begin{array}{l}\text { AJCC } \\
\text { Stage }\end{array} \\
\text { T2N M0 } \\
\text { Stage III }\end{array}$} & \multirow{2}{*}{$\begin{array}{l}\begin{array}{l}\text { Cause of } \\
\text { Death }\end{array} \\
\text { Unknown }\end{array}$} & \multirow[b]{2}{*}{$\begin{array}{l}\text { Characterization } \\
\text { of Mutations: } \\
\text { MMR IHC: } \\
\text { Intact in Bx, } \\
\text { resection and } \\
\text { nodes. } \\
\text { PDL-1 } \\
\text { Expression: no } \\
\text { expression in bx, } \\
\text { resection or } \\
\text { nodes. } \\
\text { BRAF mutation } \\
\text { (IHC)- no } \\
\text { expression in bx, } \\
\text { resection or } \\
\text { nodes. } \\
\text { BRAF/ NRAS } \\
\text { mutation (PCR)- } \\
\text { no mutation } \\
\text { identified in bx; } \\
\text { resection } \\
\text { KRAS mutation } \\
\text { (PCR)- no } \\
\text { mutation } \\
\text { identified in bx; } \\
\text { resection } \\
\text { PIK3CA } \\
\text { mutation (PCR)- } \\
\text { no mutation } \\
\text { identified in bx; } \\
\text { resection. }\end{array}$} & \multirow[b]{2}{*}{$\begin{array}{l}\text { Treatment } \\
\text { Summary: } \\
\text { Surgical } \\
\text { Intervention: } \\
\text { Colonscopy w/ } \\
\text { biopsies and } \\
\text { Low anterior } \\
\text { resection } \\
\text { Chemotherapy } \\
\text { and Radiation: } \\
\text { Folfox, } \\
\text { Avastin; } \\
\text { radiation } \\
\text { Folfiri, } \\
\text { Avastin, } \\
\text { Radiation } \\
\text { Folfiri, Eribitux } \\
\text { Radiation - } \\
\text { thoracic spine. } \\
\text { Samarium } \\
\text { Erbitux, Xeloda }\end{array}$} \\
\hline Male & 46 & Rectum & & & & & \\
\hline
\end{tabular}




\section{A.62 Characterization of Chemoresistant Malignancies (continued).}

Table A.16. Characterization of Chemoresistant Malignancies (Continued).

\begin{tabular}{|c|c|c|c|c|c|c|c|}
\hline \multicolumn{3}{|c|}{$\begin{array}{l}\text { Patient } \\
\text { Demographics }\end{array}$} & $\begin{array}{l}\text { WHO } \\
\text { Grade }\end{array}$ & $\begin{array}{l}\text { AJCC } \\
\text { Stage } \\
\end{array}$ & $\begin{array}{l}\text { Cause } \\
\text { of } \\
\text { Death }\end{array}$ & $\begin{array}{l}\text { Characterization } \\
\text { of Mutations: }\end{array}$ & $\begin{array}{l}\text { Treatment } \\
\text { Summary: }\end{array}$ \\
\hline Female & 65 & Rectum & $\begin{array}{l}\text { Grade } \\
2\end{array}$ & $\begin{array}{l}\text { T3 N1 M0 } \\
\text { Stage III }\end{array}$ & $\begin{array}{l}\text { Cancer- } \\
\text { related }\end{array}$ & $\begin{array}{l}\text { MMR proteins } \\
\text { (IHC): } \\
\text { Intact in bx, } \\
\text { resection and } \\
\text { Nodes } \\
\text { PDL-1 } \\
\text { Expression- no } \\
\text { expression in bx, } \\
\text { resection or } \\
\text { nodes. } \\
\text { BRAF mutation } \\
\text { (IHC)- no } \\
\text { expression in bx, } \\
\text { resection or } \\
\text { nodes. } \\
\text { BRAF/ NRAS } \\
\text { mutation (PCR)- } \\
\text { no mutation } \\
\text { detected in bx; } \\
\text { resection and } \\
\text { nodes yielded } \\
\text { invalid results. } \\
\text { KRAS mutation } \\
\text { (PCR)- no } \\
\text { mutation detected } \\
\text { in bx; resection } \\
\text { and nodes yielded } \\
\text { invalid results. } \\
\text { PIK3CA mutation } \\
\text { (PCR)- no } \\
\text { mutation detected } \\
\text { in bx or resection; } \\
\text { nodes yielded } \\
\text { invalid results. }\end{array}$ & $\begin{array}{l}\text { Surgical } \\
\text { Intervention: } \\
\text { Colonoscopy } \\
\text { \& biopsies } \\
\text { Low Anterior } \\
\text { Resection } \\
\text { Chemotherapy } \\
\text { and Radiation: } \\
\text { 5FU \& } \\
\text { leucorvorin } \\
\text { Folfox-6 \& } \\
\text { Avastin } \\
\text { Radioactive } \\
\text { sir-spheres }\end{array}$ \\
\hline
\end{tabular}




\section{A.63 Characterization of Chemoresistant Malignancies (continued).}

Table A.16. Characterization of Chemoresistant Malignancies (continued).

\begin{tabular}{|c|c|c|c|c|c|c|c|}
\hline \multicolumn{3}{|c|}{$\begin{array}{l}\text { Patient } \\
\text { Demographics } \\
\text { Gender Age Source }\end{array}$} & $\begin{array}{l}\text { WHO } \\
\text { Grade }\end{array}$ & $\begin{array}{l}\text { AJCC } \\
\text { Stage }\end{array}$ & $\begin{array}{l}\text { Cause of } \\
\text { Death }\end{array}$ & $\begin{array}{l}\text { Summary of } \\
\text { Mutations: }\end{array}$ & $\begin{array}{l}\text { Treatment } \\
\text { Summary: }\end{array}$ \\
\hline Female & 45 & sigmoid & $\begin{array}{l}\text { Grade } \\
2\end{array}$ & $\begin{array}{l}\text { T3N1M0 } \\
\text { Stage III }\end{array}$ & Unknown & $\begin{array}{l}\text { MMR proteins: } \\
\text { Intact in bx, } \\
\text { resection and } \\
\text { nodes. } \\
\text { PDL-1 } \\
\text { Expression- no } \\
\text { expression in } \\
\text { bx, resection or } \\
\text { nodes. } \\
\text { BRAF mutation } \\
\text { (IHC)- no } \\
\text { expression in } \\
\text { bx, resection or } \\
\text { nodes. } \\
\text { BRAF/ NRAS } \\
\text { mutation (PCR)- } \\
\text { no mutation } \\
\text { identified in } \\
\text { resection. } \\
\text { KRAS mutation } \\
\text { (PCR)- G13X } \\
\text { identified in } \\
\text { colon resection } \\
\text { but not in nodes. } \\
\text { PIK3CA } \\
\text { mutation (PCR)- } \\
\text { no mutation } \\
\text { identified. }\end{array}$ & $\begin{array}{l}\text { Surgical } \\
\text { Intervention: } \\
\text { Colonoscopy } \\
\text { Segmental } \\
\text { resection } \\
\text { Chemotherapy } \\
\text { and } \\
\text { radiotherapy: } \\
\text { Folfox } \\
\text { Radio- } \\
\text { frequency } \\
\text { ablation: liver } \\
\text { mets, } \\
\text { Folfox- } 4 \\
\text { Xeloda / } \\
\text { Avastin }\end{array}$ \\
\hline
\end{tabular}




\section{A.64 Characterization of Chemoresistant Malignancies (continued).}

Table A.16. Characterization of Chemoresistant Malignancies (continued).

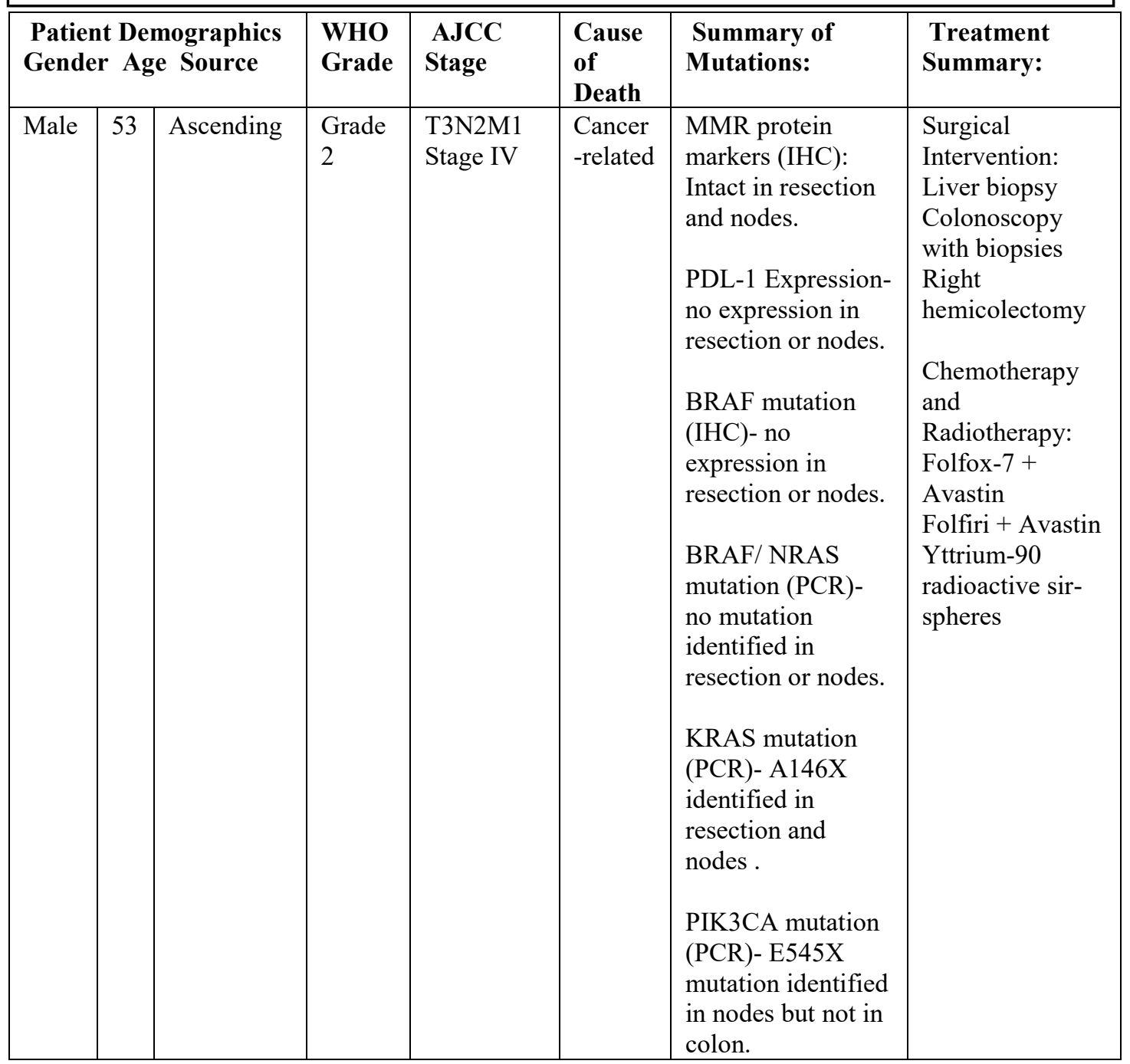




\section{A.65 Characterization of Chemoresistant Malignancies (continued).}

Table A.16. Characterization of Chemoresistant Malignancies (continued).

\begin{tabular}{|c|c|c|c|c|c|c|c|}
\hline \multicolumn{3}{|c|}{$\begin{array}{l}\text { Patient Demographics } \\
\text { Gender Age Source }\end{array}$} & $\begin{array}{l}\text { WHO } \\
\text { Grade }\end{array}$ & $\begin{array}{l}\text { AJCC } \\
\text { Stage }\end{array}$ & $\begin{array}{l}\text { Cause of } \\
\text { Death }\end{array}$ & $\begin{array}{l}\text { Characterization } \\
\text { of Mutations: }\end{array}$ & $\begin{array}{l}\text { Treatment } \\
\text { Summary: }\end{array}$ \\
\hline Female & 70 & $\begin{array}{l}\text { Overlapping } \\
\text { lesion }\end{array}$ & $\begin{array}{l}\text { Grade } \\
2\end{array}$ & $\begin{array}{l}\text { T3 N1 } \\
\text { M0 } \\
\text { Stage } \\
\text { III }\end{array}$ & Deceased & $\begin{array}{l}\text { MMR proteins } \\
\text { (IHC): Intact in } \\
\text { bx, resection and } \\
\text { nodes. } \\
\text { PDL-1 } \\
\text { Expression- no } \\
\text { expression in bx, } \\
\text { resection or } \\
\text { nodes. } \\
\text { BRAF mutation } \\
\text { (IHC)- no } \\
\text { expression in bx, } \\
\text { resection or } \\
\text { nodes. } \\
\text { BRAF/ NRAS } \\
\text { mutation (PCR)- } \\
\text { no mutation } \\
\text { detected in bx, } \\
\text { resection or } \\
\text { nodes. } \\
\text { KRAS mutation } \\
\text { (PCR)- no } \\
\text { mutation detected } \\
\text { in bx, resection or } \\
\text { nodes. } \\
\text { PIK3CA } \\
\text { mutation (PCR)- } \\
\text { no mutation } \\
\text { detected in bx, } \\
\text { resection or } \\
\text { nodes. }\end{array}$ & $\begin{array}{l}\text { Surgical } \\
\text { Intervention: } \\
\text { Biopsy } \\
\text { Ileocolectomy } \\
\text { Chemotherapy } \\
\text { Regimen: } \\
\text { Folfox } \\
\text { Folfiri + } \\
\text { Avastin } \\
\text { 5FU, } \\
\text { Irinotecan, } \\
\text { Avastin } \\
\text { Xeloda }\end{array}$ \\
\hline
\end{tabular}




\section{A.66 Characterization of Chemoresistant Malignancies (continued).}

Table A.16. Characterization of Chemoresistant Malignancies (continued).

\begin{tabular}{|c|c|c|c|c|c|c|c|}
\hline \multicolumn{3}{|c|}{$\begin{array}{l}\text { Patient Demographics } \\
\text { Gender Age Source }\end{array}$} & $\begin{array}{l}\text { Grade } \\
\text { Grade } \\
3\end{array}$ & $\begin{array}{l}\text { AJCC } \\
\text { Stage } \\
\text { T3 N0 } \\
\text { M0 } \\
\text { Stage } \\
\text { II }\end{array}$ & $\begin{array}{l}\text { of } \\
\text { Death } \\
\text { Not } \\
\text { cancer- } \\
\text { related }\end{array}$ & $\begin{array}{l}\begin{array}{l}\text { Characterization } \\
\text { of Mutations: }\end{array} \\
\text { MMR protein } \\
\text { markers (IHC): } \\
\text { Intact. }\end{array}$ & $\begin{array}{l}\text { Treatment } \\
\text { Summary: } \\
\text { Surgical } \\
\text { intervention: } \\
\text { Colonoscopy } \\
\text { Colon Resection }\end{array}$ \\
\hline Female & 69 & Transverse & $\begin{array}{l}\text { Grade } \\
3\end{array}$ & $\begin{array}{l}\text { T3 N0 } \\
\text { M0 } \\
\text { Stage } \\
\text { II }\end{array}$ & $\begin{array}{l}\text { Not } \\
\text { cancer- } \\
\text { related }\end{array}$ & $\begin{array}{l}\text { MMR protein } \\
\text { markers (IHC): } \\
\text { Intact. } \\
\text { PDL-1 } \\
\text { Expression- No } \\
\text { expression. } \\
\text { BRAF mutation } \\
\text { (IHC)- no } \\
\text { expression } \\
\text { present. } \\
\text { BRAF/ NRAS } \\
\text { mutation (PCR)- } \\
\text { no mutation } \\
\text { detected. } \\
\text { KRAS mutation } \\
\text { (PCR)- G12X } \\
\text { mutation } \\
\text { detected. } \\
\text { PIK3CA } \\
\text { mutation (PCR)- } \\
\text { no mutation } \\
\text { detected. }\end{array}$ & $\begin{array}{l}\text { Surgical } \\
\text { intervention: } \\
\text { Colonoscopy } \\
\text { Colon Resection } \\
\text { Chemotherapeutic } \\
\text { regimen: } \\
\text { 5FU and } \\
\text { Leucovorin } \\
\text { Observation }\end{array}$ \\
\hline
\end{tabular}




\section{A.67 Characterization of Chemoresistant Malignancies (continued).}

Table A.16. Characterization of Chemoresistant Malignancies (continued).

\begin{tabular}{|c|c|c|c|c|c|c|c|}
\hline \multicolumn{3}{|c|}{$\begin{array}{l}\text { Patient } \\
\text { Demographics } \\
\text { Gender Age Source }\end{array}$} & $\begin{array}{l}\text { WHO } \\
\text { Grade }\end{array}$ & $\begin{array}{l}\text { AJCC } \\
\text { Stage }\end{array}$ & $\begin{array}{l}\text { Cause of } \\
\text { Death }\end{array}$ & $\begin{array}{l}\text { Characterization } \\
\text { of Mutations: }\end{array}$ & $\begin{array}{l}\text { Treatment } \\
\text { Summary: }\end{array}$ \\
\hline Male & 53 & $\begin{array}{l}\text { Right } \\
\text { colon }\end{array}$ & Grade 2 & $\begin{array}{l}\text { T3 N0 M0 } \\
\text { Stage II }\end{array}$ & $\begin{array}{l}\text { Not } \\
\text { applicable }\end{array}$ & 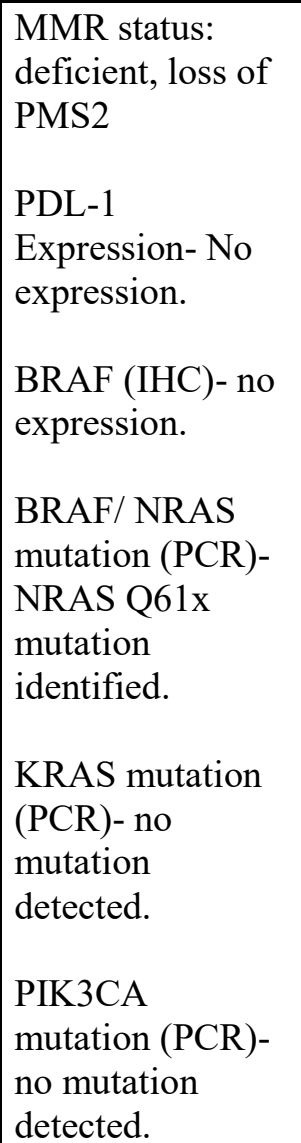 & $\begin{array}{l}\text { Surgical } \\
\text { Intervention: } \\
\text { Colonoscopy/ } \\
\text { EGD Bx } \\
\text { Colectomy } \\
\text { Resection of liver } \\
\text { mets } \\
\text { Chemotherapeutic } \\
\text { Regimen: } \\
\text { Observation } \\
\text { Folfox + Avastin } \\
\text { Folfiri }\end{array}$ \\
\hline
\end{tabular}




\section{A.68 Characterization of Chemoresistant Malignancies (continued).}

Table A.16. Characterization of Chemoresistant Malignancies (continued).

\begin{tabular}{|c|c|c|c|c|c|c|c|}
\hline \multicolumn{3}{|c|}{$\begin{array}{l}\text { Demographics } \\
\text { Gender Age Source }\end{array}$} & Grade & $\begin{array}{l}\text { AJCC } \\
\text { Stage }\end{array}$ & Death & $\begin{array}{l}\text { Characterization } \\
\text { of Mutations: }\end{array}$ & $\begin{array}{l}\text { Treatment } \\
\text { Summary: }\end{array}$ \\
\hline Male & 51 & Colon & Grade 2 & $\begin{array}{l}\text { T3N0M0 } \\
\text { Stage II }\end{array}$ & $\begin{array}{l}\text { Cancer- } \\
\text { related }\end{array}$ & $\begin{array}{l}\text { MMR - Status: } \\
\text { intact in } \\
\text { resection } \\
\text { PDL-1 } \\
\text { Expression- } \\
<1 \% \text { expression } \\
\text { in tumor cells. } \\
\text { BRAF mutation } \\
\text { (IHC)- no } \\
\text { expression } \\
\text { BRAF/ NRAS } \\
\text { mutation } \\
\text { (PCR)- no } \\
\text { mutation } \\
\text { detected. } \\
\text { KRAS mutation } \\
\text { (PCR)- no } \\
\text { mutation } \\
\text { detected. } \\
\text { PIK3CA } \\
\text { mutation } \\
\text { (PCR)- no } \\
\text { mutation } \\
\text { detected. }\end{array}$ & $\begin{array}{l}\text { Surgical } \\
\text { Intervention: } \\
\text { appendectomy } \\
\text { and } \\
\text { ileocolectomy } \\
\\
\text { Chemotherapeutic } \\
\text { Regimen: } \\
\text { Xeloda } \\
\text { Folfox } \\
\text { Folfiri, Avastin } \\
\text { Irinotecan, } \\
\text { Erbitux } \\
\text { Xelox, Avastin }\end{array}$ \\
\hline
\end{tabular}




\section{A.69 Clinicopathological Features of Malignancies in Which No Mutations Were Detected.}

Table A.17. Clinicopathological Features of Malignancies in Which No Mutations Were Detected. No mutations were detected in a subset of samples in this study. Of these, a majority of the primary tumors arose in the rectum and belonged to males.

\begin{tabular}{|l|l|l|l|l|l|}
\hline \multicolumn{2}{|l|}{ Patient Demographics } & $\begin{array}{l}\text { WHO } \\
\text { Histologic } \\
\text { Grade }\end{array}$ & $\begin{array}{l}\text { AJCC } \\
\text { Staging }\end{array}$ & $\begin{array}{l}\text { Cause of } \\
\text { Death }\end{array}$ \\
\hline Source & Gender & Age & & & \\
\hline Rectum & Male & 46 & Grade 3 & T2N0M0 & Unknown \\
\hline $\begin{array}{l}\text { Hepatic } \\
\text { Flexure }\end{array}$ & Female & 65 & Grade 2 & T3N0M0 & $\begin{array}{l}\text { Cancer } \\
\text { related }\end{array}$ \\
\hline Rectum & Male & 78 & & & T3N \\
\hline Rectum & Female & 65 & Grade 2 & T3N1M0 & $\begin{array}{l}\text { Cancer- } \\
\text { related }\end{array}$ \\
\hline Rectum & Male & 78 & Grade 3 & T3N2M0 & $\begin{array}{l}\text { Cancer- } \\
\text { related }\end{array}$ \\
\hline $\begin{array}{l}\text { Overlapping } \\
\text { Lesion }\end{array}$ & Female & 70 & Grade 2 & T3N1M0 & $\begin{array}{l}\text { Cancer- } \\
\text { related }\end{array}$ \\
\hline Rectum & Male & 83 & Grade 3 & T3N2M0 & Unknown \\
\hline Rectum & Male & 68 & Grade 2 & T1N0M0 & Unknown \\
\hline Rectum & Male & 76 & Grade 2 & T3N0M0 & $\begin{array}{l}\text { Not } \\
\text { applicable }\end{array}$ \\
\hline Sigmoid & Male & 78 & Grade 2 & T3N0M0 & $\begin{array}{l}\text { Cancer- } \\
\text { related }\end{array}$ \\
\hline Transverse & Male & 82 & Grade 2 & T4N0M0 & $\begin{array}{l}\text { Cancer- } \\
\text { related }\end{array}$ \\
\hline Male & Rectum & 55 & Grade 2 & T2N0M0 & Unknown \\
\hline Male & Rectum & 56 & Grade2 & T3NxMx & $\begin{array}{l}\text { Cancer- } \\
\text { related }\end{array}$ \\
\hline
\end{tabular}




\section{A.70 Clinicopathological Features of Malignancies in Which No Mutations Were Detected (continued).}

\begin{tabular}{|c|c|c|c|c|c|}
\hline \multicolumn{6}{|c|}{$\begin{array}{l}\text { Table A.17. Clinicopatholo } \\
\text { in Which No Mutations We }\end{array}$} \\
\hline \multicolumn{3}{|c|}{ Patient Demographics } & \multirow{2}{*}{\begin{tabular}{|l|} 
WHO \\
Histologic \\
Grade
\end{tabular}} & \multirow{2}{*}{$\begin{array}{l}\text { AJCC } \\
\text { Staging } \\
\end{array}$} & \multirow{2}{*}{$\begin{array}{l}\text { Cause of } \\
\text { Death }\end{array}$} \\
\hline \begin{tabular}{|l|} 
Source \\
\end{tabular} & Gender & Age & & & \\
\hline Male & Sigmoid & 56 & Grade 2 & T2N0M0 & $\begin{array}{l}\text { Not } \\
\text { cancer- } \\
\text { related }\end{array}$ \\
\hline Rectum & Male & 33 & Grade 2 & T2N0M0 & Unknown \\
\hline Rectum & Female & 65 & Grade 2 & T3N0M0 & $\begin{array}{l}\text { Cancer- } \\
\text { related }\end{array}$ \\
\hline Transverse & Male & 72 & Grade 2 & T3N0M0 & $\begin{array}{l}\text { Not } \\
\text { cancer- } \\
\text { related }\end{array}$ \\
\hline Ascending & Female & 66 & Grade 2 & T1N0M0 & Unknown \\
\hline \begin{tabular}{|l|} 
Sigmoid \\
\end{tabular} & Male & 80 & Grade 2 & T3N0M0 & \\
\hline Cecum & Male & 83 & Grade 3 & T1N0M0 & $\begin{array}{l}\text { Cancer- } \\
\text { related }\end{array}$ \\
\hline $\begin{array}{l}\text { Hepatic } \\
\text { flexure }\end{array}$ & Female & 66 & Grade 2 & T3N0M0 & \\
\hline Right colon & Male & 68 & Grade 2 & T1N0M0 & $\begin{array}{l}\text { Not } \\
\text { cancer- } \\
\text { related }\end{array}$ \\
\hline Rectum & Male & 73 & Grade 2 & T3N0M0 & Unknown \\
\hline $\begin{array}{l}\text { Hepatic } \\
\text { flexure }\end{array}$ & Male & 52 & Grade 2 & T3N0M0 & Unknown \\
\hline Sigmoid & Male & 58 & Grade 1 & T1N0M0 & $\begin{array}{l}\text { Not } \\
\text { cancer- } \\
\text { related }\end{array}$ \\
\hline Sigmoid & Male & 74 & $\begin{array}{l}\text { Grade } 2 \\
\text { for synch } \\
\text { malig x } 2 \\
\text { and } \\
\text { resection }\end{array}$ & $\begin{array}{l}\text { Synch= } \\
\text { TisNxMx } \\
\text { Resection= } \\
\text { T1N0Mx }\end{array}$ & Unknown \\
\hline Cecum & Male & 83 & Grade 2 & T2N0M0 & Unknown \\
\hline
\end{tabular}




\section{A.71 Clinicopathological Features of Patients Who Died From Cancer-Related Causes.}

\section{Table A.18. Clinicopathological Features of Patients Who Died From}

Cancer-Related Causes. Thirty-seven percent of the patients in this cohort expired due to cancer-related causes. Interestingly, $57 \%$ of the patients that passed away were originally diagnosed with localized disease (white rows) or synchronous malignancies (green rows) vs. those originally diagnosed with metastatic disease (yellow rows). Over $40 \%$ of the patients who passed away from $\mathrm{CRC}$ had primary tumors arising in the proximal colon.

\begin{tabular}{|c|c|c|c|}
\hline \multicolumn{4}{|c|}{ Summary of Patients With Cancer-Related Cause of Death } \\
\hline Sex of Patient & $\begin{array}{c}\text { Age of Patient } \\
\text { (years) }\end{array}$ & Location of Originating Malignancy & $\begin{array}{l}\text { Classification of Tumor } \\
\text { (Right vs. Left Colon) }\end{array}$ \\
\hline Male & 69 & Sigmoid & Left \\
\hline Male & 70 & Cecum & Right \\
\hline Female & 66 & Transverse & Transverse \\
\hline Male & 78 & Rectum & Rectum \\
\hline Female & 65 & Rectum & rectum \\
\hline Female & 71 & Cecum & Right \\
\hline Male & 53 & Ascending & Right \\
\hline Male & 78 & Rectum & Rectum \\
\hline Female & 70 & Overlapping lesion & $\mathrm{N} / \mathrm{A}$ \\
\hline Male & 68 & Rectum & Rectum \\
\hline Female & 74 & Sigmoid & Left \\
\hline Female & 66 & Transverse & Transverse \\
\hline Female & 66 & Cecum & Right \\
\hline Female & 60 & Descending & Left \\
\hline Male & 81 & Ileocecal & Right \\
\hline Male & 78 & Sigmoid & Left \\
\hline Female & 82 & Sigmoid & Left \\
\hline Male & 82 & Transverse & Transverse \\
\hline Male & 83 & Right colon & Right \\
\hline Male & 68 & Sigmoid & Left \\
\hline Male & 56 & Hepatic flexure & Right \\
\hline Female & 87 & Ascending & Right \\
\hline Male & 56 & Rectum & Rectum \\
\hline Female & 86 & Ascending & Right \\
\hline Female & 69 & Descending & Left \\
\hline Female & 76 & Transverse & Transverse \\
\hline Female & 65 & Rectum & Rectum \\
\hline Male & 84 & Hepatic flexure & Right \\
\hline Male & 76 & Cecum & Right \\
\hline Male & 64 & Transverse & Transverse \\
\hline Female & 78 & Ascending & Right \\
\hline male & 75 & Transverse & Transverse \\
\hline Female & 67 & Splenic flexure & Left \\
\hline Male & 88 & Cecum & Right \\
\hline Male & 83 & Cecum & Right \\
\hline Female & 66 & Hepatic flexure & Right \\
\hline Female & 67 & Right colon & Right \\
\hline Male & 89 & Splenic flexure & Left \\
\hline Male & 51 & Colon, NOS & $\mathrm{NA}$ \\
\hline Female & 83 & Cecum & Right \\
\hline Female & 90 & Rectum & Rectum \\
\hline Female & 80 & Right colon & Right \\
\hline Female & 70 & Rectum & Sigmoid \& Rectum \\
\hline Male & 78 & Descending & Left \\
\hline
\end{tabular}




\section{B Copyright Documentation}

\section{MAYO \\ CLINIC \\ Q⿻}

October 18, 2019

Permissions: Catherine Bammert

Michigan Technological University

1400 Townsend Drive

Houghton, MI 49931-1295

To Whom It May Concern:

On behalf of Mayo Foundation for Medical Education and Research, I grant Catherine Bammert permission to reuse the attached image, for which Mayo Foundation for Medical Education and Research holds copyright, in the new work

Bammert C. Colorectal cancer in the upper peninsula of Michigan: A population-based study characterizing molecular mutations and clinical attributes (Thesis). Houghton, Michigan. Michigan Technological University, 2019.

As Copyright Agent for Mayo Foundation, I grant permission to include the aforementioned image, in print and electronic forms of the new work on the condition that credit be given as follows: "Used with permission of Mayo Foundation for Medical Education and Research, all rights reserved."

Sincerely,

Mayo Foundation for Medical Education and Research
200 First Street SW

(507) 284-3335

Scientific Publications

\section{Digtaly sgned by Kanna

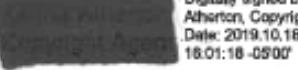

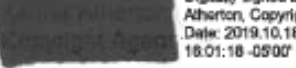 \\ Copyright Agent}




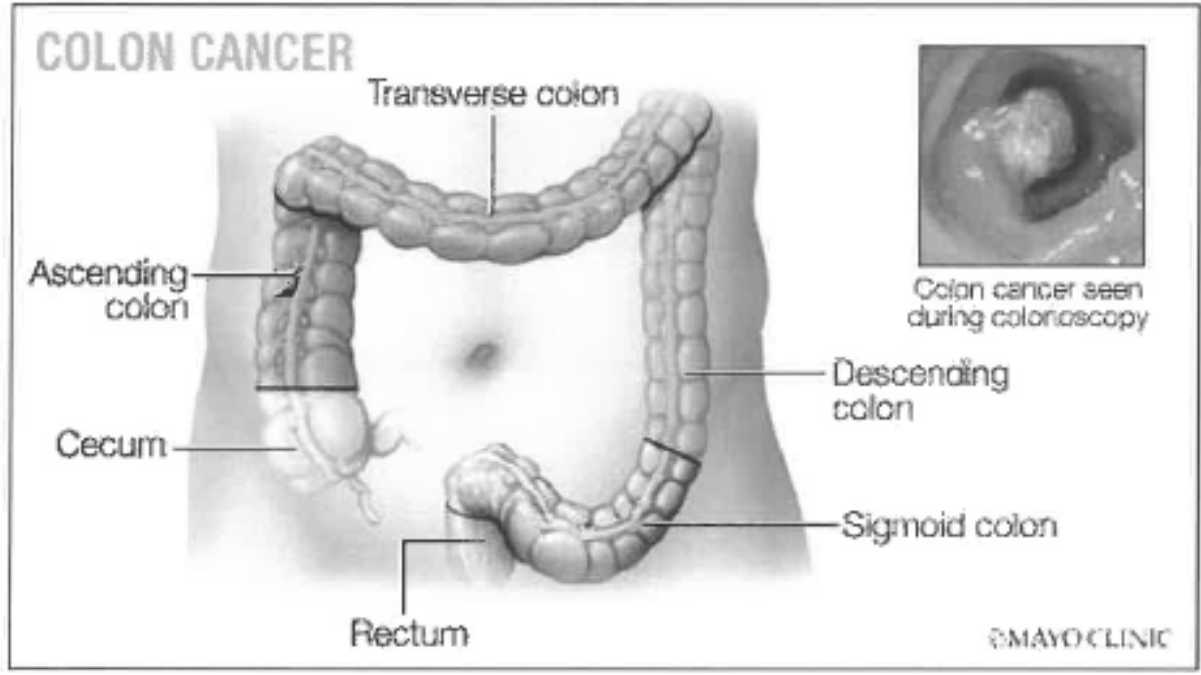

